\title{
Journal of

\section{Design and Synthesis of Neuroprotective Methylthiazoles and Modification as NO-Chimeras for Neurodegenerative Therapy}

\author{
Zhihui Qin, $^{\dagger}$ Jia Luo, $^{\dagger}$ Lawren VandeVrede, $^{\dagger}$ Ehsan Tavassoli, ${ }^{\dagger}$ Mauro Fa ${ }^{\ddagger}{ }^{\ddagger}$ Andrew F. Teich, ${ }^{\ddagger}$
} Ottavio Arancio, ${ }^{\ddagger}$ and Gregory R. J. Thatcher* ${ }^{\dagger}$ ${ }^{\dagger}$ Department of Medicinal Chemistry and Pharmacognosy, University of Illinois College of Pharmacy, University of Illinois at
Chicago, 833 S. Wood Street, Chicago, Illinois 60612-7231, United States
${ }^{\ddagger}$ Department of Pathology and Cell Biology, The Taub Institute for Research on Alzheimer's Disease and the Aging Brain, Columbia
University, 630 West 168th Street, New York, New York 10032, United States

Supporting Information

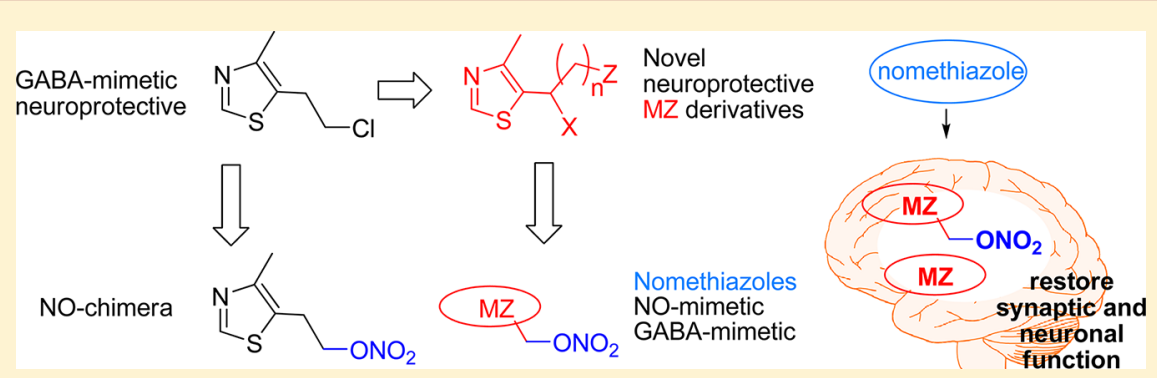

ABSTRACT: Learning and memory deficits in Alzheimer's disease (AD) result from synaptic failure and neuronal loss, the latter caused in part by excitotoxicity and oxidative stress. A therapeutic approach is described that uses NO-chimeras directed at restoration of both synaptic function and neuroprotection. 4-Methylthiazole (MZ) derivatives were synthesized, based upon a lead neuroprotective pharmacophore acting in part by $\mathrm{GABA}_{\mathrm{A}}$ receptor potentiation. $\mathrm{MZ}$ derivatives were assayed for protection of primary neurons against oxygen-glucose deprivation and excitotoxicity. Selected neuroprotective derivatives were incorporated into NO-chimera prodrugs, coined nomethiazoles. To provide proof of concept for the nomethiazole drug class, selected examples were assayed for restoration of synaptic function in hippocampal slices from $\mathrm{AD}$-transgenic mice, reversal of cognitive deficits, and brain bioavailability of the prodrug and its neuroprotective MZ metabolite. Taken together, the assay data suggest that these chimeric nomethiazoles may be of use in treatment of multiple components of neurodegenerative disorders, such as $\mathrm{AD}$.

\section{INTRODUCTION}

Alzheimer's disease $(\mathrm{AD})$ is an age-related neurodegenerative disease manifested by progressive memory loss, decline in language skills, and other cognitive impairments. The disorder is reaching epidemic proportions, with a large human, social, and economic burden. ${ }^{1}$ Currently approved treatments may temporarily reduce the rate of cognitive decline in a limited number of patients, without halting disease progression; however, no treatment is considered disease-modifying. ${ }^{2}$ Diverse factors play a role in the pathogenesis of $\mathrm{AD}$, notably abnormal aggregation of amyloid $\beta(\mathrm{A} \beta)$ and tau protein, glutamate-induced excitotoxicity, oxidative stress, and inflammation. ${ }^{3}$ Accordingly, a variety of therapeutic strategies modulating the progression or prevention of $\mathrm{AD}$ are currently being investigated. ${ }^{4,5} \mathrm{AD}$ represents a major unmet medical need.

Excitotoxicity is a mechanism of neuronal dysfunction and cell death characterized by excessive stimulation of glutamate receptors, pathological elevation of intracellular calcium concentration, and mitochondrial damage. The methylthiazole (MZ) containing GABA-mimetic agent clomethiazole (CMZ,
Scheme 1) potentiates the function of the inhibitory neurotransmitter GABA in the brain, ${ }^{6-8}$ attenuating glutamate induced excitotoxicity. CMZ has seen clinical use in a number of indications, ${ }^{9-11}$ and study of compounds related to CMZ has shown that anticonvulsant and hypnotic potency could be

Scheme 1. Design Concept for Novel Nomethiazole NOChimeras Based upon Neuroprotective MZ Scaffolds

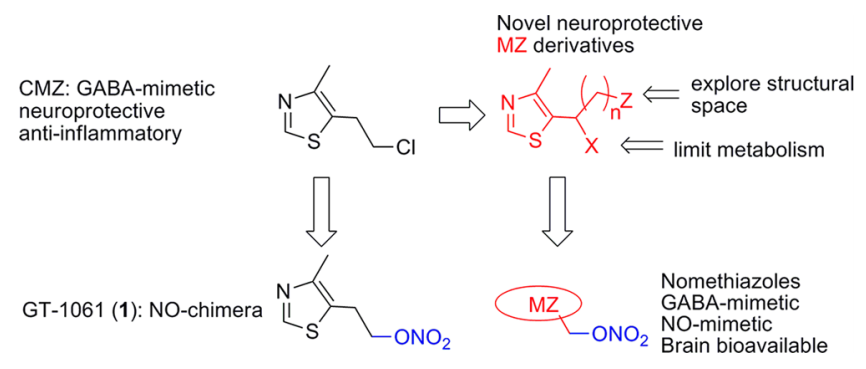

Received: March 13, 2012

Published: July 10, 2012 
Scheme $2^{a}$
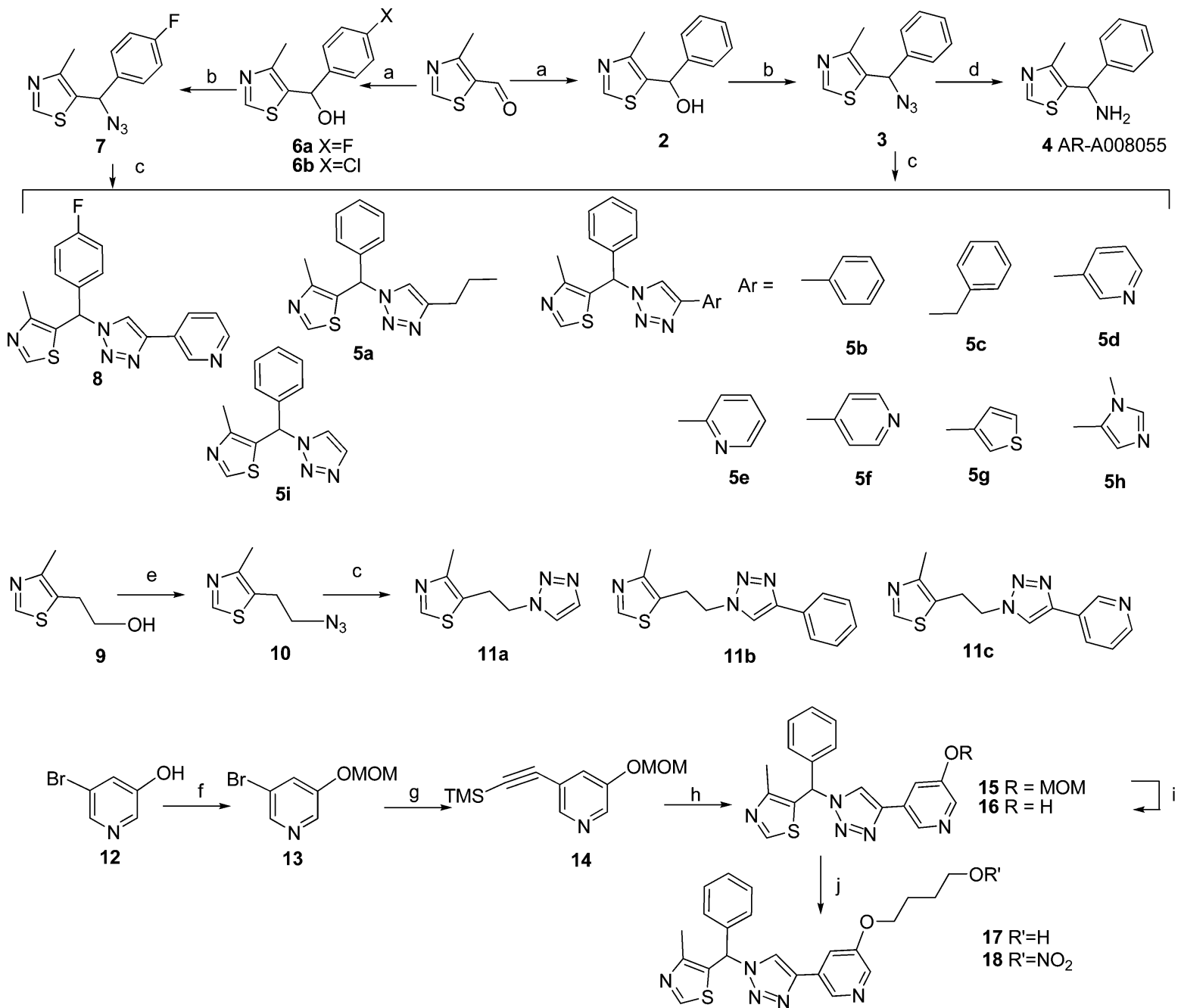

${ }^{a}$ Reagents and conditions: (a) Grignard reagent, THF, $0{ }^{\circ} \mathrm{C}$ to rt; (b) $\mathrm{MsCl}, \mathrm{NEt}_{3}$ and then $\mathrm{NaN}_{3}, \mathrm{CH}_{3} \mathrm{CN}_{\text {, rt; }}$ (c) alkyne, $\mathrm{CuSO}_{4} \cdot 5 \mathrm{H}_{2} \mathrm{O}$, sodium ascorbate, $t-\mathrm{BuOH} / \mathrm{H}_{2} \mathrm{O}(1: 1, \mathrm{v} / \mathrm{v})$; (d) $\mathrm{LiAlH}_{4}$, THF, reflux; (e) $\mathrm{MsCl}, \mathrm{NEt}_{3}$ and then $\mathrm{NaN}_{3}, \mathrm{CH}_{3} \mathrm{CN}$, reflux; (f) $\mathrm{MOM}-\mathrm{Br}_{2}, \mathrm{~K}_{2} \mathrm{CO} 3, \mathrm{THF}$; (g) ethynyltrimethylsilane, CuI, $\mathrm{Pd}\left(\mathrm{Ph}_{3} \mathrm{P}\right)_{2} \mathrm{Cl}_{2}, \mathrm{NEt}_{3}$, THF; (h) 3, $\mathrm{CuSO}_{4} \cdot 5 \mathrm{H}_{2} \mathrm{O}$, sodium ascorbate, $\mathrm{K}_{2} \mathrm{CO}_{3}, \mathrm{MeOH}-\mathrm{H}_{2} \mathrm{O}(2: 1) ;(\mathrm{i}) \mathrm{HCl} / \mathrm{i}$ - $\mathrm{PrOH}(1.5$ $\mathrm{M}), 70{ }^{\circ} \mathrm{C}$; (j) 4-nitrooxybutan-1-ol (for 18) or 1-acetoxy-4-hydroxybutane (for 17), $\mathrm{Ph}_{3} \mathrm{P}, \mathrm{DIAD}, 0{ }^{\circ} \mathrm{C}$ to rt, then $\mathrm{K}_{2} \mathrm{CO}_{3}, \mathrm{MeOH}$ (for 17 ).

dissociated and modulated separately. ${ }^{12-17}$ Under the name Zendra, CMZ was explored in clinical trials including phase III trials as a neuroprotective drug for use in spinal cord injury and ischemic stroke, ${ }^{18-25}$ and CMZ continues to be suggested as a potential component of future combination therapies for neuronal injury. ${ }^{26} \mathrm{CMZ}$ has also been demonstrated to counteract inflammation, lowering levels of proinflammatory cytokines, including $\mathrm{TNF} \alpha{ }^{27,28}$ and to rescue mitochondrial function in brain tissues. ${ }^{29}$ Recent evidence, from both clinical observations and mouse model studies, supports $\operatorname{TNF} \alpha$ as a therapeutic target in $\mathrm{AD} .^{30-32}$ Likewise, restoration of mictochondrial function is seen as a strategy for $\mathrm{AD}$ therapy. ${ }^{33,34}$ Therefore, MZ derivatives, capable of eliciting neuroprotection and attenuating neuroinflammation, are of potential clinical utility in $\mathrm{AD}$.

An early event in $\mathrm{AD}$ is synaptic failure. ${ }^{35}$ Restoration of synaptic function via activation of cAMP-responsive element binding factor (CREB) is seen as a new target for treatment of $\mathrm{AD}$ and other neurological disorders. ${ }^{36-43}$ Activation of CREB is known to enhance or restore long-term potentiation (LTP) and the expression of corresponding gene products to enhance neuronal plasticity and neurogenesis. ${ }^{44-46}$ Since activation of CREB in the hippocampus is tightly coupled to NO/cGMP signaling, ${ }^{44,46-49}$ restoration of normal NO/cGMP signaling in the aging brain is essential to preserve both synaptic and neuronal survival and function. NO-mimetic agents that enhance CREB activity will likely be of benefit in treatment of $\mathrm{AD} .^{50}$

We have previously reported a chimeric molecule with NO and GABA-mimetic attributes, 1 (GT-1061), that contains an MZ pharmacophore (Scheme 1). ${ }^{50} 1$ significantly improved learning and memory in rats with cognitive deficits in the cholinergic systems of the basal forebrain. ${ }^{37}$ A key objective of the present study was to determine if $\mathbf{1}$ is a prototype of an NO-chimera drug class. A positive observation would allow further optimization and refinement of this drug class for $\mathrm{AD}$ and other CNS indications. We report herein (1) the development of a small MZ library, (2) selection of MZ derivatives based upon neuroprotective activity screened in primary neurons, (3) synthesis of novel NO-chimeras, coined nomethiazoles, (4) selection based upon chemical stability, (5) assay for synaptic rescue in brain slices, (6) assay for restoration 
Scheme $3^{a}$

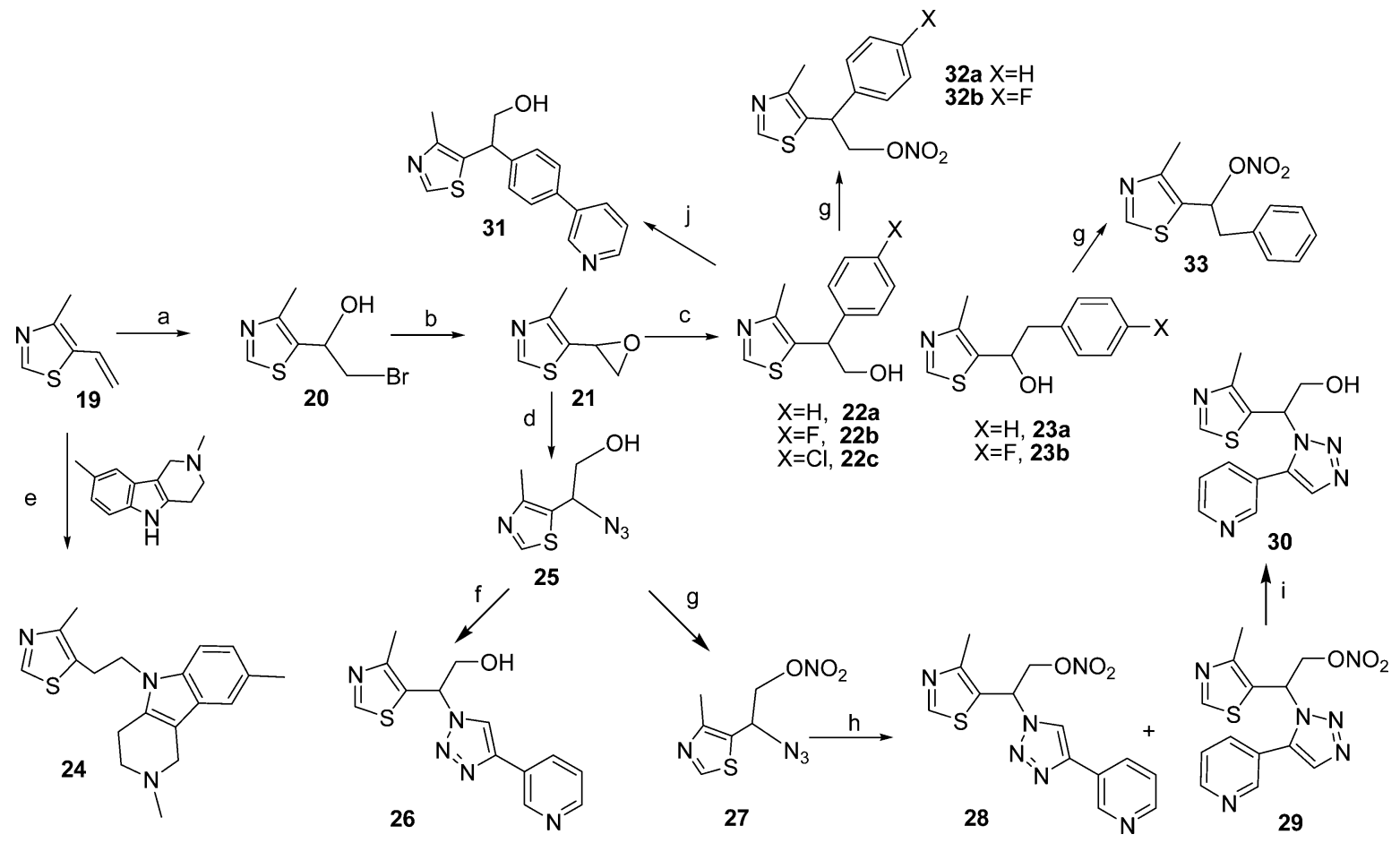

${ }^{a}$ Reagents and conditions: (a) NBS, $\mathrm{CH}_{3} \mathrm{CO}_{2} \mathrm{H}$, dioxane- $\mathrm{H}_{2} \mathrm{O}$; (b) $\mathrm{K}_{2} \mathrm{CO}_{3}, \mathrm{MeOH}$; (c) Grignard reagent, THF, $0{ }^{\circ} \mathrm{C}$ to $\mathrm{rt} ;(\mathrm{d}) \mathrm{NaN}, \mathrm{CH} \mathrm{CN}_{3}$ $\mathrm{H}_{2} \mathrm{O}(1: 1, \mathrm{v} / \mathrm{v})$, reflux; (e) $\mathrm{NaH}, \mathrm{DMSO}, 90{ }^{\circ} \mathrm{C}, 5 \mathrm{~h}$; (f) 3-ethynylpyridine, $\mathrm{CuSO}_{4} \cdot 5 \mathrm{H}_{2} \mathrm{O}$, sodium ascorbate, $t$ - $\mathrm{BuOH} / \mathrm{H}_{2} \mathrm{O}(1: 1, \mathrm{v} / \mathrm{v}) ;(\mathrm{g})$ fuming $\mathrm{HNO}_{3}, \mathrm{Ac}_{2} \mathrm{O}, \mathrm{CH}_{2} \mathrm{Cl}_{2}, 0{ }^{\circ} \mathrm{C}$; (h) 3-ethynylpyridine, toluene, reflux, $48 \mathrm{~h}$; (i) 2-mercaptoethanol, $\mathrm{Na}_{2} \mathrm{CO}_{3}, \mathrm{CH}_{3} \mathrm{CN} / \mathrm{H}_{2} \mathrm{O}$ (2:1); (j) 3pyridineboronic acid, (2-biphenyl)di-tert-butylphosphine, $\mathrm{Pd}(\mathrm{OAc})_{2}, \mathrm{KF}, \mathrm{DMF}, 120{ }^{\circ} \mathrm{C}$.

of learning and memory in vivo, and (7) demonstration of brain bioavailability and measurement of brain/plasma ratios. The drug design approach is depicted in Scheme 1.

\section{RESULTS AND DISCUSSION}

1. Synthesis of $M Z$ Derivatives. Copper(I)-catalyzed Huisgen $[3+2]$-cycloaddition between an azide and a terminal alkyne was used to afford regioselectively 1,4-disubstituted- $1 \mathrm{H}$ 1,2,3-triazoles, based upon the mild conditions, reliable high yield, and chemoselectivity of this "click" reaction. ${ }^{51-53}$ Azide 3 was synthesized in two steps and reacted with commercially available alkynes, including alkyl (e.g., 1-hexyne, ethynyltrimethylsilane, propargylbenzene) and aryl (e.g., ethynylbenzene, regioisomers of ethynylpyridine, 3-ethynylthiophene, and 5ethynyl-1-methyl-1H-imidazole), to generate a small library of 4-methyl-5-(phenyl(1H-1,2,3-triazol-1-yl)methyl)thiazole derivatives $(\mathbf{5 a}-\mathbf{i})$, and in addition, one fluorinated analogue 8 was also prepared (Scheme 2). The goal was to increase diversity of $\mathrm{MZ}$ derivatives and identify novel neuroprotective scaffolds. Accordingly 5-(2-(1H-1,2,3-triazol-1-yl)ethyl)-4methylthiazole derivatives $(11 \mathbf{a}-\mathbf{c})$ and two 5-benzyl-4methylthiazole derivatives were synthesized $(\mathbf{6 a}, \mathbf{b})$. Of all the click products, compound $\mathbf{5 d}$ was identified as an excellent neuroprotectant using in vitro bioassays (discussed below), whereas removal of the 3-pyridyl substitutent $(\mathbf{5 i})$, replacement of the pyridine ring with phenyl $(\mathbf{5 b})$ or other heterocycles $(\mathbf{5 g}$, $\mathbf{5 h})$, and changing the position of the nitrogen $(\mathbf{5 e}, \mathbf{5 f})$ led to reduced efficacy. A similar structure-activity pattern was observed for 11a-c. Thus, the 3-(1H-1,2,3-triazole-4-yl)pyridine fragment is a potential neuroprotective pharmacophore and was used to develop further MZ derivatives.
Synthesis of MZ analogues, retaining the 5-ethyl-4methylthiazole motif of both CMZ and 1, proceeded from 4methyl-5-vinylthiazole (19) to yield the alcohols 22 and 23 (Scheme 3). Epoxide intermediate $\mathbf{2 1}$ was added dropwise to Grignard reagents to give $22 \mathrm{a}-\mathrm{c}$ as major products. Although the ultimate objective was to modify $\mathrm{MZ}$ derivatives as NOchimeras, compounds such as the indole derivative $\mathbf{2 4}$ served to extend and explore the MZ structural space. Compound 24 also represents an analogue of latrepirdine, a once-promising new $\mathrm{AD}$ drug. ${ }^{54}$ Tetrahydrocarboline, the starting material for 24, was made according to a published procedure. ${ }^{55}$ To incorporate the newly discovered 3-(1H-1,2,3-triazole-4-yl)pyridine pharmacophore into NO-chimera scaffolds, azido alcohol 25 was obtained by treating epoxide 21 with sodium azide and reacting with 3-ethylnylpyridine under standard click chemistry conditions to give cycloaddition product 26. Compound 31, a close structural analogue of 26, was synthesized from 22c using Suzuki coupling to investigate the tolerance of neuroprotection to triazole ring replacement in the novel pharmacophore.

2. CMZ Pharmacology Underlying the Design and Biossay of MZ Derivatives. Many papers have discussed the biological activity of CMZ in clinical settings and in animal models. Thiazole derivatives have long been known to manifest sedative/hypnotic and anticonvulsant effects that are indicative of GABA-mimetic activity. ${ }^{15,16}$ The prototype NO-chimera 1 releases 5-(2-hydroxyethyl)-4-methylthiazole (HMZ) as primary metabolite, which was first reported in 1956 to be an anticonvulsant agent in rabbits. ${ }^{56} \mathrm{CMZ}$ has been shown extensively to be neuroprotective in animal models of transient and global ischemia. $\mathrm{CMZ}$ potentiates $\mathrm{GABA}$ and muscimol agonism at the $\mathrm{GABA}_{\mathrm{A}}$ receptor without evidence for 
modulation of levels of GABA itself and opens neuronal Cadependent chloride channels enhancing inhibitory neurotransmission. At concentrations 100 -fold those required to potentiate GABA function $(30 \mu \mathrm{M}), \mathrm{CMZ}$ is a direct $\mathrm{GABA}_{\mathrm{A}}$ receptor agonist. ${ }^{57-59} \mathrm{CMZ}$ is not a ligand for the $\mathrm{GABA}_{\mathrm{B}}$ or benzodiazepine receptors and potentiates the actions of glycine on inhibitory neurotransmission. ${ }^{6-8}$

The mechanism of action of CMZ appears not to be limited to $\mathrm{GABA}_{\mathrm{A}}$ potentiation, ${ }^{60,61}$ since $\mathrm{CMZ}$ has been claimed to be a p38-MAPK (mitogen activated protein kinase) pathway inhibitor, although the exact protein target was not defined. ${ }^{68,69}$ In Alzheimer's therapy, inhibition of p38-MAPK is seen as a target, since, for example, A $\beta$-mediated inhibition of LTP involves stimulation of the p38 MAPK cascade. ${ }^{62,63}$ Compound 4 (Scheme 2) is the lone analogue of CMZ for which mechanistic data have been reported. In the gerbil model of global ischemia, protection by $R-4$ and $S-4$ was equivalent to $\mathrm{CMZ}^{6}$ however, $R-4$ was reported to be devoid of anticonvulsant activity, suggested to be compatible with a mechanism involving GABA reuptake inhibition.?

CMZ has a short half-life and is extensively metabolized. Oxidative metabolism at carbon $\alpha$ to the thiazole ring leads to $\alpha$-hydroxylation and formation of metabolites from further oxidation, including an $\alpha$-chloro ketone and aldehyde. ${ }^{64,65}$ The replacement of the secondary $\alpha$-carbon by addition of a group $\mathrm{X}$ (Scheme 1) was justified to prevent metabolic oxidation to potentially electrophilic metabolites. The primary $\alpha$-hydroxyl metabolite of CMZ was also shown to have sedative activity, providing further reason to limit metabolism at this position. The rationale for exploration of the structural space represented by $\mathrm{Z}$ (Scheme 1) using aromatic and heterocyclic groups was based upon the reported biological data on MZ derivative 4 that clearly show central biological actions including neuroprotection. In the absence of an identified CMZ binding site associated with a $\mathrm{GABA}_{\mathrm{A}}$ subunit, iterative extension of the structural space was carried out by varying the structure and isomerism, represented by $n, \mathrm{X}$, and $\mathrm{Z}$ in Scheme 1 .

The selection of a bioassay for iterative design and synthesis of MZ derivatives was not immediately apparent. Despite the wealth of reports on CMZ activity in vivo, relatively few publications have described in vitro assays that could be adapted for screening of novel $\mathrm{MZ}$ analogues and derivatives for use as neuroprotectants. In SK-N-MC neuroblastoma cells, $\mathrm{CMZ}$ was reported to inhibit the glutamate-induced activation of AP-1 mediated by NMDA receptor activation. ${ }^{66,67}$ Immortalized cell cultures (e.g., SK-N-MC and the SH-SY5Y human neuroblastoma cell lines) would provide a facile system for cell-based drug screening; however, in SH-SY5Y cell cultures subject to excitotoxic insults including glutamate, NMDA, and oxygen-glucose deprivation (OGD), CMZ did not produce robust and reproducible neuroprotection (data not shown). Therefore, rat primary cortical neurons were studied as a more complete neuronal model. Excitotoxic cell death from treatment with NMDA $(100 \mu \mathrm{M})$ was inhibited reproducibly by $\mathrm{CMZ}$ treatment and by a number of $\mathrm{MZ}$ derivatives and analogues (Supporting Information, Table S1).

NMDA excitotoxicity represents only one aspect of neurotoxicity, whereas OGD provides a much more complete model simulating ischemia followed by reperfusion inducing ATP depletion, glutamate release, NMDA receptor overstimulation, mitochondrial dysfunction, ROS generation, apoptosis, and proinflammatory cytokine release. Given the evidence that multiple pathways underlie the anti-inflammatory and neuro- protective activity of CMZ, OGD in primary neurons was seen as the preferred model to screen and to correlate structure of $\mathrm{MZ}$ analogues with activity.

The simple 5-ethyl-4-methylthiazole derivatives (22, 23) studied in primary neuron OGD retained neuroprotective efficacy comparable to that of CMZ (Table 1). In contrast,

Table 1. Relative Percentage Neuroprotection of Primary Neuronal Cultures in Response to OGD after Treatment with MZ Derivatives ${ }^{a}$

\begin{tabular}{|c|c|c|c|}
\hline & $\begin{array}{l}\text { malized to } \mathrm{CM}^{-} \\
\mathrm{OGD}^{b}\end{array}$ & & $\begin{array}{l}\text { alized to } \mathrm{CMZ} \text { after } \\
\mathrm{OGD}^{b}\end{array}$ \\
\hline 5-ethy & lthiazoles & $\begin{array}{r}\text { 4-met } \\
\text { zol-1 }\end{array}$ & $\begin{array}{l}\text { enyl-( } 1 \mathrm{H}-1,2,3 \text {-tria- } \\
\text { l) thiazoles }\end{array}$ \\
\hline HMZ & $14.11 \pm 8.5$ & $5 \mathbf{a}$ & $26.8 \pm 5.2$ \\
\hline CMZ & $100^{c}$ & $5 b$ & $57.6 \pm 6.7$ \\
\hline 10 & ns & $5 c$ & $88.3 \pm 6.9$ \\
\hline $22 a$ & $99.6 \pm 1.4$ & $5 \mathrm{~d}$ & $108 \pm 3.6$ \\
\hline $22 b$ & $98.9 \pm 3.0$ & $5 e$ & $50.9 \pm 6.7$ \\
\hline $23 a$ & $102 \pm 1.5$ & $5 \mathrm{f}$ & $90.2 \pm 2.2$ \\
\hline $23 b$ & $101 \pm 3.9$ & $5 \mathrm{~g}$ & $62.0 \pm 3.6$ \\
\hline 24 & $15.4 \pm 5.9$ & $5 \mathrm{~h}$ & $93.9 \pm 1.2$ \\
\hline 25 & ns & $5 \mathrm{i}$ & $58.1 \pm 4.2$ \\
\hline 31 & $25.0 \pm 7.3$ & 8 & $87.2 \pm 3.5$ \\
\hline & & 16 & $104 \pm 1.7$ \\
\hline $\begin{array}{l}\text { (4-me } \\
\text { meth }\end{array}$ & 1-5-yl)(phenyl) & $\begin{array}{l}5-(2-(1) \\
\text { meth }\end{array}$ & $\begin{array}{l}\text {-triazol-1-yl)ethyl)-4- } \\
\text { es }\end{array}$ \\
\hline 2 & $94.0 \pm 2.9$ & $11 \mathrm{a}$ & $51.5 \pm 11.8$ \\
\hline $6 \mathbf{a}$ & $36.8 \pm 6.4$ & $11 \mathrm{~b}$ & $53.9 \pm 6.8$ \\
\hline $6 b$ & $25.0 \pm 4.6$ & $11 \mathrm{c}$ & $99.6 \pm 2.5$ \\
\hline 38 & $110.2 \pm 12.2$ & & \\
\hline 41 & $114.1 \pm 4.6$ & & \\
\hline $\begin{array}{r}2-(4-n \\
\text { triazo }\end{array}$ & $\begin{array}{l}\text { zol-5-yl)-1H-1,2 } \\
\text { nols }\end{array}$ & & \\
\hline 26 & $107.3 \pm 2.7$ & & \\
\hline 30 & $92.9 \pm 7.3$ & & \\
\hline $\begin{array}{l}a_{\%}=( \\
\text { present } \\
24 \mathrm{~h} \mathrm{n} \\
24{ }^{c} \text { Comp } \\
\text { demon } \\
\text { caused }\end{array}$ & $\begin{array}{l}\mathrm{MSO}) /(\mathrm{CM} \\
\text { mean } \pm \text { SEN } \\
\mathrm{d} \text { to vehicle }( \\
\text { before norn } \\
\text { mean increa } \\
\text { treatment. }\end{array}$ & $\begin{array}{l}\text { SO). } \\
\text { f). }{ }^{b} \mathrm{Re}_{\epsilon} \\
\text { ival) } \\
\text { n, wi } \\
\text { ll surv }\end{array}$ & $\begin{array}{l}\text { studied. Values are } \\
\text { from MTT assay at } \\
\text { Z ( } 100 \% \text { survival). } \\
\text { icle treated cells } \\
\text { approximately } 30 \%\end{array}$ \\
\hline
\end{tabular}

substitution of the phenyl ring in (4-methylthiazol-5-yl)(phenyl)methanol derivatives ( $\mathbf{2}$ versus $\mathbf{6 a}$ and $\mathbf{6 b}$ in Table 1) significantly reduced efficacy. Further, O-alkylation of 2 led to improved neuroprotection (2 versus 38 and 41 in Scheme 4). Compound 26 (Scheme 3) incorporated a 3-(1H-1,2,3triazole-4-yl)pyridine pharmacophore within the MZ scaffold. Both 26 and its regioisomer 30 were protective against OGD, whereas replacement of the triazole substitutent in 26 (26 vs 31 ) or substitution of 3-pyridyl in 5d with 2-pyridyl (5e) led to significant loss of efficacy. The results indicate that both triazole and 3-pyridyl moieties are critical structural elements to the neuroprotective 3-(1H-1,2,3-triazole-4-yl)pyridine fragment.

Mindful of the reports of GABAergic and GABAindependent mechanisms of action for CMZ, the mechanism of neuroprotection of four $\mathrm{MZ}$ derivatives was probed using the $\mathrm{GABA}_{\mathrm{A}}$ receptor channel blocker picrotoxin $(100 \mu \mathrm{M})$ that has been used extensively for selective antagonism of $\mathrm{GABA}_{\mathrm{A}}$ mediated signaling. ${ }^{68-71}$ Lower concentrations of picrotoxin deliver only partial blockade, ${ }^{72,73}$ and some studies employ higher concentrations. ${ }^{74,75}$ Muscimol, a potent, selective 
Scheme $4^{a}$

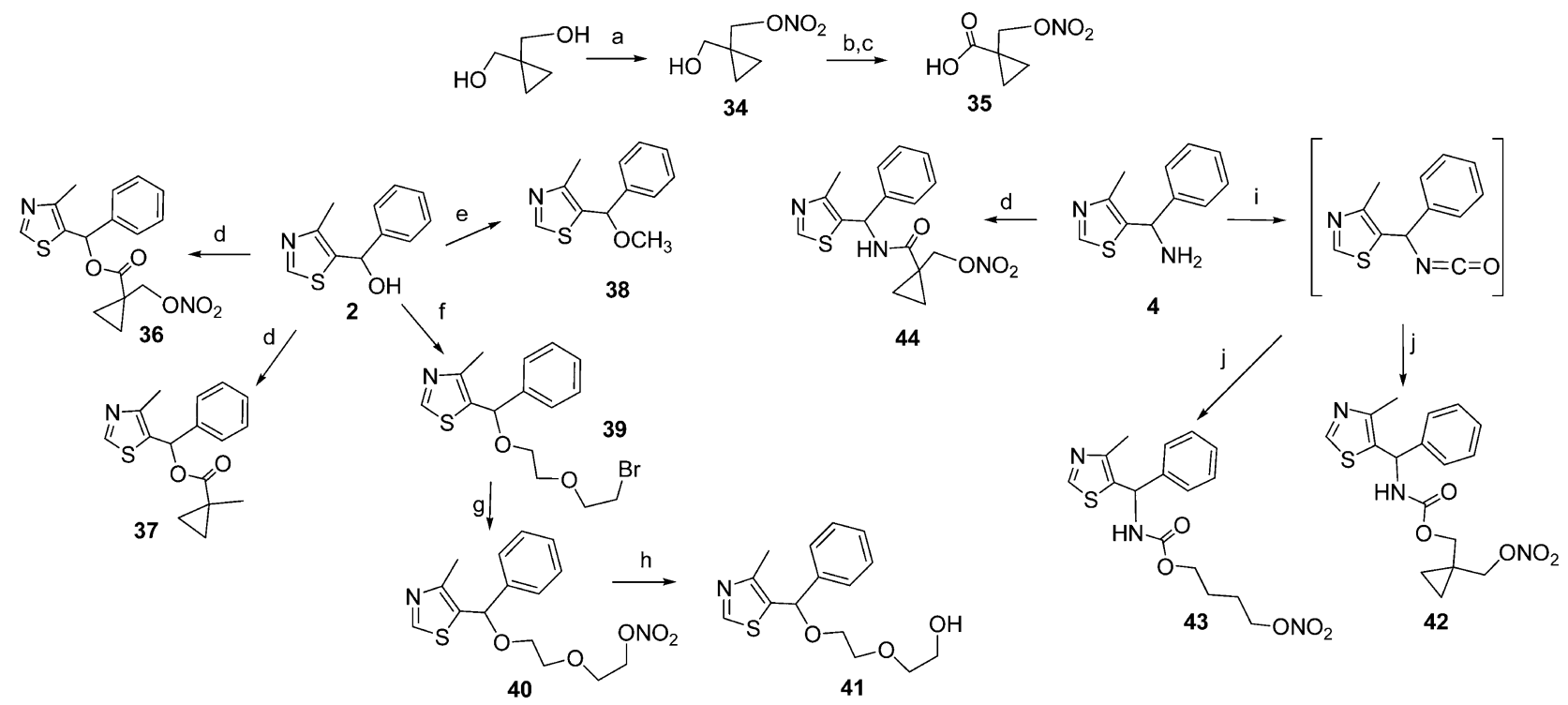

${ }^{a}$ Reagents and conditions: (a) fuming $\mathrm{HNO}_{3}, \mathrm{Ac}_{2} \mathrm{O}, \mathrm{CH}_{2} \mathrm{Cl}_{2}, 0^{\circ} \mathrm{C}$; (b) TEMPO, PhI(OAc) $)_{2} \mathrm{DCM}$; (c) $\mathrm{NaClO}_{2}, \mathrm{NaH}_{2} \mathrm{PO}_{4}, 2$-methyl-2-butene, $t$ $\mathrm{BuOH}_{\text {; }}$ (d) 35 (for 36, 44) or 1-methylcyclopropane-1-carboxylic acid (for 37), EDCI, DIPEA, HOBT, DCM; (e) NaH, CH $\mathrm{H}_{3}$, DMF; (f) bis (2bromomethyl) ether, $\mathrm{NaH}, \mathrm{DMF}$; $(\mathrm{g}) \mathrm{AgNO}_{3}, \mathrm{CH}_{3} \mathrm{CN}$, reflux; (h) $\mathrm{LiAlH}_{4}$, THF, reflux; (i) triphosgene, AcOEt, reflux; (j) 34 (for 42) or 4nitrooxybutan-1-ol (for 43), $\mathrm{NEt}_{3}$, THF.

$\mathrm{GABA}_{\mathrm{A}}$ receptor agonist, was studied for comparison. Instead of OGD, the simpler excitotoxic insult delivered by glutamate $(100 \mu \mathrm{M})$ was used to induce neuronal loss, measured at $24 \mathrm{~h}$ (Figure 1). As anticipated, muscimol produced effective neuroprotection against glutamate toxicity, which was lost and reversed on blockade of the $\mathrm{GABA}_{\mathrm{A}}$ chloride channel. Neuroprotection produced by $22 \mathrm{a}$ mirrored that by muscimol, indicating a GABAergic neuroprotective mechanism. In contrast, neuroprotection by $11 \mathrm{c}$ was significantly attenuated by $\mathrm{GABA}_{\mathrm{A}}$ receptor blockade but was not ablated or reversed, indicating a neuroprotective mechanism only partially dependent on the $\mathrm{GABA}_{\mathrm{A}}$ receptor. $\mathrm{MZ}$ derivatives 26 and 41 demonstrated intermediate neuroprotective mechanisms. On the basis of these collected data, a neuroprotective pharmacophore was speculated (Figure 1). Full elucidation of the individual GABA-dependent and GABA-independent pharmacophores requires extended structure-activity studies; however, the objective was achieved: to develop novel $\mathrm{MZ}$ derivatives to be functionalized as NO-chimeras.

3. Synthesis of NO-Chimeras. MZ derivatives (e.g., compounds 5d, 22, 23, and 26, Table 1) were selected for further study based upon efficacy for neuroprotection against OGD-induced cell death and the feasibility of structural modification to give nitrate $\mathrm{NO}$-chimeras. Compound $\mathbf{5 d}$ is as an excellent neuroprotectant against OGD and NMDA induced cytotoxicity. Compound $\mathbf{1 6}$ (Scheme 2) is an analogue of $\mathbf{5 d}$ providing a hydroxyl group on the pyridine ring and allowing modification as an NO-chimera. A TMS protected alkyne was introduced into the pyridine derivative 13 via a Sonogoshira reaction, yielding 14, which underwent direct reaction with azide 3 in a basic methanolic solution, as adapted from the literature. ${ }^{76}$ The MOM protecting group of 15 was removed, and NO-chimera 18 was prepared by coupling of 16 with 4-nitrooxybutan-1-ol under Mitsunobu conditions. Similarly, 17 , the denitration product of 18 , was made by using 4 acetyloxybutan-1-ol as reactant followed by deacetylation. Both 16 and 17 are potential metabolites of the NO-chimera 18; notably 16 retained neuroprotective efficacy comparable to that of CMZ (Table 1).

Two general strategies were used for synthesis of nitrate NOchimeras. The first used simple electrophilic or nucleophilic nitration procedures to generate nitrate esters from alcohol or halide intermediates, respectively. For instance, NO-chimeras 32a,b and 33 were prepared from hydroxyl MZ precursors 22a,b and 23a by the treatment of a mixture of acetic anhydride and fuming nitric acid (Scheme 3). However, this method failed to directly convert 26 to NO-chimera 28; therefore, nitrate 27 was prepared from intermediate $\mathbf{2 5}$ and then reacted with 3ethynylpyridine in the presence of ascorbate and $\mathrm{CuSO}_{4}$. The expected instability of the nitrate moiety under these reductive conditions led to a low yield of $\mathbf{2 6}$ as major and $\mathbf{2 8}$ as minor product. However, a mixture of $\mathbf{2 5}$ and alkyne refluxed in toluene successfully gave both regioisomers 28 and 29 by thermal cycloaddition. The nitrate group of $\mathbf{2 9}$ was removed using thiol under basic conditions to yield MZ derivative 30 (Scheme 3).

The second strategy of synthesizing NO-chimeras was to incorporate a labile linker group that would distance the nitrate from the MZ core in an approach more akin to that used in hybrid nitrates such as NO-NSAIDs. Esters of cyclopropane carboxylic acid have been reported to possess substantially increased stability toward both acid- and base-catalyzed hydrolysis. ${ }^{77}$ Inspired by this observation, 1-nitrooxymethylcyclopropanecarboxylic acid (35, Scheme 4) was prepared by mononitration and sequential oxidation. Acid 35 was coupled with 2 to yield NO-chimera 36 which was expected to have enhanced stability to esterase hydrolysis and therefore theoretically predicted to have enhanced brain bioavailability. An alternative use of this strategy led to design and synthesis of the carbamate prodrug 42, using the isocyanate precursor obtained from 4 reacting with mononitrate 34 , again predicted to have further enhanced stability. A similar procedure was used for coupling of 4-nitrooxybutan-1-ol to yield the carbamate 43 . Preparation of the amide-linked prodrug 44 and compound 37 


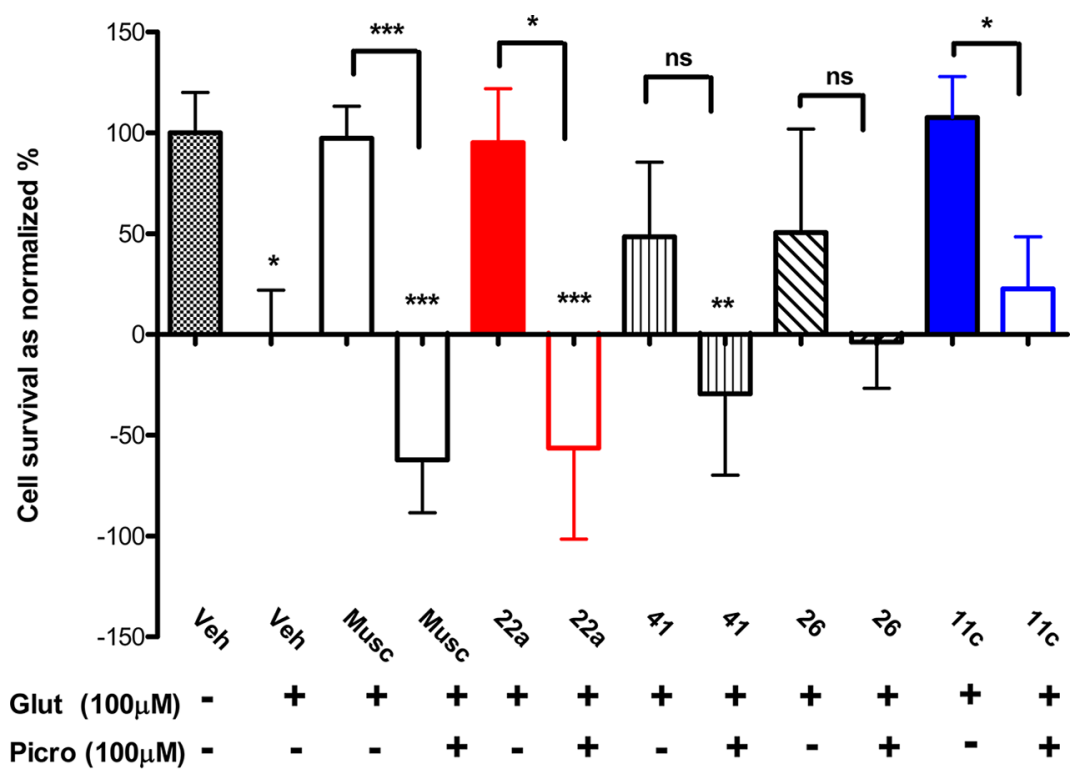

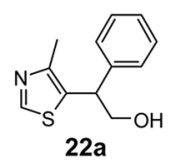

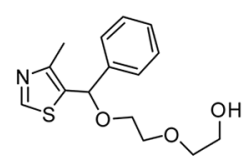

41<smiles>Cc1ncsc1CCn1cc(-c2cccnc2)nn1</smiles>

$11 \mathrm{c}$

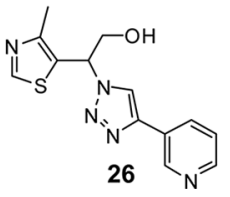

derivatization limited or absent -..

i derivatization

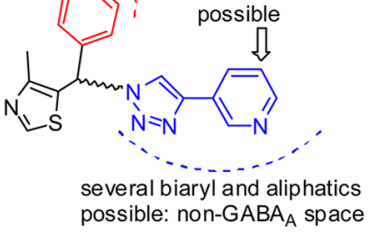

Figure 1. Inhibition by picrotoxin of neuroprotection elicited by MZ derivatives in primary neuronal cultures subject to excitotoxic insult. Primary cortical cultures (10-11 DIV) were subjected to $24 \mathrm{~h}$ of glutamate (Glut, $100 \mu \mathrm{M}$ ) toxicity with co-treatment of muscimol (Musc) or MZ derivatives $(50 \mu \mathrm{M})$. Picrotoxin (Picro, $100 \mu \mathrm{M})$ was added, where indicated, $1 \mathrm{~h}$ before glutamate treatment to provide blockade of GABA $\mathrm{A}_{\mathrm{A}}$ signaling. Survival was measured with the MTT assay and normalized to vehicle treated controls. Data show the mean and SEM from at least six individual experiments analyzed by ANOVA with post hoc Dunnett's MCT compared to nonglutamate treated vehicle control or compared to the efficacy of picrotoxin in blocking each drug treatment effect with a two-tailed $t$ test: $*, p<0.05 ; * *, p<0.01 ; * * *, p<0.001$; ns, not significant.
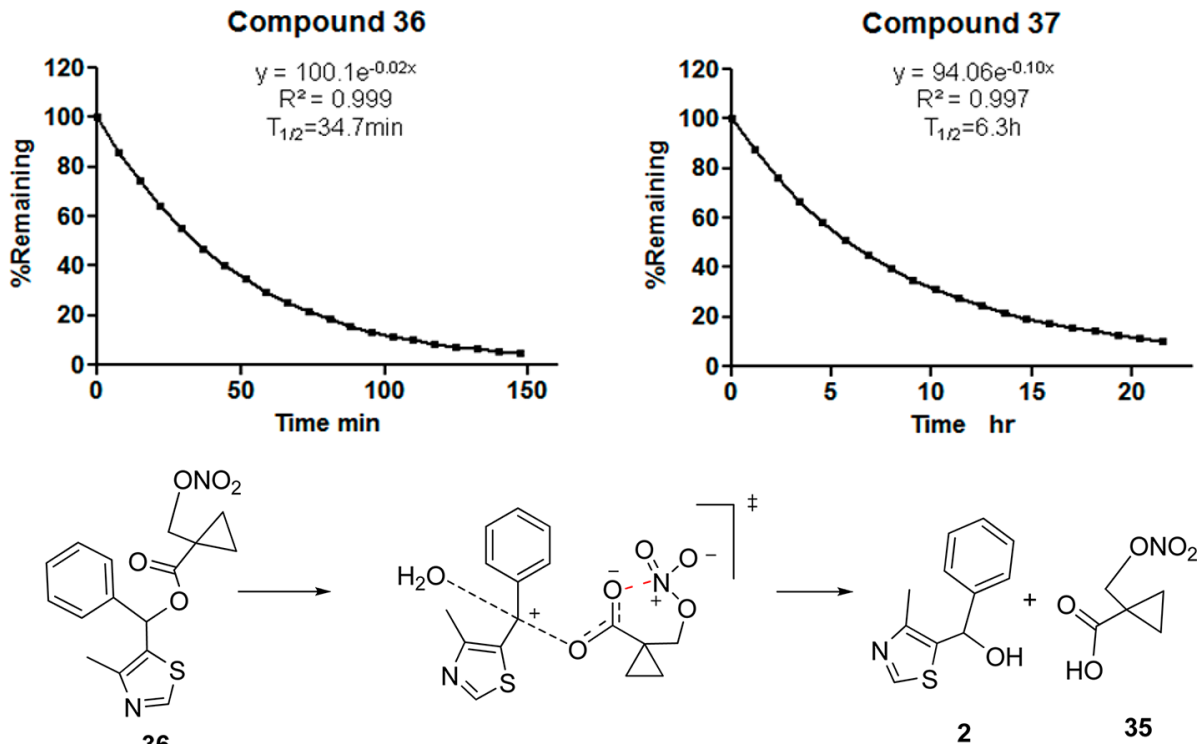

36

Figure 2. Representative kinetic traces for hydrolysis of 36 and 37 (10 $\mu \mathrm{M})$ in phosphate buffer (100 mM, pH 7.4$)$. Incubations were conducted at room temperature and monitored by HPLC with UV detection at $254 \mathrm{~nm}$ and fit to a pseudo-first-order rate equation. A putative mechanism is shown for rate acceleration by anchimeric stabilization of the anionic transition state by the nitrate group acting as intramolecular Lewis acid. 
allowed comparison with the ester-linked prodrug 36. Aliphatic nitrate 40 was synthesized from 2 by O-alkylation with dibromide and subsequent nucleophilic substitution using $\mathrm{AgNO}_{3}$. The ethylene glycol linker was incorporated to increase aqueous solubility.

4. Stability of NO-Chimeras. It was anticipated that future animal studies would require simulation of an extended release formulation, potentially by use of drug in buffered drinking water; therefore, the stability of nitrates was tested in phosphate buffer (100 mM, pH 7.4) using HPLC-UV or LC-MS monitoring. Since the nitrate group itself is stable in acid and mild alkaline solution, the observed stability over 5 days at room temperature of $\mathbf{2 8}, \mathbf{2 9}, \mathbf{3 2 a}, \mathbf{b}, \mathbf{3 3}$, and $\mathbf{4 0}$ was expected; the carbamate 43 and amide 44 were also stable. However, to our surprise, hydrolysis of $\mathbf{3 6}$ was rapid, rather than being retarded by the hindered $\alpha$-cyclopropane group, with a half-life of only about $30 \mathrm{~min}$ (Figure 2). The lability of the nitrooxymethylcyclopropanecarboxylate was unexpected, and therefore, comparison was made with the stability of $\mathbf{3 7}$ as an analogue lacking only the nitrate group. The observed half-life of about $380 \mathrm{~min}$ for ester hydrolysis confirms that the nitrate group contributes to the instability of 36 . We have previously reported the phenomenon of accelerated hydrolysis caused by an adjacent nitrate group ascribed to intramolecular Lewis acid catalysis $^{78}$ and propose a similar mechanism for 36 enhanced by a Thorpe-Ingold effect in which the developing negative charge is stabilized by the nitrate moiety through a cyclic transition state (Figure 2). Although more stable than 36, carbamate $\mathbf{4 2}$ also decomposed in phosphate buffer with a halflife of approximately $3000 \mathrm{~min}$ to yield at least four UVdetectable products that from LC-MS analysis included two denitrated products $(m / z=333$ ) (Supporting Information, Figure S1).

5. Restoration of Synaptic Function by NO-Chimeras. An early event in $\mathrm{AD}$ is synaptic failure leading to deficits in learning and memory. ${ }^{35}$ The importance of synaptic alterations in $\mathrm{AD}$ has also been confirmed by studies in transgenic mouse models of $\mathrm{AD}^{79}$ as well as on LTP, a widely studied cellular model of learning and memory. ${ }^{80}$ Previous work has reported that synaptic transmission and cognition are altered in double transgenic APP/PS1 mice expressing both the human APP mutation (K670M:N671L) and the human PS1 mutation (M146L). ${ }^{81,82}$ In hippocampal slices obtained from APP/PS1 and WT littermates between 4 and 5 months of age, reproducible LTP responses in the CA1 are observed, with a reduction of LTP in APP/PS1 hippocampal slices, as measured by field excitatory postsynaptic potential (fEPSP). A $\beta$-induced inhibition of LTP has been observed to be reversed by NOdonors via a mechanism shown to be mediated by the NO/ cGMP signaling pathway. ${ }^{47}$ Basal synaptic transmission was determined by measuring the slope of fEPSP at increasing stimulus intensities in slices from 4 to 5 month old APP/PS1 mice for NO-chimeras 32a and $42(100 \mu \mathrm{M})$ perfused for 5 min before inducing LTP through a $\theta$-burst tetanic stimulation of the Schaeffer collateral pathway (Figure 3). ${ }^{81}$ Potentiation was observed for 32a, although data for $\mathbf{4 2}$ did not reach significance $(P<0.1)$. The requirement for reductive bioactivation of nitrates to $\mathrm{NO}$ and the instability of $\mathbf{4 2}$ discussed above are likely causes of the observed differences. The potentiation of the actions of the inhibitory neurotransmitter GABA is not expected to enhance LTP, and accordingly, CMZ did not restore LTP (data not shown).
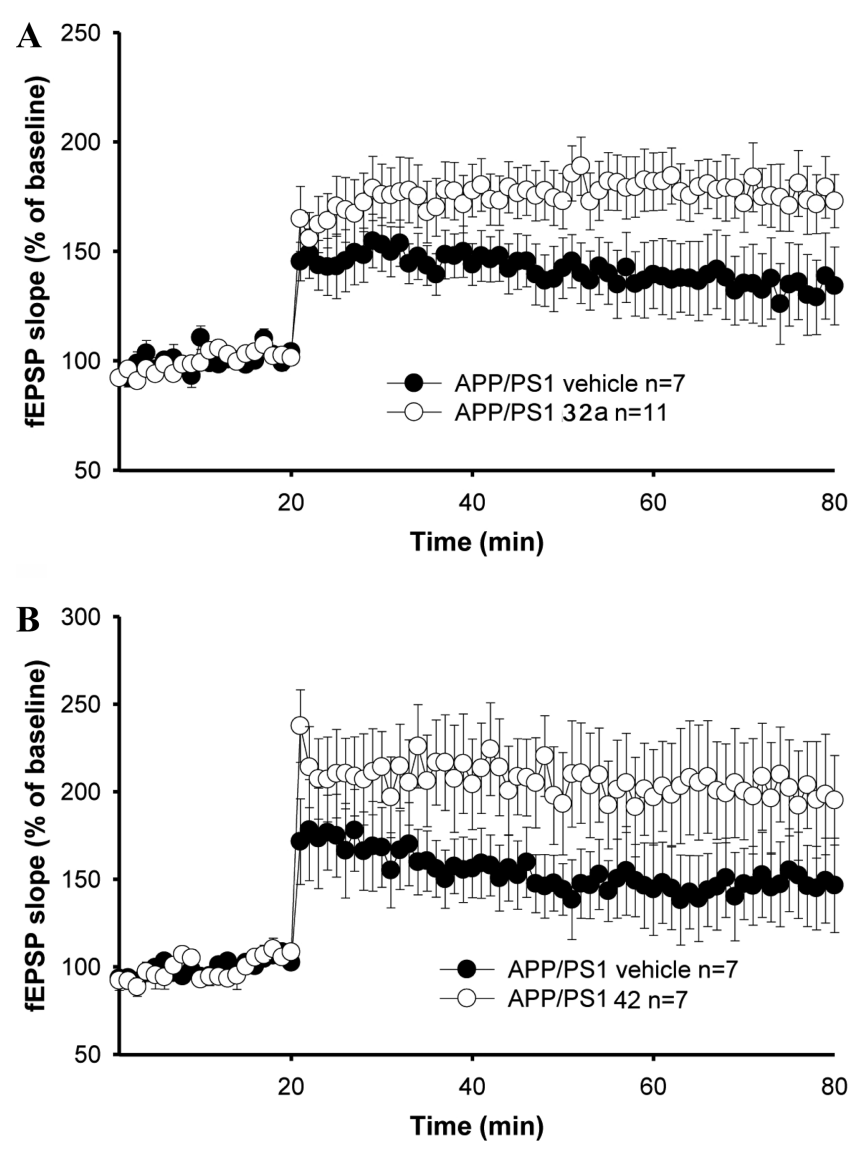

Figure 3. Restoration of CA1-LTP impairment in 3-month-old APP/ PS1 mouse hippocampal slices. (A) NO-chimera 32a rescued the LTP impairment in APP/PS1 mice $\left(F_{(1,16)}=4.129, p=0.05\right.$, compared with vehicle; 50-80 min analysis); (B) NO-chimera 42 showed a tendency toward reversal of LTP impairment without reaching significance $\left(\mathrm{F}_{(1,12)}=2.537, p=0.13\right.$, compared with vehicle $)$.

6. Restoration of Cognition by NO-Chimeras. The stepthrough passive avoidance (STPA) task was used to measure the reversal of a stimulus-response memory deficit induced by the amnesic agent scopolamine that blocks muscarinic acetylcholine receptor activation. Since muscarinic acetylcholine receptor dysfunction is relevant to $\mathrm{AD}$, scopolamineinduced amnesia remains a useful model for screening of drugs for procognitive actions. ${ }^{83}$ The STPA task tests learned aversion memory, since mice have a natural preference for dark areas over brightly lit and open areas. Following a period of habituation, the animal is placed in the light compartment of the apparatus and inevitably crosses to the dark compartment of the apparatus, at which time an electric shock is delivered. The animals rapidly learn to avoid moving into the dark compartment during the training phase, despite the administration of the amnesic agent. Retention of this newly learned behavior can be tested on subsequent days to assess the strength of the aversive memory by measuring the latency to enter the dark area. In both training and testing phases, the task is halted after $300 \mathrm{~s}$ if the animal does not enter the dark side.

STPA has a significant advantage for drug screening because the potential locomotor effects of drugs are very unlikely to confound the observations. First, all animals must show a uniform learning response to training regardless of drug treatment, which initially entails movement between the compartments until the task is learned. Second, animals are 
tested 24 and/or $48 \mathrm{~h}$ after a single drug treatment, and since most of the drugs, including all NO-chimeras that we have studied to date, have cleared the system long before memory is tested, the STPA task is primarily a measure of memory consolidation.

Scopolamine was administered $30 \mathrm{~min}$ and drugs $20 \mathrm{~min}$ before training (both ip). Drugs were administered at concentrations equimolar to $1(1 \mathrm{mg} / \mathrm{kg}$, i.e., $4.45 \mu \mathrm{mol} / \mathrm{kg})$ to provide comparison to previous work. ${ }^{84}$ Administration of scopolamine and vehicle resulted in a latency of less than $100 \mathrm{~s}$ for mice to enter the dark side of the apparatus when tested 24 $\mathrm{h}$ later, demonstrating an inability to consolidate memory. In contrast, treatment with scopolamine and all novel NOchimeras studied $(\mathbf{2 8}, \mathbf{2 9}, 32 \mathrm{a}, 32 \mathrm{~b}, \mathbf{4 0}, \mathbf{4 2}, 43)$ significantly restored memory at $24 \mathrm{~h}$ (Figure 4 ).

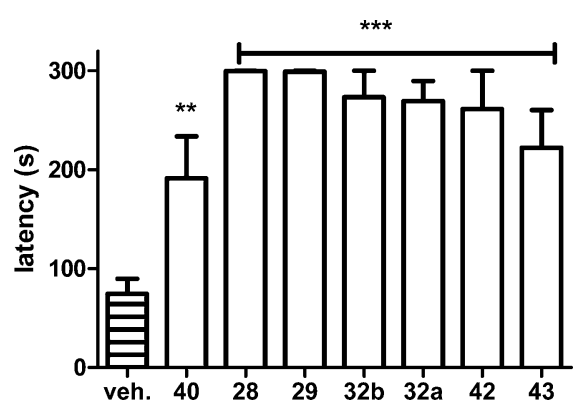

Figure 4. Procognitive effects of NO-chimeras evaluated in the scopolamine-induced memory deficit model using the STPA task. Scopolamine was administered $30 \mathrm{~min}$ and drug was administered 20 min prior to the start of training, and memory was tested $24 \mathrm{~h}$ after training and drug treatment. NO-chimeras $28,29,32 a, 32 b, 42,43$ (***, $p<0.01$, compared with vehicle), and $40(* *, p<0.05$, compared with vehicle) significantly reversed the scopolamine induced memory deficit. Data were obtained from at least five mice per group.

7. Brain Bioavailability Assessed by LC-MS/MS. Although the procognitive effects of the NO-chimeras are indicative of brain bioavailability, LC-MS/MS measurements were used to confirm blood-brain barrier penetration. Furthermore, a second objective of these assays was to measure the concentrations of MZ metabolites in the brain after NOchimera delivery, since the neuroprotective properties of the $\mathrm{MZ}$ metabolite are an important aspect of the drug design. Figure 5 shows LC-MS/MS chromatograms for multiple reaction monitoring (MRM) after administration of two NOchimeras and their MZ metabolites, representing two subclasses of NO-chimera with different physicochemical properties. The NO-chimera 32a showed good brain bioavailability, and its 5ethyl-4-methylthiazole metabolite 22 a was also observed in the brain of mice $20 \mathrm{~min}$ after administration. In contrast, the bioavailability of $\mathrm{NO}$-chimera $\mathbf{2 8}$ was low at this time point, whereas the 2-(4-methylthiazol-5-yl)-1H-1,2,3-triazol-1-ylethanol metabolite 26 was readily detected. Calculated parameters suggest that 26 (tPSA $\left.=73 \AA^{2} ; C \log \mathrm{P}<0\right)$ should not penetrate the blood-brain barrier, whereas 22a (tPSA = $33 \AA^{2}$; $\mathrm{C} \log \mathrm{P}=1.56)$ has more favorable properties; however, both $\mathrm{MZ}$ derivatives were observed in mouse brains after direct ip administration or after administration of the NO-chimera prodrug. The preliminary replicate analyses after administration of 26 and 28 suggest that the nitrate chimera prodrug elevates brain levels of 26, relative to direct administration of $\mathbf{2 6}$ itself (Table 2). These data, obtained after ip administration, are predictive of oral bioavailability by comparison with data for $1^{37}$

\section{CONCLUSIONS}

Synaptic failure is an early event in both $\mathrm{AD}$ and mild cognitive impairment (MCI), which causes impaired cognition and memory. ${ }^{1}$ Disease progression involves neurodegeneration of cortical and hippocampal neurons and loss of hippocampal volume. A drug that targets synaptic failure in addition to providing neuroprotection is a rational approach to $\mathrm{AD}$ therapy. Abnormally assembled $\mathrm{A} \beta$ and tau proteins are associated with both synaptic and neuronal dysfunction and loss. ${ }^{3} \mathrm{~A} \beta$ has been shown to down-regulate signaling via the $\mathrm{NO} / \mathrm{cGMP} / \mathrm{CREB}$ pathway; therefore, enhancement of NO/ cGMP signaling and activation of CREB may provide a novel approach for the treatment of $\mathrm{AD} .^{39-42,47,85}$ Gene products associated with CREB activation may provide neuroprotection; however, prevention of neuronal loss can also be achieved by selective pharmacological modulation of $\mathrm{GABA}_{\mathrm{A}}$ receptors, a mechanism that has been shown to provide neuroprotection against $\mathrm{A} \beta$ mediated toxicity. ${ }^{86-89}$

Herein, we have elaborated on the concept of an NOchimera, incorporating GABA-mimetic and NO-mimetic mechanisms, by developing and derivatizing novel $\mathrm{MZ}$ scaffolds. These chimeric agents represent a novel drug class coined nomethiazoles. The milestones for this study were (1) development of the $\mathrm{MZ}$ pharmacophore through synthesis of novel derivatives, (2) assay of neuroprotection in primary neurons, (3) synthesis of nomethiazoles by derivatization of novel, neuroprotective MZ scaffolds, possessing (4) satisfactory stability. Proof-of-concept for nomethiazoles was achieved by demonstration of (5) synaptic rescue using LTP measurements ex vivo, (6) restoration of learning and memory in vivo, and (7) brain bioavailability of both NO-chimeras and their $\mathrm{MZ}$ metabolites. It was confirmed that $\mathbf{1}$ is a prototype of a novel drug class that possesses a combination of GABA-mimetic and NO-mimetic activities, thus providing both neuroprotection and neurorestoration. Since neurodegenerative diseases such as $\mathrm{AD}$ are multifactorial, the development of drugs designed to target more than one mechanism of action is likely to be a promising therapeutic approach.

\section{EXPERIMENTAL SECTION}

Synthesis. ${ }^{1} \mathrm{H}$ and ${ }^{13} \mathrm{C}$ NMR spectra were obtained with Bruker Ultrashield $400 \mathrm{MHz}$ and Advance $300 \mathrm{MHz}$ spectrometers. Chemical shifts are reported as $\delta$ values in parts per million (ppm) relative to tetramethylsilane (TMS) for all recorded NMR spectra. All reagents and solvents were obtained commercially from Acros, Aldrich, and Fluka and were used without purification. Low-resolution mass spectrometry (LRMS) was conducted on an Agilent 6300 ion-trap LC-MS instrument. High resolution mass spectral data were collected using a Shimadzu QTOF 6500 instrument. All compounds submitted for biological testing were found to be $>95 \%$ pure by analytical HPLC. Purity and/or low resolution mass spectral (ESI or APCI) analysis was measured using an Agilent Zorbax Bonus C18, $3.5 \mu \mathrm{m}, 150 \mathrm{~mm} \times 3.0$ $\mathrm{mm}$ column on either a Shimadzu UFLC or Agilent 1100 series HPLC instrument in tandem with an Agilent 6310 ion trap LC-MS instrument. HPLC parameters were the following: $0.1 \% \mathrm{FA}$ in $10 \%$ $\mathrm{CH}_{3} \mathrm{OH}$ (solvent A); $0.1 \% \mathrm{FA}$ in $\mathrm{CH}_{3} \mathrm{CN}$ (solvent B); flow rate 0.5 $\mathrm{mL} / \mathrm{min}$; gradient, $t=0 \mathrm{~min}, 10 \% \mathrm{~A} ; t=1 \mathrm{~min}, 10 \% \mathrm{~A} ; t=18 \mathrm{~min}$, $80 \% \mathrm{~A} ; t=20 \mathrm{~min}, 80 \% \mathrm{~A} ; t=21 \mathrm{~min}, 95 \% \mathrm{~A}$.

1-(4-Methyl-5-thiazolyl)-1-phenylmethanol (2). 4-Methyl-5thiazolecarboxaldehyde $(1.0 \mathrm{~g}, 7.8 \mathrm{mmol})$ was dissolved in THF (40 $\mathrm{mL}$ ) and cooled in an ice bath, and phenylmagnesium bromide (1 M in THF, $8.5 \mathrm{~mL}$ ) was added dropwise. The reaction mixture was 

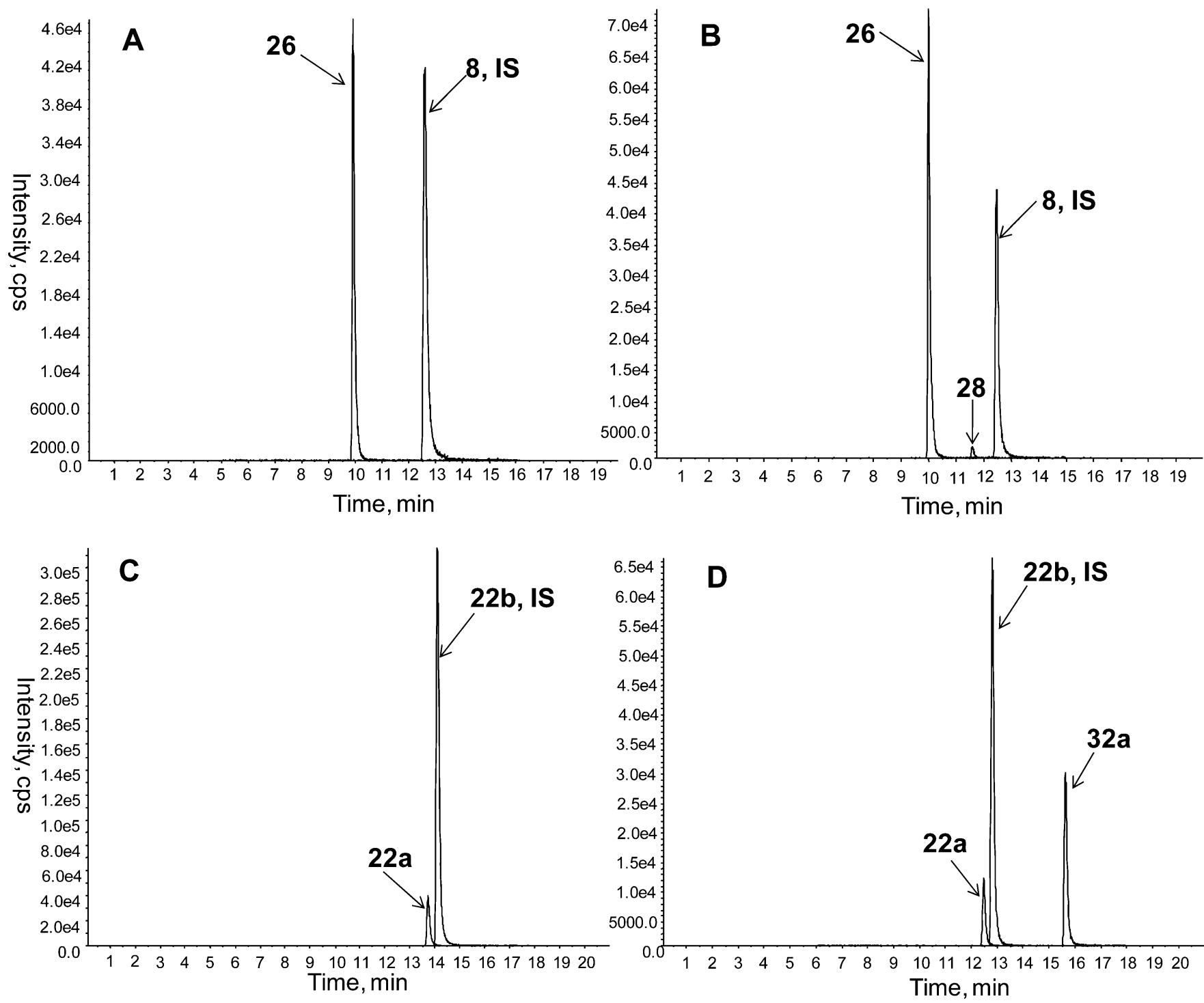

Figure 5. MRM LC-MS/MS chromatograms of extracted mouse brain samples 20 min after ip delivery of each drug at a dosage that was equimolar with $1(4.5 \mu \mathrm{mol} / \mathrm{kg})$ : (A) 26 with 8 used as internal standard; (B) 28 with 8 used as internal standard; (C) 22a with 22b used as internal standard; (D) 32a with $22 b$ used as internal standard.

Table 2. Analysis of Selected MZ Derivatives and NOChimeras in Mice Brain Tissue

\begin{tabular}{ccccc}
$\begin{array}{c}\text { injected } \\
\text { drug (ip) }\end{array}$ & analyte & $\begin{array}{c}\text { MRM } \\
\text { transition of } \\
\text { analytes }\end{array}$ & $\begin{array}{c}\text { internal standard and } \\
\text { MRM transition }\end{array}$ & $\begin{array}{c}\text { brain concn } \\
(\mathrm{ng} / \mathrm{mL})^{\boldsymbol{a}}\end{array}$ \\
\hline $\mathbf{2 8}$ & $\mathbf{2 8}$ & $333 \rightarrow 288$ & $\mathbf{8}, 352 \rightarrow 147$ & $2.1 \pm 0.6$ \\
$\mathbf{2 8}$ & $\mathbf{2 6}$ & $288 \rightarrow 147$ & $\mathbf{8}, 352 \rightarrow 147$ & $76.6 \pm 10.2$ \\
$\mathbf{2 6}$ & $\mathbf{2 6}$ & $288 \rightarrow 147$ & $\mathbf{8 , 3 5 2} \rightarrow 147$ & $56.4 \pm 5.5$ \\
32a & 32a & $265 \rightarrow 220$ & $\mathbf{2 2 b}, 238 \rightarrow 207$ & $9.5 \pm 0.6$ \\
32a & 22a & $220 \rightarrow 189$ & $\mathbf{2 2 b}, 238 \rightarrow 207$ & $9.5 \pm 1.1$ \\
22a & 22a & $220 \rightarrow 189$ & $\mathbf{2 2 b}, 238 \rightarrow 207$ & $32.9 \pm 3.7$
\end{tabular}

${ }^{a}$ Four mice were used for the injection of each drug. Values are presented as the mean $\pm \operatorname{SEM}(n=4)$.

warmed to room temperature and stirred overnight. The reaction was quenched with aqueous $\mathrm{NH}_{4} \mathrm{Cl}$, and extraction was with ethyl acetate $(2 \times 100 \mathrm{~mL})$. Organic solutions were combined and concentrated, and the crude product was purified by column chromatography (hexanes/ethyl acetate, 1:1, $1.4 \mathrm{~g}, 87 \%$ ). ${ }^{1} \mathrm{H}$ NMR (acetone- $d_{6}, 400$ $\mathrm{MHz}): \delta 8.81(\mathrm{~s}, 1 \mathrm{H}), 7.45(\mathrm{~d}, 2 \mathrm{H}, J=7.2 \mathrm{~Hz}) 7.24-7.36(\mathrm{~m}, 3 \mathrm{H})$, $6.16(\mathrm{~d}, 1 \mathrm{H}, J=3.6 \mathrm{~Hz}), 5.34(\mathrm{~d}, 1 \mathrm{H}, J=3.6 \mathrm{~Hz}), 2.38(\mathrm{~s}, 3 \mathrm{H}) .{ }^{13} \mathrm{C}$
NMR (acetone- $\left.d_{6}, 100 \mathrm{MHz}\right): \delta 151.57,148.90,145.14,137.96$ $129.09,128.20,126.92,69.66,15.54$.

5-(Azidophenylmethyl)-4-methylthiazole (3). $\mathrm{MsCl}(2.9 \mathrm{~mL})$ was added to a solution of $2(6.2 \mathrm{~g})$ and $\mathrm{NEt}_{3}(6.0 \mathrm{~mL})$ in anhydrous acetonitrile $(70 \mathrm{~mL})$. Reaction was monitored by TLC until the starting material was consumed. $\mathrm{NaN}_{3}(6.1 \mathrm{~g})$ was added, and the mixture was stirred at room temperature overnight. Most of the acetonitrile was removed under reduced pressure. The residue was diluted with ethyl acetate and washed with water. The organic phase was separated and concentrated, and the crude product was purified by column chromatography (hexane/ethyl acetate, 2:1, 75\%). ${ }^{1} \mathrm{H}$ NMR (acetone- $\left.d_{6}, 400 \mathrm{MHz}\right): \delta 8.87(\mathrm{~s}, 1 \mathrm{H}), 7.34-7.47(\mathrm{~m}, 5 \mathrm{H}), 6.41(\mathrm{~s}$, $1 \mathrm{H}), 2.45(\mathrm{~s}, 3 \mathrm{H}) .{ }^{13} \mathrm{C}$ NMR (acetone- $\left.d_{6}, 100 \mathrm{MHz}\right): \delta$ 152.86, $151.16,140.13,131.97,129.67,129.24,127.62,61.78,15.55$. HRMS calcd for $\mathrm{C}_{11} \mathrm{H}_{10} \mathrm{~N}_{4} \mathrm{~S}[\mathrm{M}+\mathrm{H}]^{+}$231.0704, found 231.0713.

$\alpha$-Phenyl-(4-methyl-5-thiazolyl)methanamine (4). $\mathrm{LiAlH}_{4}$ $(130 \mathrm{mg}, 3.5 \mathrm{mmol})$ was added to a solution of $3(320 \mathrm{mg}, 1.39$ $\mathrm{mmol})$ in anhydrous THF $(10 \mathrm{~mL})$. The mixture was refluxed for $1 \mathrm{~h}$ and quenched with $0.1 \mathrm{~N} \mathrm{NaOH}$. The residue was diluted with water and extracted using ethyl acetate $(2 \times 25 \mathrm{~mL})$. Organic solutions were combined and concentrated, and the crude product was purified by column chromatography (DCM/MeOH, 15:1, $230 \mathrm{mg}, 82 \%) .{ }^{13} \mathrm{C}$ 
NMR ( $\left.\mathrm{CD}_{3} \mathrm{CN}, 100 \mathrm{MHz}\right): \delta 151.62,148.35,145.96,139.76,129.52$, 128.23, 127.51, 53.69, 15.61. HRMS calcd for $\mathrm{C}_{11} \mathrm{H}_{12} \mathrm{~N}_{2} \mathrm{~S}[\mathrm{M}+\mathrm{H}]^{+}$ 205.0799, found 205.0807.

Compound 5. Standard Click Chemistry Procedure. Azide (1 equiv) and alkyne ( 1 equiv) were dissolved in $t-\mathrm{BuOH}$ and water (1:1). Sodium ascorbate ( 0.2 equiv) and $\mathrm{CuSO}_{4} \cdot 5 \mathrm{H}_{2} \mathrm{O}$ (0.1 equiv) were added. The reaction mixture was stirred overnight, diluted with ethyl acetate, and washed with water. The organic phase was separated and concentrated, and the crude product was purified by column chromatography (DCM/MeOH, 20:1, yield 75-90\%). For compounds $5 \mathbf{i}$ and $11 \mathrm{a}$, the solvent was changed to a mixture of $\mathrm{MeOH}$ and $\mathrm{H}_{2} \mathrm{O}(2: 1, \mathrm{v} / \mathrm{v}) . \mathrm{K}_{2} \mathrm{CO}_{3}$ ( 1 equiv) was also added in addition to other reactants.

4-Butyl-1-[(4-methyl-5-thiazolyl)phenylmethyl]-1 $\mathrm{H}$-1,2,3-triazole (5a). 1-Hexyne was reacted with 3 to give 5 a. ${ }^{1} \mathrm{H}$ NMR (acetone- $\left.d_{6}, 400 \mathrm{MHz}\right): \delta 8.92(\mathrm{~s}, 1 \mathrm{H}), 7.83(\mathrm{~s}, 1 \mathrm{H}), 7.48(\mathrm{~s}, 1 \mathrm{H})$, 7.35-7.41(m, 3H), 7.27-7.28 (m, 2H), $2.68(\mathrm{t}, 2 \mathrm{H}, J=8.0 \mathrm{~Hz}), 2.36$ $(\mathrm{s}, 3 \mathrm{H}), 1.58-1.66(\mathrm{~m}, 2 \mathrm{H}), 1.29-1.38(\mathrm{~m}, 2 \mathrm{H}), 0.88(\mathrm{t}, 3 \mathrm{H}, J=7.6$ $\mathrm{Hz}) .{ }^{13} \mathrm{C}$ NMR (acetone- $\left.d_{6}, 100 \mathrm{MHz}\right): \delta$ 153.50, 152.51, 148.66, $140.45,131.10,129.67,129.34,127.72,122.08,61.08,32.23,25.86$, 22.79, 15.40, 14.02. HRMS calcd for $\mathrm{C}_{17} \mathrm{H}_{20} \mathrm{~N}_{4} \mathrm{~S}[\mathrm{M}+\mathrm{H}]^{+} 313.1481$, found 313.1468 .

1-[(4-Methyl-5-thiazolyl)phenylmethyl]-4-phenyl-1 $H$-1,2,3triazole (5b). Ethynylbenzene was reacted with $\mathbf{3}$ to give $\mathbf{5 b} .{ }^{1} \mathrm{H}$ NMR (acetone- $\left.d_{6}, 400 \mathrm{MHz}\right): \delta 9.02(\mathrm{~s}, 1 \mathrm{H}), 8.48(\mathrm{~s}, 1 \mathrm{H}), 7.92-7.94$ (m, 2H), $7.58(\mathrm{~s}, 1 \mathrm{H}), 7.30-7.45(\mathrm{~m}, 8 \mathrm{H}), 2.41(\mathrm{~s}, 3 \mathrm{H}) .{ }^{13} \mathrm{C} \mathrm{NMR}$ (acetone- $\left.d_{6}, 100 \mathrm{MHz}\right): \delta 147.98,140.23,131.82,129.77,129.55$, $129.48,128.75,127.74,126.29,121.31,61.47,15.47$. HRMS calcd for $\mathrm{C}_{19} \mathrm{H}_{16} \mathrm{~N}_{4} \mathrm{~S}[\mathrm{M}+\mathrm{H}]^{+}$333.1174, found 333.1186.

1-[(4-Methyl-5-thiazolyl)phenylmethyl]-4-(phenylmethyl)$1 \mathrm{H}-1,2,3$-triazole (5c). Propargylbenzene was reacted with 3 to give 5c. ${ }^{1} \mathrm{H}$ NMR (DMSO- $\left.d_{6}, 400 \mathrm{MHz}\right): \delta 8.98(\mathrm{~s}, 1 \mathrm{H}), 7.97(\mathrm{~s}, 1 \mathrm{H}), 7.53$ (s, 1H), 7.17-7.41 (m, 10H), $4.01(\mathrm{~s}, 2 \mathrm{H}), 2.31(\mathrm{~s}, 3 \mathrm{H}) .{ }^{13} \mathrm{C}$ NMR $\left(\mathrm{CDCl}_{3}, 100 \mathrm{MHz}\right): \delta 153.82,150.92,146.33,139.46,139.36,129.81$, $128.99,128.57,128.52,126.81,126.29,122.78,59.37,31.19,15.05$. HRMS calcd for $\mathrm{C}_{20} \mathrm{H}_{18} \mathrm{~N}_{4} \mathrm{~S}[\mathrm{M}+\mathrm{H}]^{+} 347.1330$, found 347.1344.

3-[1-[(4-Methyl-5-thiazolyl)phenylmethyl]-1H-1,2,3-triazol4-yl]pyridine (5d). 3-Ethynylpyridine was reacted with $\mathbf{3}$ to give $\mathbf{5 d}$. ${ }^{1} \mathrm{H}$ NMR (DMSO- $d_{6}, 400 \mathrm{MHz}$ ): $\delta 9.10(\mathrm{bs}, 1 \mathrm{H}), 9.03(\mathrm{~s}, 1 \mathrm{H}), 8.83$ (s, 1H), $8.54(\mathrm{bs}, 1 \mathrm{H}), 8.25(\mathrm{~d}, 1 \mathrm{H}, J=8.0 \mathrm{~Hz}), 7.67(\mathrm{~s}, 1 \mathrm{H}), 7.29-$ $7.49(\mathrm{~m}, 6 \mathrm{H}), 2.45(\mathrm{~s}, 3 \mathrm{H}) .{ }^{13} \mathrm{C}$ NMR (DMSO- $\left.d_{6}, 100 \mathrm{MHz}\right): \delta$ $153.98,151.42,149.12,146.58,143.77,139.09,132.71,129.48,129.08$, $128.76,126.87,126.41,124.08,122.18,59.87,15.12$. HRMS calcd for $\mathrm{C}_{18} \mathrm{H}_{15} \mathrm{~N}_{5} \mathrm{~S}[\mathrm{M}+\mathrm{H}]^{+}$334.1126, found 334.1118.

2-[1-[(4-Methyl-5-thiazolyl)phenylmethyl]-1H-1,2,3-triazol4-yl]pyridine (5e). 2-Ethynylpyridine was reacted with 3 to give 5e. ${ }^{1} \mathrm{H}$ NMR (acetone- $\left.d_{6}, 400 \mathrm{MHz}\right): \delta 8.95(\mathrm{~s}, 1 \mathrm{H}), 8.55(\mathrm{~d}, 1 \mathrm{H}, J=4.0$ $\mathrm{Hz}), 8.51(\mathrm{~s}, 1 \mathrm{H}), 8.15(\mathrm{~d}, 1 \mathrm{H}, J=8.0 \mathrm{~Hz}), 7.85$ (triple doublet, $1 \mathrm{H}, J$ $=8.0,1.6 \mathrm{~Hz}), 7.64(\mathrm{~s}, 1 \mathrm{H}), 7.21-7.45(\mathrm{~m}, 6 \mathrm{H}), 2.43(\mathrm{~s}, 3 \mathrm{H}) .{ }^{13} \mathrm{C}$ NMR (acetone- $\left.d_{6}, 100 \mathrm{MHz}\right): \delta 153.73,152.61,151.51,150.42$, $148.90,140.03,137.59,130.37,129.79,129.51,127.74,123.69,123.32$, 120.34, 61.43, 15.43. HRMS calcd for $\mathrm{C}_{18} \mathrm{H}_{15} \mathrm{~N}_{5} \mathrm{~S}[\mathrm{M}+\mathrm{H}]^{+} 334.1126$, found 334.1129 .

4-[1-[(4-Methyl-5-thiazolyl)phenylmethyl]-1H-1,2,3-triazol4-yl]pyridine (5f). 4-Ethynylpyridine was reacted with 3 to give $\mathbf{5 f}$. ${ }^{1} \mathrm{H} \mathrm{NMR}\left(\mathrm{CDCl}_{3}, 400 \mathrm{MHz}\right): \delta 8.75(\mathrm{~s}, 1 \mathrm{H}), 8.61(\mathrm{~d}, 2 \mathrm{H}, J=4.8 \mathrm{~Hz})$, $8.01(\mathrm{~s}, 1 \mathrm{H}), 7.71(\mathrm{~d}, 2 \mathrm{H}, J=5.6 \mathrm{~Hz}), 7.34-7.40(\mathrm{~m}, 4 \mathrm{H}), 7.18-7.20$ $(\mathrm{m}, 2 \mathrm{H}), 2.42(\mathrm{~s}, 3 \mathrm{H}) .{ }^{13} \mathrm{C} \mathrm{NMR}\left(\mathrm{CDCl}_{3}, 100 \mathrm{MHz}\right): \delta 152.49$, $151.94,150.09$, 145.12, 137.55, 137.39, 129.02, 128.99, 128.81, 126.46, $120.65,119.73,60.96,15.18$. HRMS calcd for $\mathrm{C}_{18} \mathrm{H}_{15} \mathrm{~N}_{5} \mathrm{~S}[\mathrm{M}+\mathrm{H}]^{+}$ 334.1126, found 334.1119.

1-[(4-Methyl-5-thiazolyl)phenylmethyl]-4-(3-thienyl)-1 $\mathrm{H}$ 1,2,3-triazole $(\mathbf{5 g})$. 3-Ethynylthiophene was reacted with 3 to give 5g. ${ }^{1} \mathrm{H}$ NMR $\left(\mathrm{CDCl}_{3}, 400 \mathrm{MHz}\right): \delta 8.74(\mathrm{~s}, 1 \mathrm{H}), 7.69(\mathrm{~d}, 1 \mathrm{H}, J=2.0$ $\mathrm{Hz}), 7.60(\mathrm{~s}, 1 \mathrm{H}), 7.36-7.44(\mathrm{~m}, 5 \mathrm{H}), 7.30(\mathrm{~s}, 1 \mathrm{H}), 7.15-7.16(\mathrm{~m}$, $2 \mathrm{H}), 2.43(\mathrm{~s}, 3 \mathrm{H}) .{ }^{13} \mathrm{C} \mathrm{NMR}\left(\mathrm{CDCl}_{3}, 100 \mathrm{MHz}\right): \delta 152.43,152.16$, $144.17,138.07,131.47,129.34,129.17,129.08,126.70,126.40,125.73$, 121.42, 118.68, 60.91, 15.42. HRMS calcd for $\mathrm{C}_{17} \mathrm{H}_{14} \mathrm{~N}_{4} \mathrm{~S}_{2}[\mathrm{M}+\mathrm{H}]^{+}$ 339.0738 , found 339.0754 .
4-(1-Methyl-1H-imidazol-5-yl)-1-[(4-methyl-5-thiazolyl)phenylmethyl]-1H-1,2,3-triazole (5h). 5-Ethynyl-1-methyl-1H-imidazole was reacted with 3 to give 5 h. ${ }^{1} \mathrm{H}$ NMR $\left(\mathrm{CDCl}_{3}, 400 \mathrm{MHz}\right): \delta$ $8.75(\mathrm{~s}, 1 \mathrm{H}), 7.70(\mathrm{~s}, 1 \mathrm{H}), 7.50(\mathrm{bs}, 2 \mathrm{H}), 7.39-7.40(\mathrm{~m}, 3 \mathrm{H}), 7.31(\mathrm{~s}$, $1 \mathrm{H}), 7.17-7.19(\mathrm{~m}, 2 \mathrm{H}), 3.93(\mathrm{~s}, 3 \mathrm{H}), 2.44(\mathrm{~s}, 3 \mathrm{H}) .{ }^{13} \mathrm{C}$ NMR $\left(\mathrm{CDCl}_{3}, 100 \mathrm{MHz}\right): \delta 152.50,151.87,137.66,129.04,128.99,128.90$, $126.52,120.21,60.89,15.22$. HRMS calcd for $\mathrm{C}_{17} \mathrm{H}_{16} \mathrm{~N}_{6} \mathrm{~S}[\mathrm{M}+\mathrm{H}]^{+}$ 337.1235 , found 337.1235.

1-[(4-Methyl-5-thiazolyl)phenylmethyl]-1H-1,2,3-triazole (5i). Ethynyltrimethylsilane was reacted with 3 in the presence of $\mathrm{CuSO}_{4}$, sodium ascorbate, and $\mathrm{K}_{2} \mathrm{CO}_{3}$ to give $5 \mathrm{i}$. ${ }^{1} \mathrm{H}$ NMR (acetone$\left.d_{6}, 400 \mathrm{MHz}\right): \delta 8.90(\mathrm{~s}, 1 \mathrm{H}), 8.06(\mathrm{~d}, 1 \mathrm{H}, J=0.8 \mathrm{~Hz}), 7.75(\mathrm{~s}, 1 \mathrm{H}, J=$ $0.8 \mathrm{~Hz}), 7.57(\mathrm{~s}, 1 \mathrm{H}), 7.26-7.43(\mathrm{~m}, 5 \mathrm{H}), 2.37(\mathrm{~s}, 3 \mathrm{H}) .{ }^{13} \mathrm{C}$ NMR (acetone- $\left.d_{6}, 100 \mathrm{MHz}\right): \delta 153.57,152.41,140.39,134.11,130.73$, $129.73,129.42,127.71,125.00,61.00,15.35$. HRMS calcd for $\mathrm{C}_{13} \mathrm{H}_{12} \mathrm{~N}_{4} \mathrm{~S}[\mathrm{M}+\mathrm{H}]^{+}$257.0861, found 257.0873.

1-(4-Methyl-5-thiazolyl)-1-(4-fluorophenyl)methanol (6a). 4Fluorophenylmagnesium bromide was reacted with $\mathbf{1}$ to give $\mathbf{6 a}$ according to the method described for compound 2 . ${ }^{1} \mathrm{H}$ NMR $\left(\mathrm{CDCl}_{3}, 400 \mathrm{MHz}\right): \delta 8.49(\mathrm{~s}, 1 \mathrm{H}), 7.33-7.37(\mathrm{~m}, 2 \mathrm{H}), 7.03(\mathrm{t}, 2 \mathrm{H}, J$ $=8.4 \mathrm{~Hz}), 6.04(\mathrm{~s}, 1 \mathrm{H}), 2.32(\mathrm{~s}, 3 \mathrm{H})$. HRMS calcd for $\mathrm{C}_{11} \mathrm{H}_{10}$ FNOS $[\mathrm{M}+\mathrm{H}]^{+} 224.0545$, found 224.0544 .

1-(4-Methyl-5-thiazolyl)-1-(4-chlorophenyl)methanol (6b). 4Chlorophenylmagnesium bromide was reacted with $\mathbf{1}$ to give $\mathbf{6 b}$ according to the method described for compound $2 .{ }^{1} \mathrm{H}$ NMR $\left(\mathrm{CDCl}_{3}, 400 \mathrm{MHz}\right): \delta 8.56$ (s, 3H), 7.33 (bs, $\left.4 \mathrm{H}\right), 6.07$ (s, $\left.1 \mathrm{H}\right), 2.38$ (s, 3H). HRMS calcd for $\mathrm{C}_{11} \mathrm{H}_{10}$ ClNOS $[\mathrm{M}+\mathrm{H}]^{+} 240.0250$, found 240.0245 .

5-[Azido(4-fluorophenyl)methyl]-4-methylthiazole (7). 6a was used to prepare 7 according to the method described for compound 3. ${ }^{1} \mathrm{H}$ NMR $\left(\mathrm{CDCl}_{3}, 400 \mathrm{MHz}\right): \delta 8.69(\mathrm{~s}, 1 \mathrm{H}), 7.27-7.34$ $(\mathrm{m}, 2 \mathrm{H}), 7.07(\mathrm{t}, 2 \mathrm{H}, J=8.4 \mathrm{~Hz}), 5.98(\mathrm{~s}, 1 \mathrm{H}), 2.43(\mathrm{~s}, 3 \mathrm{H}) .{ }^{13} \mathrm{C} \mathrm{NMR}$ $\left(\mathrm{CDCl}_{3}, 100 \mathrm{MHz}\right): \delta 163.82,161.35,151.85,150.28,134.43,134.40$, $130.92,128.60,128.52,115.98,115.77,60.74,15.49$.

3-[1-[(4-Fluorophenyl)(4-methyl-5-thiazolyl)methyl]-1 H1,2,3-triazol-4-yl]pyridine (8). 3-Ethylnylpyridine was reacted with 7 to give 8 using a method described for compound $5 .{ }^{1} \mathrm{H}$ NMR $\left(\mathrm{CDCl}_{3}, 400 \mathrm{MHz}\right): \delta 8.99(\mathrm{~s}, 1 \mathrm{H}), 8.77(\mathrm{~s}, 1 \mathrm{H}), 8.56(\mathrm{~d}, 1 \mathrm{H}, J=3.6$ $\mathrm{Hz}), 8.18-8.21(\mathrm{~m}, 1 \mathrm{H}), 7.88(\mathrm{~s}, 1 \mathrm{H}), 7.34-7.37(\mathrm{~m}, 2 \mathrm{H}), 7.17-7.20$ (m, 2H), 7.06-7.11 (m, 2H), $2.44(\mathrm{~s}, 3 \mathrm{H}) .{ }^{13} \mathrm{C} \mathrm{NMR}\left(\mathrm{CDCl}_{3}, 100\right.$ $\mathrm{MHz}): \delta 163.97,161.49,152.59,152.09,149.33,146.89,144.89$, $113.71,113.68,132.89,128.79,128.61,128.53,126.16,123.60,119.27$, 116.26, 116.04, 60.42, 15.30. . HRMS calcd for $\mathrm{C}_{18} \mathrm{H}_{14} \mathrm{FN}_{5} \mathrm{~S}[\mathrm{M}+\mathrm{H}]^{+}$ 352.1032 , found 352.1040 .

5-(2-Azidoethyl)-4-methylthiazole (10). $\mathrm{MsCl}$ (2.1 g, 18.1 $\mathrm{mmol}$ ) was added to a solution of 9 and DIPEA (3.7 mL, 22.3 $\mathrm{mmol})$ in anhydrous acetonitrile $(100 \mathrm{~mL})$. Reaction was monitored by TLC until the starting material was consumed. $\mathrm{NaN}_{3}(2.7 \mathrm{~g}, 41.9$ mmol) was added, and the mixture was refluxed for $3 \mathrm{~h}$. Most of the acetonitrile was removed under reduced pressure. The residue was diluted with ethyl acetate and washed with water. The organic phase was separated and concentrated, and the crude product was purified by column chromatography. Product was obtained as a slightly yellow oil. ${ }^{1} \mathrm{H}$ NMR (acetone- $\left.d_{6}, 400 \mathrm{MHz}\right): \delta 8.74(\mathrm{~s}, 1 \mathrm{H}), 3.59(\mathrm{t}, 2 \mathrm{H}, J=6.8$ $\mathrm{Hz}), 3.09(\mathrm{t}, 2 \mathrm{H}, J=6.8 \mathrm{~Hz}), 2.38(\mathrm{~s}, 3 \mathrm{H}) .{ }^{13} \mathrm{C}$ NMR (acetone- $d_{6}, 100$ $\mathrm{MHz}): \delta 150.75,128.19,52.72,26.54,14.96$.

Compound 11. 11a-c were synthesized using the method described for compound 5 .

1-[2-(4-Methyl-5-thiazolyl)ethyl]-1H-1,2,3-triazole (11a). Ethynyltrimethylsilane was reacted with $\mathbf{1 0}$ in the presence of $\mathrm{CuSO}_{4}$, sodium ascorbate, and $\mathrm{K}_{2} \mathrm{CO}_{3}$ to give 11a. ${ }^{1} \mathrm{H}$ NMR (acetone- $\left.d_{6}, 400 \mathrm{MHz}\right): \delta 8.70(\mathrm{~s}, 1 \mathrm{H}), 7.83(\mathrm{~s}, 1 \mathrm{H}), 7.62(\mathrm{~s}, 1 \mathrm{H})$, $4.68(\mathrm{t}, 2 \mathrm{H}, J=6.8 \mathrm{~Hz}), 3.45(\mathrm{t}, 2 \mathrm{H}, J=6.8 \mathrm{~Hz}), 2.18(\mathrm{~s}, 3 \mathrm{H}) .{ }^{13} \mathrm{C}$ NMR (acetone- $\left.d_{6}, 100 \mathrm{MHz}\right): \delta 151.12,150.93,133.81,127.25$, 125.13, 51.14, 27.68, 14.59. HRMS calcd for $\mathrm{C}_{8} \mathrm{H}_{10} \mathrm{~N}_{4} \mathrm{~S}[\mathrm{M}+\mathrm{H}]^{+}$ 195.0704, found 195.0711.

1-[2-(4-Methyl-5-thiazolyl)ethyl]-4-phenyl-1 $\mathrm{H}$-1,2,3-triazole (11b). Ethynylbenzene was reacted with 10 to give $11 \mathrm{~b} .{ }^{1} \mathrm{H}$ NMR $\left(\mathrm{CDCl}_{3}, 400 \mathrm{MHz}\right): \delta 8.60(\mathrm{~s}, 1 \mathrm{H}), 7.76-7.78(\mathrm{~m}, 2 \mathrm{H}), 7.51(\mathrm{~s}, 1 \mathrm{H})$, $7.39-7.43(\mathrm{~m}, 2 \mathrm{H}), 7.31-7.35(\mathrm{~m}, 1 \mathrm{H}), 4.60(\mathrm{t}, 2 \mathrm{H}, J=6.8 \mathrm{~Hz}), 3.44$ 
$(\mathrm{t}, 2 \mathrm{H}, J=6.8 \mathrm{~Hz}), 2.25(\mathrm{~s}, 3 \mathrm{H}) \cdot{ }^{13} \mathrm{C} \mathrm{NMR}\left(\mathrm{CDCl}_{3}, 100 \mathrm{MHz}\right): \delta$ $150.73,150.32,147.78,130.32,128.80,128.20,125.84,125.69,119.94$, 51.06, 27.34, 14.58. HRMS calcd for $\mathrm{C}_{14} \mathrm{H}_{14} \mathrm{~N}_{4} \mathrm{~S}[\mathrm{M}+\mathrm{H}]^{+}$271.1017, found 271.1015 .

3-[1-[2-(4-Methyl-5-thiazolyl)ethyl]-1H-1,2,3-triazol-4-yl]pyridine (11c). 3-Ethynylpyridine was reacted with 10 to give 11c. ${ }^{1} \mathrm{H}$ NMR $\left(\mathrm{CDCl}_{3}, 400 \mathrm{MHz}\right): \delta 8.95(\mathrm{~s}, 1 \mathrm{H}), 8.61(\mathrm{~s}, 1 \mathrm{H}), 8.56(\mathrm{~d}$, $1 \mathrm{H}, J=3.6 \mathrm{~Hz}), 8.13-8.15(\mathrm{~m}, 1 \mathrm{H}), 7.70(\mathrm{~s}, 1 \mathrm{H}), 7.34-7.37(\mathrm{~m}, 1 \mathrm{H})$, $4.64(\mathrm{t}, 2 \mathrm{H}, J=6.8 \mathrm{~Hz}), 3.47(\mathrm{t}, 2 \mathrm{H}, J=6.8 \mathrm{~Hz}), 2.26(\mathrm{~s}, 3 \mathrm{H}) .{ }^{13} \mathrm{C}$ NMR $\left(\mathrm{CDCl}_{3}, 100 \mathrm{MHz}\right): \delta 150.82,150.40,149.33,147.01,144.73$, $132.98,126.49,125.66,123.74,120.35,51.23,27.31,14.61$. HRMS calcd for $\mathrm{C}_{13} \mathrm{H}_{13} \mathrm{~N}_{5} \mathrm{~S}[\mathrm{M}+\mathrm{H}]^{+} 272.0970$, found 272.0965 .

3-Bromo-5-(methoxymethoxy)pyridine (13). 3-Bromo-5-hydroxypyridine $(1.0 \mathrm{~g}, 5.7 \mathrm{mmol})$ and $\mathrm{MOM}-\mathrm{Br}(0.64 \mathrm{~mL}, 6.9$ $\mathrm{mmol})$ were dissolved in $\mathrm{THF}(10 \mathrm{~mL})$. Anhydrous $\mathrm{K}_{2} \mathrm{CO}_{3}(1.5 \mathrm{~g}, 10.9$ mmol) was added, and the reaction mixture was stirred overnight. After filtration and concentration, the product was purified by column chromatography $\left(\mathrm{SiO}_{2}\right.$, hexane/ethyl acetate, $\left.3: 1,1.1 \mathrm{~g}, 88 \%\right) .{ }^{1} \mathrm{H}$ NMR $\left(\mathrm{CDCl}_{3}, 400 \mathrm{MHz}\right): \delta 8.34(\mathrm{~s}, 1 \mathrm{H}), 8.33(\mathrm{~s}, 1 \mathrm{H}), 7.56(\mathrm{t}, 1 \mathrm{H}, J$ $=2.4 \mathrm{~Hz}), 5.19(\mathrm{~s}, 2 \mathrm{H}), 3.49(\mathrm{~s}, 3 \mathrm{H}) \cdot{ }^{13} \mathrm{C}$ NMR $\left(\mathrm{CDCl}_{3}, 100 \mathrm{MHz}\right): \delta$ 153.70, 143.96, 137.81, 125.72, 120.18, 94.66, 56.27.

3-(Methoxymethoxy)-5-[2-(trimethylsilyl)ethynyl]pyridine (14). Compound 13 (1.0 g, $4.6 \mathrm{mmol})$, CuI ( $44 \mathrm{mg}, 0.23 \mathrm{mmol})$, and $\mathrm{Pd}\left(\mathrm{Ph}_{3} \mathrm{P}\right)_{2} \mathrm{Cl}_{2}(162 \mathrm{mg}, 0.23 \mathrm{mmol})$ were placed in a flask and filled with argon. THF $(10 \mathrm{~mL})$ was added using a syringe followed by $\mathrm{NEt}_{3}$ $(3.0 \mathrm{~mL}, 21 \mathrm{mmol})$ and ethynyltrimethylsilane $(0.7 \mathrm{~mL}, 5.1 \mathrm{mmol})$. The reaction mixture was stirred overnight at room temperature. Most of the solvent was removed, and the residue was purified by column chromatography $\left(\mathrm{SiO}_{2}\right.$, hexane/ethyl acetate, 5:1, $\left.0.85 \mathrm{~g}, 81 \%\right) .{ }^{1} \mathrm{H}$ NMR ( $\left.\mathrm{CDCl}_{3}, 400 \mathrm{MHz}\right): \delta 8.32-8.35(\mathrm{~m}, 2 \mathrm{H}), 7.43-7.44(\mathrm{~m}, 2 \mathrm{H})$, 5.19 (s, $2 \mathrm{H}), 3.48$ (s, 3H), $0.26(\mathrm{~s}, 9 \mathrm{H}) .{ }^{13} \mathrm{C}$ NMR $\left(\mathrm{CDCl}_{3}, 100\right.$ $\mathrm{MHz}): \delta 152.65,145.97,139.21,125.18,120.38,101.15,98.03,94.53$, 56.17.

3-(Methoxymethoxy)-5-[1-[(4-methyl-5-thiazolyl)phenylmethyl]-1H-1,2,3-triazol-4-yl]pyridine (15). Azide 3 (783 $\mathrm{mg}, 3.4 \mathrm{mmol})$ and alkyne $14(0.8 \mathrm{~g}, 3.4 \mathrm{mmol})$ were dissolved in a mixture of $\mathrm{MeOH}$ and water $(2: 1,5 \mathrm{~mL}) . \mathrm{K}_{2} \mathrm{CO}_{3}(484 \mathrm{mg}, 3.5 \mathrm{mmol})$, $\mathrm{CuSO}_{4} \cdot 5 \mathrm{H}_{2} \mathrm{O}(170 \mathrm{mg}, 0.68 \mathrm{mmol})$, and sodium ascorbate $(272 \mathrm{mg}$, $0.68 \mathrm{mmol}$ ) were added, and the reaction mixture was stirred at room temperature overnight. Most of the solvent was removed under reduced pressure. The residue was dissolved in DCM and washed with water. The organic phase was separated and concentrated, and the crude product was purified by column chromatography (DCM/ $\mathrm{MeOH}, 20: 1,1.15 \mathrm{~g}, 86 \%) .{ }^{1} \mathrm{H}$ NMR $\left(\mathrm{CDCl}_{3}, 400 \mathrm{MHz}\right): \delta 8.75(\mathrm{~s}$, $1 \mathrm{H}), 8.65(\mathrm{~s}, 1 \mathrm{H}), 8.37(\mathrm{~s}, 1 \mathrm{H}), 7.92(\mathrm{~s}, 1 \mathrm{H}), 7.90(\mathrm{~s}, 1 \mathrm{H}), 7.35-7.39$ (m, 4H), 7.18-7.20 (m, 2H), $5.24(\mathrm{~s}, 2 \mathrm{H}), 3.48(\mathrm{~s}, 3 \mathrm{H}), 2.43(\mathrm{~s}, 3 \mathrm{H})$. ${ }^{13} \mathrm{C}$ NMR $\left(\mathrm{CDCl}_{3}, 100 \mathrm{MHz}\right): \delta 153.40,152.50,151.92,144.42$, $140.07,139.05,137.69,129.01,128.96,128.92,126.79,126.51,119.70$, $119.48,94.31,60.93,56.03,15.20$.

5-[1-[(4-Methyl-5-thiazolyl)phenylmethyl]-1H-1,2,3-triazol4-yl]-3-pyridinol (16). Click product $15(230 \mathrm{mg}, 0.58 \mathrm{mmol})$ was dissolved in $\mathrm{HCl} / i-\mathrm{PrOH}$ solution $(1.5 \mathrm{M}, 5.0 \mathrm{~mL})$ and heated at 70 ${ }^{\circ} \mathrm{C}$ for $1 \mathrm{~h}$. The solvent was removed. The residue was dissolved in AcOEt and washed with aqueous $\mathrm{NaHCO}_{3}$. The organic phase was separated and concentrated, and the crude product was purified by column chromatography (DCM/MeOH, 15:1, $170 \mathrm{mg}, 83 \%) .{ }^{1} \mathrm{H}$ NMR (acetone- $\left.d_{6}, 400 \mathrm{MHz}\right): \delta 9.11(\mathrm{bs}, 1 \mathrm{H}), 8.93(\mathrm{~s}, 1 \mathrm{H}), 8.61(\mathrm{~s}$, $1 \mathrm{H}), 8.59(\mathrm{~s}, 1 \mathrm{H}), 8.17(\mathrm{~d}, 1 \mathrm{H}, J=2.8 \mathrm{~Hz}), 7.76(\mathrm{t}, 1 \mathrm{H}, J=2.4 \mathrm{~Hz})$, $7.60(\mathrm{~s}, 1 \mathrm{H}), 7.35-7.46(\mathrm{~m}, 5 \mathrm{H}), 2.41(\mathrm{~s}, 3 \mathrm{H}) .{ }^{13} \mathrm{C}$ NMR (acetone- $d_{6}$, $100 \mathrm{MHz}): \delta 154.63,153.77,152.72,145.09,140.14,139.11,138.41$, $130.41,129.83,129.56,128.41,127.78,122.09,119.22,61.50,15.43$. HRMS calcd for $\mathrm{C}_{18} \mathrm{H}_{15} \mathrm{~N}_{5} \mathrm{OS}[\mathrm{M}+\mathrm{H}]^{+} 350.1076$, found 350.1068 .

4-[5-[1-[(4-Methyl-5-thiazolyl)phenylmethyl]-1H-1,2,3-triazol-4-yl]-3-pyridinyl]oxy-1-butanol (17). 1-Acetoxy-4-hydroxybutane $(150 \mathrm{mg}, 1.2 \mathrm{mmol}), 16(200 \mathrm{mg}, 0.57 \mathrm{mmol})$, and $\mathrm{PPh}_{3}(227$ $\mathrm{mg}$ ) were dissolved in THF $(5 \mathrm{~mL})$, and the flask was filled with argon. The solution was cooled in an ice bath, and DIAD $(230 \mu \mathrm{L}, 1.1$ mmol) was added using a syringe. The mixture was stirred overnight and quenched with water. After workup, the crude product was dissolved in methanol $(10 \mathrm{~mL})$ and treated with $\mathrm{K}_{2} \mathrm{CO}_{3}(140 \mathrm{mg})$.
Solvent was removed, and the residue was dissolved in ethyl acetate and washed with water. The crude product was purified by column chromatography (DCM/MeOH, 15:1, $67 \mathrm{mg}, 28 \%$ ). ${ }^{1} \mathrm{H}$ NMR $\left(\mathrm{CDCl}_{3}, 400 \mathrm{MHz}\right): \delta 8.76(\mathrm{~s}, 1 \mathrm{H}), 8.50(\mathrm{~d}, 1 \mathrm{H}, J=0.8 \mathrm{~Hz}), 8.24$ $(\mathrm{d}, 1 \mathrm{H}, J=2.4 \mathrm{~Hz}), 7.84(\mathrm{~s}, 1 \mathrm{H}), 7.77(\mathrm{t}, 1 \mathrm{H}, J=1.6 \mathrm{~Hz}), 7.39-7.41$ $(\mathrm{m}, 3 \mathrm{H}), 7.33(\mathrm{~s}, 1 \mathrm{H}), 7.17-7.19(\mathrm{~m}, 2 \mathrm{H}), 4.10(\mathrm{t}, 2 \mathrm{H}, J=6.4 \mathrm{~Hz})$, $3.73(\mathrm{t}, 2 \mathrm{H}, J=6.4 \mathrm{~Hz}), 2.44(\mathrm{~s}, 3 \mathrm{H}), 1.89-1.94(\mathrm{~m}, 2 \mathrm{H}), 1.74-1.79$ $(\mathrm{m}, 2 \mathrm{H}) .{ }^{13} \mathrm{C} \mathrm{NMR}\left(\mathrm{CDCl}_{3}, 100 \mathrm{MHz}\right): \delta 155.30,152.60,152.09$, 144.66, 138.82, 138.13, 137.74, 129.19, 129.16, 129.06, 126.84, 126.64, $119.58,117.38,68.19,62.01,61.11,29.07,25.55,15.35$. HRMS calcd for $\mathrm{C}_{22} \mathrm{H}_{23} \mathrm{~N}_{5} \mathrm{O}_{2} \mathrm{~S}[\mathrm{M}+\mathrm{H}]^{+}$422.1645, found 422.1657.

4-[[5-[1-[(4-Methyl-5-thiazolyl)phenylmethyl]-1H-1,2,3-triazol-4-yl]-3-pyridinyl]oxybutane]-1-nitrate (18). 1-Nitrooxy-4-hydroxybutane $(25 \mathrm{mg}, 0.19 \mathrm{mmol}), 16(25 \mathrm{mg}, 0.07 \mathrm{mmol})$, and $\mathrm{PPh}_{3}$ $(37 \mathrm{mg}, 0.14 \mathrm{mmol})$ were dissolved in THF $(2 \mathrm{~mL})$, and the flask was filled with argon. The solution was cooled in an ice bath, and DIAD $(40 \mu \mathrm{L})$ was added using a syringe. The mixture was stirred overnight and quenched with water. Solvent was removed, and crude product was purified by purified by column chromatography $(\mathrm{DCM} / \mathrm{MeOH}$, 20:1, 67\%). ${ }^{1} \mathrm{H}$ NMR $\left(\mathrm{CDCl}_{3}, 400 \mathrm{MHz}\right): \delta 8.77(\mathrm{~s}, 1 \mathrm{H}), 8.53(\mathrm{~s}$, $1 \mathrm{H}), 8.26(\mathrm{~s}, 1 \mathrm{H}), 7.81(\mathrm{~s}, 1 \mathrm{H}), 7.80-7.79(\mathrm{~m}, 1 \mathrm{H}), 7.40-7.42(\mathrm{~m}$, $3 \mathrm{H}), 7.33(\mathrm{~s}, 1 \mathrm{H}), 7.17-7.19(\mathrm{~m}, 2 \mathrm{H}), 4.55(\mathrm{t}, 2 \mathrm{H}, J=6.0 \mathrm{~Hz}), 4.12$ $(\mathrm{t}, 2 \mathrm{H}, J=6.0 \mathrm{~Hz}), 2.45(\mathrm{t}, 3 \mathrm{H}), 1.95-1.97(\mathrm{~m}, 4 \mathrm{H}) .{ }^{13} \mathrm{C}$ NMR $\left(\mathrm{CDCl}_{3}, 100 \mathrm{MHz}\right): \delta 155.14,152.65,152.24,144.67,139.20,138.14$, $137.81,129.29,129.26,129.09,126.98,126.72,119.54,117.39,72.70$, $67.47,61.21,25.47,23.71,15.45$. HRMS calcd for $\mathrm{C}_{22} \mathrm{H}_{22} \mathrm{~N}_{6} \mathrm{O}_{4} \mathrm{~S}[\mathrm{M}+$ $\mathrm{H}]^{+}$467.1501, found 467.1488.

$\alpha$-(Bromomethyl)-4-methyl-5-thiazolemethanol (20). 4Methyl-5-vinylthiazole $(900 \mathrm{mg}, 7.2 \mathrm{mmol})$ was dissolved in a mixture of dioxane $(2.5 \mathrm{~mL}), \mathrm{H}_{2} \mathrm{O}(5 \mathrm{~mL})$ and acetic acid $(430 \mathrm{mg})$. NBS $(1.4$ g, $7.9 \mathrm{mmol}$ ) was added in three portions. The reaction mixture was stirred at room temperature for $1 \mathrm{~h}$ and then diluted with ethyl acetate $(50 \mathrm{~mL})$. The organic phase was separated and concentrated, and the product was purified by column chromatography $\left(\mathrm{SiO}_{2}\right.$, hexane/ethyl acetate, $1.5: 1,900 \mathrm{mg}, 52 \%) .{ }^{1} \mathrm{H}$ NMR $\left(\mathrm{CDCl}_{3}, 400 \mathrm{MHz}\right): \delta 8.64(\mathrm{~s}$, $1 \mathrm{H}), 5.22(\mathrm{t}, 1 \mathrm{H}, J=6.8 \mathrm{~Hz}), 3.57(\mathrm{~d}, 2 \mathrm{H}, J=6.8 \mathrm{~Hz}), 2.42(\mathrm{~s}, 3 \mathrm{H})$. ${ }^{13} \mathrm{C} \mathrm{NMR}\left(\mathrm{CDCl}_{3}, 100 \mathrm{MHz}\right): \delta 151.53,149.48,132.10,67.63,38.44$, 15.39.

4-Methyl-5-(2-oxiranyl)thiazole (21). Bromohydrin $20(650 \mathrm{mg}$, $2.94 \mathrm{mmol})$ was dissolved in $\mathrm{MeOH}(10 \mathrm{~mL}) . \mathrm{K}_{2} \mathrm{CO}_{3}(1.2 \mathrm{~g}, 8.8$ $\mathrm{mmol}$ ) was added, and the reaction mixture was stirred at room temperature for $1 \mathrm{~h}$. Solvent was removed under reduced pressure, and the residue was diluted with hexane and ethyl acetate $(50 \mathrm{~mL}, 2: 1 \mathrm{v} /$ v). After filtration and concentration, the product was obtained with enough purity for the next step reaction. ${ }^{1} \mathrm{H} \mathrm{NMR}\left(\mathrm{CDCl}_{3}, 400\right.$ $\mathrm{MHz}): \delta 8.63(\mathrm{~s}, 1 \mathrm{H}), 4.10(\mathrm{t}, 1 \mathrm{H}, J=3.6 \mathrm{~Hz}), 3.22-3.24(\mathrm{~m}, 1 \mathrm{H})$, 2.91-2.93 (m, $1 \mathrm{H}), 2.53(\mathrm{~s}, 3 \mathrm{H}) .{ }^{13} \mathrm{C}$ NMR $\left(\mathrm{CDCl}_{3}, 100 \mathrm{MHz}\right): \delta$ $151.90,150.69,128.97,51.25,46.80,14.95$.

$\beta$-Phenyl-4-methyl-5-thiazoleethanol (22a) and $\alpha$-(Phenylmethyl)-4-methyl-5-thiazolemethanol (23a). Crude epoxide 21 $(1.0 \mathrm{~g}, 7.1 \mathrm{mmol})$ was dissolved in anhydrous THF $(10 \mathrm{~mL})$ and added dropwise to a phenylmagnisum bromide solution ( $1 \mathrm{M}$ in THF, $10 \mathrm{~mL}$ ) at $4{ }^{\circ} \mathrm{C}$. The reaction mixture was stirred overnight at room temperature, quenched with aqueous $\mathrm{NH}_{4} \mathrm{Cl}$, and extracted with ethyl acetate $(2 \times 50 \mathrm{~mL})$. The organic phase was separated and concentrated. 22a and 23a were separated and purified by column chromatography $\left(\mathrm{SiO}_{2}\right.$, hexane/ethyl acetate 1:1). 22a (major product, $1.0 \mathrm{~g}, 65 \%),{ }^{1} \mathrm{H}$ NMR $\left(\mathrm{CDCl}_{3}, 400 \mathrm{MHz}\right): \delta 8.43(\mathrm{~s}, 1 \mathrm{H}), 7.25-7.29$ $(\mathrm{m}, 2 \mathrm{H}), 7.17-7.21(\mathrm{~m}, 3 \mathrm{H}), 4.38(\mathrm{t}, 1 \mathrm{H}, J=6.4 \mathrm{~Hz}), 3.95-4.05(\mathrm{~m}$, $2 \mathrm{H}), 3.87(\mathrm{~s}, 1 \mathrm{H}, \mathrm{OH}), 2.28(\mathrm{~s}, 3 \mathrm{H}) .{ }^{13} \mathrm{C}$ NMR $\left(\mathrm{CDCl}_{3}, 100 \mathrm{MHz}\right): \delta$ $150.11,149.87,140.13,131.48,128.92,127.91,127.33,67.13,46.27$, 15.34. HRMS calcd for $\mathrm{C}_{12} \mathrm{H}_{13} \mathrm{NOS}[\mathrm{M}+\mathrm{H}]^{+}$220.0796, found 220.0795. 23a (minor product, $0.2 \mathrm{~g}, 13 \%),{ }^{1} \mathrm{H}$ NMR $\left(\mathrm{CDCl}_{3}, 400\right.$ $\mathrm{MHz}): \delta 8.43(\mathrm{~s}, 1 \mathrm{H}), 7.28-7.33(\mathrm{~m}, 5 \mathrm{H}), 4.83(\mathrm{t}, 1 \mathrm{H}, J=6.4 \mathrm{~Hz})$, $3.29(\mathrm{~s}, 1 \mathrm{H}), 3.10-3.19(\mathrm{~m}, 2 \mathrm{H}), 2.17(\mathrm{~s}, 3 \mathrm{H}) .{ }^{13} \mathrm{C}$ NMR $\left(\mathrm{CDCl}_{3}, 100\right.$ $\mathrm{MHz}): \delta 150.07,149.89,143.23,128.42,127.82,126.95,125.77,74.36$, $36.08,14.63$. HRMS calcd for $\mathrm{C}_{12} \mathrm{H}_{13} \mathrm{NOS}[\mathrm{M}+\mathrm{H}]^{+} 220.0796$, found 220.0796 .

$\beta$-(4-Fluorophenyl)-4-methyl-5-thiazoleethanol (22b) and $\alpha$ [(4-Fluorophenyl)methyl]-4-methyl-5-thiazolemethanol (23b). 
$\mathbf{2 2 b}$ and $\mathbf{2 3 b}$ were synthesized using the procedure described above for 22a from epoxide 21 and 4-fluorophenylmagnisum bromide. Products were separated and purified by column chromatography $\left(\mathrm{SiO}_{2}\right.$, hexane/ethyl acetate, 1:1). 22b (major product, 60\%), ${ }^{1} \mathrm{H}$ NMR $\left(\mathrm{CDCl}_{3}, 400 \mathrm{MHz}\right): \delta 8.45(\mathrm{~s}, 1 \mathrm{H}), 7.16-7.19(\mathrm{~m}, 2 \mathrm{H}), 6.30-6.97$ $(\mathrm{m}, 2 \mathrm{H}), 4.37(\mathrm{t}, 1 \mathrm{H}, J=6.4 \mathrm{~Hz}), 3.94-4.03(\mathrm{~m}, 2 \mathrm{H}), 2.26(\mathrm{~s}, 3 \mathrm{H})$. ${ }^{13} \mathrm{C}$ NMR $\left(\mathrm{CDCl}_{3}, 100 \mathrm{MHz}\right): \delta 162.66,160.22,150.07,148.95$, $136.24,136.21,131.98,129.26,129.18,115.36,115.14,66.22,45.16$, 14.82. HRMS calcd for $\mathrm{C}_{12} \mathrm{H}_{12}$ FNOS $[\mathrm{M}+\mathrm{H}]^{+}$238.0702, found 238.0699. 23b (minor product, 14\%), ${ }^{1} \mathrm{H} \mathrm{NMR}\left(\mathrm{CDCl}_{3}, 400 \mathrm{MHz}\right): \delta$ $8.39(\mathrm{~s}, 1 \mathrm{H}), 7.21-7.24(\mathrm{~m}, 2 \mathrm{H}), 6.96-6.99(\mathrm{~m}, 2 \mathrm{H}), 4.81(\mathrm{t}, 1 \mathrm{H}, J=$ $6.4 \mathrm{~Hz}), 3.04-3.16(\mathrm{~m}, 2 \mathrm{H}), 2.12(\mathrm{~s}, 3 \mathrm{H}) .{ }^{13} \mathrm{C} \mathrm{NMR}\left(\mathrm{CDCl}_{3}, 100\right.$ $\mathrm{MHz}): \delta 163.50,161.06,150.25,149.84,139.14,139.11,127.51$, $127.43,126.89,115.35,115.14,73.62,36.19,14.61$. HRMS calcd for $\mathrm{C}_{12} \mathrm{H}_{12}$ FNOS $[\mathrm{M}+\mathrm{H}]^{+} 238.0702$, found 238.0709.

$\beta$-(4-Chlorophenyl)-4-methyl-5-thiazoleethanol (22c). Compound $22 \mathrm{c}$ was synthesized using the procedure described above for 22a from epoxide 21 and 4-chlorophenylmagnisum bromide (1 M in diethyl ether). Product was separated and purified by column chromatography $\left(\mathrm{SiO}_{2}\right.$, hexane/ethyl acetate, 1:1, 79\%). ${ }^{1} \mathrm{H}$ NMR $\left(\mathrm{CDCl}_{3}, 400 \mathrm{MHz}\right): \delta 8.61(\mathrm{~s}, 1 \mathrm{H}), 7.29(\mathrm{~d}, 2 \mathrm{H}, J=8.4 \mathrm{~Hz}), 7.18(\mathrm{~d}$, $2 \mathrm{H}, J=8.4 \mathrm{~Hz}), 4.42(\mathrm{t}, 1 \mathrm{H}, J=6.4 \mathrm{~Hz}), 4.03-4.07(\mathrm{~m}, 2 \mathrm{H}), 2.35(\mathrm{~s}$, $3 \mathrm{H}) .{ }^{13} \mathrm{C} \mathrm{NMR}\left(\mathrm{CDCl}_{3}, 100 \mathrm{MHz}\right): \delta 150.29,149.95,138.78,133.13$, $131.02,129.26,129.00,66.86,45.57,15.32$.

2,3,4,5-Tetrahydro-2,8-dimethyl-5-[2-(4-methyl-5-thiazolyl)ethyl]-1 $\mathrm{H}$-pyrido[4,3-b]indole (24). Caboline $(500 \mathrm{mg}, 2.5 \mathrm{mmol})$ was dissolved in DMSO (5 mL). NaH (120 mg, 60\%, $3 \mathrm{mmol}$ ) was added, and the mixture was stirred for $5 \mathrm{~min}$. 4-Methyl-5-vinylthiazole $(2.86 \mathrm{~mL}, 25 \mathrm{mmol})$ was added, and the reaction mixture was heated at $90{ }^{\circ} \mathrm{C}$ for $5 \mathrm{~h}$. Reaction was quenched with $\mathrm{MeOH}(0.5 \mathrm{~mL})$, and the solvent was evaporated under high vacuum. The residue was dissolved in DCM $(20 \mathrm{~mL})$ and washed with water. The organic phase was separated and concentrated, and the product was purified by column chromatography $\left(\mathrm{SiO}_{2}, \mathrm{DCM} / \mathrm{MeOH}, 25: 1,0.1 \% \mathrm{HOAc}, 350\right.$ $\mathrm{mg}$, yellow solid, 36\%). Compound 24 was obtained as an $\mathrm{AcOH}$ salt. ${ }^{1} \mathrm{H}$ NMR (acetone- $\left.d_{6}, 400 \mathrm{MHz}\right): \delta 8.67(\mathrm{~s}, 1 \mathrm{H}), 7.18-7.22(\mathrm{~m}, 2 \mathrm{H})$, $6.93(\mathrm{~d}, 1 \mathrm{H}, J=8.4 \mathrm{~Hz}), 4.28(\mathrm{t}, 2 \mathrm{H}, J=6.4 \mathrm{~Hz}), 3.82(\mathrm{~s}, 2 \mathrm{H}), 3.23(\mathrm{t}$, $2 \mathrm{H}, J=6.4 \mathrm{~Hz}), 2.92(\mathrm{t}, 2 \mathrm{H}, J=6.0 \mathrm{~Hz}), 2.56-2.62(\mathrm{~m}, 5 \mathrm{H}), 2.38(\mathrm{~s}$, $3 \mathrm{H}), 1.96(\mathrm{~s}, 3 \mathrm{H}), 1.91(\mathrm{~s}, 3 \mathrm{H}) .{ }^{13} \mathrm{C}$ NMR (acetone- $\left.d_{6}, 100 \mathrm{MHz}\right): \delta$ $172.71,150.34,150.75,135.69,133.51,128.69,128.35,126.83,123.21$, 118.16, 109.16, 106.11, 52.23, 51.42, 44.69, 44.22, 27.10, 21.84, 21.48, 20.89, 14.43. HRMS calcd for $\mathrm{C}_{19} \mathrm{H}_{23} \mathrm{~N}_{3} \mathrm{~S} \cdot \mathrm{CH}_{3} \mathrm{CO}_{2} \mathrm{H}[\mathrm{M}+\mathrm{H}]^{+}$ 326.1691 , found 326.1687 .

$\boldsymbol{\beta}$-Azido-4-methyl-5-thiazoleethanol (25). Epoxide 21 (400 mg, $2.8 \mathrm{mmol})$ was dissolved in acetonitrile and water $(1: 1,10 \mathrm{~mL}) . \mathrm{NaN}_{3}$ (553 mg, $8.4 \mathrm{mmol}$ ) was added. The reaction mixture was refluxed for $1 \mathrm{~h}$. Most of the solvent was removed under reduced pressure. The residue was dissolved in DCM $(20 \mathrm{~mL})$ and washed with water. The organic phase was separated and concentrated, and the crude product was purified by column chromatography $\left(\mathrm{SiO}_{2}\right.$, hexane/ethyl acetate, 1:1, $410 \mathrm{mg}, 61 \%) .{ }^{1} \mathrm{H}$ NMR $\left(\mathrm{CDCl}_{3}, 400 \mathrm{MHz}\right): \delta 8.71(\mathrm{~s}, 1 \mathrm{H})$, $4.98-5.00(\mathrm{~m}, 1 \mathrm{H}), 4.80(\mathrm{bs}, 1 \mathrm{H}), 3.76-3.87(\mathrm{~m}, 2 \mathrm{H}), 2.49(\mathrm{~s}, 3 \mathrm{H})$. ${ }^{13} \mathrm{C} \mathrm{NMR}\left(\mathrm{CDCl}_{3}, 100 \mathrm{MHz}\right): \delta 152.35,150.67,126.97,65.28,59.85$, 15.01. HRMS calcd for $\mathrm{C}_{6} \mathrm{H}_{8} \mathrm{~N}_{4} \mathrm{OS}[\mathrm{M}+\mathrm{H}]^{+}$185.0497, found 185.0508.

[1-[ $\beta$-(4-Methyl-5-thiazolyl)ethanol]-4-(3-pyridinyl)]-1 H1,2,3-triazole (26). Compound 26 was prepared according to the standard click chemistry procedure described above from 25 and 3ethynylpyridine. The crude product was purified by column chromatography $\left(\mathrm{SiO}_{2}, \mathrm{DCM} / \mathrm{MeOH}, 20: 1,95 \%\right) .{ }^{1} \mathrm{H}$ NMR $\left(\mathrm{CDCl}_{3}, 400 \mathrm{MHz}\right): \delta 9.05(\mathrm{~s}, 1 \mathrm{H}), 9.01(\mathrm{~s}, 1 \mathrm{H}), 8.80(\mathrm{~s}, 1 \mathrm{H}), 8.52$ $(\mathrm{d}, 1 \mathrm{H}, J=3.6 \mathrm{~Hz}), 8.21(\mathrm{~d}, 1 \mathrm{H}, J=8.0 \mathrm{~Hz}), 7.45(\mathrm{dd}, 1 \mathrm{H}, J=5.2 \mathrm{~Hz}$, $7.6 \mathrm{~Hz}), 6.22-6.25(\mathrm{~m}, 1 \mathrm{H}), 4.15-4.20(\mathrm{~m}, 1 \mathrm{H}), 4.04-4.08(\mathrm{~m}, 1 \mathrm{H})$, $2.44(\mathrm{~m}, 3 \mathrm{H}) .{ }^{13} \mathrm{C} \mathrm{NMR}\left(\mathrm{CDCl}_{3}, 100 \mathrm{MHz}\right): \delta 153.49,151.44$, 148.90, 146.37, 143.36, 132.42, 126.56, 126.36, 123.96, 121.73, 63.87, 58.99, 15.07. HRMS calcd for $\mathrm{C}_{13} \mathrm{H}_{13} \mathrm{~N}_{5} \mathrm{OS}[\mathrm{M}+\mathrm{H}]^{+}$288.0919, found 288.0918.

1-Nitrooxy- $\beta$-azido-(4-methyl-5-thiazoyl)ethane (27). 25 (400 mg, $2.17 \mathrm{mmol})$ was dissolved in DCM $(10 \mathrm{~mL})$ and cooled in an ice bath. Fuming nitric acid $(130 \mu \mathrm{L})$ and acetic anhydride $(245$ $\mu \mathrm{L}$ ) were added. The reaction mixture was stirred at $0-4{ }^{\circ} \mathrm{C}$ for $4 \mathrm{~h}$. After dilution with ethyl acetate $(20 \mathrm{~mL})$, the reaction mixture was neutralized by saturated aqueous $\mathrm{NaHCO}_{3}$. The organic phase was separated and concentrated, and the crude product was purified by column chromatography $\left(\mathrm{SiO}_{2}\right.$, hexane/ethyl acetate, $2.5: 1,350 \mathrm{mg}$, $71 \%) .{ }^{1} \mathrm{H}$ NMR $\left(\mathrm{CDCl}_{3}, 400 \mathrm{MHz}\right): \delta 8.79(\mathrm{~s}, 1 \mathrm{H}), 5.24(\mathrm{t}, 1 \mathrm{H}, J=$ $2.4 \mathrm{~Hz}), 4.58(\mathrm{~d}, 2 \mathrm{H}, J=6.0 \mathrm{~Hz}), 2.53(\mathrm{~s}, 3 \mathrm{H}) .{ }^{13} \mathrm{C} \mathrm{NMR}\left(\mathrm{CDCl}_{3}, 100\right.$ $\mathrm{MHz}): \delta 152.61,151.93,125.14,73.29,55.79,15.33$.

$\beta$-(4-Methyl-5-thiazolyl)-[4-(3-pyridinyl)-1 H-1,2,3-triazole-1ethane]-1-nitrate (28) and $\beta$-(4-Methyl-5-thiazolyl)-[5-(3-pyridinyl)-1 $\mathrm{H}-1,2,3$-triazole-1-ethane]-1-nitrate (29). Compound 27 $(260 \mathrm{mg}, 1.1 \mathrm{mmol})$ and 3-ethynylpyridine $(234 \mathrm{mg}, 2.2 \mathrm{mmol})$ were dissolved in toluene $(5 \mathrm{~mL})$. The reaction mixture was refluxed for 48 $h$. Toluene was removed under reduced pressure, and the residue was purified by column chromatography $\left(\mathrm{SiO}_{2}, \mathrm{DCM} / \mathrm{MeOH}, 20: 1\right) .28$ (165 mg, 44\%), ${ }^{1} \mathrm{H}$ NMR $\left(\mathrm{CDCl}_{3}, 400 \mathrm{MHz}\right): \delta 8.98(\mathrm{~s}, 1 \mathrm{H}), 8.82(\mathrm{~s}$, $1 \mathrm{H}), 8.59(\mathrm{~d}, 1 \mathrm{H}, J=3.2 \mathrm{~Hz}), 8.18(\mathrm{~d}, 1 \mathrm{H}, J=8.0 \mathrm{~Hz}), 7.91(\mathrm{~s}, 1 \mathrm{H})$, $7.37(\mathrm{dd}, 1 \mathrm{H}, J=4.8 \mathrm{~Hz}, 8.0 \mathrm{~Hz}), 6.35-6.38(\mathrm{~m}, 1 \mathrm{H}), 5.31-5.36(\mathrm{~m}$, $1 \mathrm{H}), 5.09-5.13(\mathrm{~m}, 1 \mathrm{H}), 2.56(\mathrm{~s}, 3 \mathrm{H}) .{ }^{13} \mathrm{C} \mathrm{NMR}\left(\mathrm{CDCl}_{3}, 100 \mathrm{MHz}\right)$ : $\delta 153.33,153.10,149.63,147.04,145.27,133.11,126.01,123.77$, 123.58, 119.70, 72.32, 55.41, 15.40. HRMS calcd for $\mathrm{C}_{13} \mathrm{H}_{12} \mathrm{~N}_{6} \mathrm{O}_{3} \mathrm{~S}[\mathrm{M}$ $+\mathrm{H}]^{+}$333.0764, found 333.0751. $29(120 \mathrm{mg}, 32 \%),{ }^{1} \mathrm{H}$ NMR $\left(\mathrm{CDCl}_{3}, 400 \mathrm{MHz}\right): \delta 8.80(\mathrm{dd}, 1 \mathrm{H}, J=4.8 \mathrm{~Hz}, 1.6 \mathrm{~Hz}), 8.78(\mathrm{~s}, 1 \mathrm{H})$, $8.59(\mathrm{~d}, 1 \mathrm{H}, J=1.6 \mathrm{~Hz}), 7.80(\mathrm{~s}, 1 \mathrm{H}), 7.64-7.67(\mathrm{~m}, 1 \mathrm{H}), 7.49-7.52$ $(\mathrm{m}, 1 \mathrm{H}), 5.97-6.01(\mathrm{~m}, 1 \mathrm{H}), 5.44-5.50(\mathrm{~m}, 1 \mathrm{H}), 4.98-5.02(\mathrm{~m}, 1 \mathrm{H})$, $2.24(\mathrm{~s}, 3 \mathrm{H}) .{ }^{13} \mathrm{C} \mathrm{NMR}\left(\mathrm{CDCl}_{3}, 100 \mathrm{MHz}\right): \delta 153.83,151.55,151.34$, $149.41,136.44,135.22,133.71,124.74,123.80,122.30,72.76,52.95$, 14.93. HRMS calcd for $\mathrm{C}_{13} \mathrm{H}_{12} \mathrm{~N}_{6} \mathrm{O}_{3} \mathrm{~S}[\mathrm{M}+\mathrm{H}]^{+} 333.0764$, found 333.0776.

$\beta$-(4-Methyl-5-thiazolyl)-5-(3-pyridinyl)-1 H-1,2,3-triazole-1ethanol (30). Nitrate $29(100 \mathrm{mg}, 0.3 \mathrm{mmol})$ was dissolved in $\mathrm{CH}_{3} \mathrm{CN} / \mathrm{H}_{2} \mathrm{O}(2: 1,5 \mathrm{~mL}) . \mathrm{Na}_{2} \mathrm{CO}_{3}(300 \mathrm{mg}, 3 \mathrm{mmol})$ and 2mercaptoethanol $(70 \mu \mathrm{L}, 1 \mathrm{mmol})$ were added. The reaction mixture was stirred at room temperature until most of the starting material was consumed. After dilution with DCM $(20 \mathrm{~mL})$, the solution was washed with $\mathrm{H}_{2} \mathrm{O}$ and concentrated. The crude product was purified with column chromatography (DCM/MeOH, 20:1, 81\%). ${ }^{1} \mathrm{H}$ NMR $\left(\mathrm{CDCl}_{3}, 400 \mathrm{MHz}\right): \delta 8.73(\mathrm{~d}, 1 \mathrm{H}, J=4.0 \mathrm{~Hz}), 8.66(\mathrm{bs}, 2 \mathrm{H}), 7.76-$ $7.77(\mathrm{~m}, 1 \mathrm{H}), 7.72(\mathrm{~s}, 1 \mathrm{H}), 7.45-7.49(\mathrm{~m}, 1 \mathrm{H}), 5.85-5.88(\mathrm{~m}, 1 \mathrm{H})$, 4.65-4.71 (m, 1H), 4.18-4.22 (m, 1H), $2.14(\mathrm{~s}, 3 \mathrm{H}) .{ }^{13} \mathrm{C}$ NMR $\left(\mathrm{CDCl}_{3}, 100 \mathrm{MHz}\right): \delta 152.97,150.91,150.65,149.63,136.91,135.65$, $133.38,126.45,123.79,122.96,65.62,58.02,14.96$. HRMS calcd for $\mathrm{C}_{13} \mathrm{H}_{13} \mathrm{~N}_{5} \mathrm{OS}[\mathrm{M}+\mathrm{H}]^{+}$288.0919, found 288.0916.

$\beta$-[4-(3-Pyridyl)phenyl]-4-methyl-5-thiazoleethanol (31). 22c (350 mg, $1.4 \mathrm{mmol})$, 3-pyridineboronic acid $(270 \mathrm{mg}, 2.2 \mathrm{mmol})$, $\mathrm{Pd}(\mathrm{OAc})_{2}(15 \mathrm{mg})$, (2-biphenyl)di-tert-butylphosphine $(41 \mathrm{mg})$, and KF (240 mg, $4.1 \mathrm{mmol})$ were placed in a flask filled with argon. DMF $(10 \mathrm{~mL})$ was added using a syringe. The mixture was heated at $120^{\circ} \mathrm{C}$ for $1 \mathrm{~h}$. DMF was removed under vacuum, and the residue was diluted with DCM $(50 \mathrm{~mL})$ and washed with water. The crude product was purified with column chromatography (DCM/MeOH, 20:1, 58\%). ${ }^{1} \mathrm{H}$ NMR ( $\left.\mathrm{CDCl}_{3}, 400 \mathrm{MHz}\right): \delta 8.57-8.60(\mathrm{~m}, 2 \mathrm{H}), 8.47(\mathrm{~d}, 1 \mathrm{H}, J=3.6$ $\mathrm{Hz}), 7.80(\mathrm{~d}, 1 \mathrm{H}, J=7.6 \mathrm{~Hz}), 7.47(\mathrm{~d}, 2 \mathrm{H}, J=8.0 \mathrm{~Hz}), 7.31-7.37(\mathrm{~d}$, $3 \mathrm{H}), 4.50(\mathrm{t}, 1 \mathrm{H}, J=6.0 \mathrm{~Hz}), 4.09-4.18(\mathrm{~m}, 2 \mathrm{H}), 2.38(\mathrm{~s}, 3 \mathrm{H}) .{ }^{13} \mathrm{C}$ NMR $\left(\mathrm{CDCl}_{3}, 100 \mathrm{MHz}\right): \delta 150.18,149.57,147.96,147.61,140.81$, $136.27,136.03,134.38,131.51,128.74,127.30,123.57,66.62,45.98$, 15.26. HRMS calcd for $\mathrm{C}_{17} \mathrm{H}_{16} \mathrm{~N}_{2} \mathrm{OS}[\mathrm{M}+\mathrm{H}]^{+}$297.1062, found 297.1071.

$\beta$-Phenyl-(4-methyl-5-thiazolyl)ethane-1-nitrate (32a). 22a $(150 \mathrm{mg}, 0.68 \mathrm{mmol})$ was dissolved in DCM $(3 \mathrm{~mL})$ and cooled in an ice bath. Fuming nitric acid $(120 \mu \mathrm{L})$ and acetic anhydride $(280$ $\mu \mathrm{L}$ ) were added. The reaction mixture was stirred at $0-4{ }^{\circ} \mathrm{C}$ for $4 \mathrm{~h}$. After dilution with ethyl acetate $(20 \mathrm{~mL})$, the reaction mixture was neutralized by saturated aqueous $\mathrm{NaHCO}_{3}$. The organic phase was separated and concentrated, and the crude product was purified by column chromatography $\left(\mathrm{SiO}_{2}\right.$, hexane/ethyl acetate, 3:1, $110 \mathrm{mg}$, 61\%). ${ }^{1} \mathrm{H}$ NMR $\left(\mathrm{CDCl}_{3}, 400 \mathrm{MHz}\right): \delta 8.64(\mathrm{~s}, 1 \mathrm{H}), 7.25-7.37(\mathrm{~m}$, $5 \mathrm{H}), 4.89-4.94(\mathrm{~m}, 1 \mathrm{H}), 4.80-4.85(\mathrm{~m}, 1 \mathrm{H}), 4.68(\mathrm{t}, 1 \mathrm{H}, J=7.2 \mathrm{~Hz})$, $2.40(\mathrm{~s}, 3 \mathrm{H}) .{ }^{13} \mathrm{C} \mathrm{NMR}\left(\mathrm{CDCl}_{3}, 100 \mathrm{MHz}\right): \delta 150.35,150.21,138.33$, 
130.04, 129.06, 127.86, 127.49, 75.02, 41.34, 15.21. HRMS calcd for $\mathrm{C}_{12} \mathrm{H}_{12} \mathrm{~N}_{2} \mathrm{O}_{3} \mathrm{~S}[\mathrm{M}+\mathrm{H}]^{+}$265.0647, found 265.0657.

$\beta$-(4-Fluorophenyl)-(4-methyl-5-thiazolyl)ethane-1-nitrate (32b). Compound 32b was prepared from $22 b$ as described for 32a. Product was purified by column chromatography $\left(\mathrm{SiO}_{2}\right.$, hexane/ethyl acetate, 3:1, 69\%). ${ }^{1} \mathrm{H}$ NMR $\left(\mathrm{CDCl}_{3}, 400 \mathrm{MHz}\right): \delta 8.68(\mathrm{~s}, 1 \mathrm{H})$, 7.21-7.27 (m, 2H), 7.03-7.07 (m, 2H), 4.86-4.91 (m, 1H), 4.79$4.84(\mathrm{~m}, 1 \mathrm{H}), 4.68(\mathrm{t}, 1 \mathrm{H}, J=7.2 \mathrm{~Hz}), 2.40(\mathrm{~s}, 3 \mathrm{H}) .{ }^{13} \mathrm{C}$ NMR $\left(\mathrm{CDCl}_{3}, 100 \mathrm{MHz}\right): \delta 163.39,160.93,150.56,150.27,134.18,134.14$ $129.83,129.25,129.17,116.17,115.95,74.85,40.69,15.22$. HRMS calcd for $\mathrm{C}_{12} \mathrm{H}_{11} \mathrm{FN}_{2} \mathrm{O}_{3} \mathrm{~S}[\mathrm{M}+\mathrm{H}]^{+} 283.0553$, found 283.0565 .

$\alpha$-(Phenylmethyl)-(4-methyl-5-thiazolyl)methanenitrate (33). Compound 33 was prepared from 23a as described for 32a (86\%). ${ }^{1} \mathrm{H}$ NMR $\left(\mathrm{CDCl}_{3}, 400 \mathrm{MHz}\right): \delta 8.55(\mathrm{~s}, 1 \mathrm{H}), 7.32-7.34(\mathrm{~m}$, $3 \mathrm{H}), 7.26-7.28(\mathrm{~m}, 2 \mathrm{H}), 5.88(\mathrm{t}, 1 \mathrm{H}, J=7.2 \mathrm{~Hz}), 3.38-3.44(\mathrm{~m}, 1 \mathrm{H})$, 3.24-3.29 (m, 1H), $2.22(\mathrm{~s}, 3 \mathrm{H}) \cdot{ }^{13} \mathrm{C}$ NMR $\left(\mathrm{CDCl}_{3}, 100 \mathrm{MHz}\right): \delta$ $150.90,150.41,136.15,129.12,128.66,126.22,124.04,84.51,31.27$, 14.51. HRMS calcd for $\mathrm{C}_{12} \mathrm{H}_{12} \mathrm{~N}_{2} \mathrm{O}_{3} \mathrm{~S}[\mathrm{M}+\mathrm{H}]^{+}$265.0647, found 265.0657.

1-[(Nitrooxy)methyl]cyclopropanemethanol (34). 1,1-Bis(hydroxymethyl)cyclopropane $(5.0 \mathrm{~g}, 48.9 \mathrm{mmol})$ was dissolved in DCM $(100 \mathrm{~mL})$ and cooled in an ice bath. Fuming nitric acid $(2.5$ $\mathrm{mL})$ followed by acetic anhydride $(5 \mathrm{~mL})$ was added slowly. The mixture was stirred at $4{ }^{\circ} \mathrm{C}$ for $4 \mathrm{~h}$ and quenched by aqueous $\mathrm{NaHCO}_{3}$. The organic phase was separated and washed with water. The crude product was purified by column chromatography (hexanes/ ethyl acetate, 4:1, $1.2 \mathrm{~g}, 17 \%$ ). ${ }^{1} \mathrm{H}$ NMR (acetone- $d_{6}, 400 \mathrm{MHz}$ ): $\delta$ $4.53(\mathrm{~s}, 2 \mathrm{H}), 3.44(\mathrm{~s}, 2 \mathrm{H}), 0.59-0.66(\mathrm{~m}, 4 \mathrm{H}) .{ }^{13} \mathrm{C}$ NMR (acetone- $d_{6}$, $100 \mathrm{MHz}):$ 78.35, 65.36, 21.35, 8.92.

1-[(Nitrooxy)methyl]cyclopropanecarboxylic Acid (35). Compound $34(1.9 \mathrm{~g}, 12.9 \mathrm{mmol})$ was dissolved in DCM (100 $\mathrm{mL})$. TEMPO $(0.4 \mathrm{~g}, 2.6 \mathrm{mmol})$ and $\mathrm{PhI}(\mathrm{OAc})_{2}(4.5 \mathrm{~g}, 14.2 \mathrm{mmol})$ were added successively. The reaction mixture was stirred until the alcohol was no longer detectable by TLC. The reaction mixture was washed with aqueous $\mathrm{Na}_{2} \mathrm{~S}_{2} \mathrm{O}_{3}, \mathrm{NaHCO}_{3}$, and $\mathrm{H}_{2} \mathrm{O}$. The organic phase was separated and concentrated. The residue was purified by column chromatography (hexanes/ethyl acetate, 2:1). The starting material was oxidized to an aldehyde as a white solid $(1.3 \mathrm{~g}, 70 \%) .{ }^{1} \mathrm{H}$ NMR (acetone- $\left.d_{6}, 400 \mathrm{MHz}\right): \delta 8.84(\mathrm{~s}, 1 \mathrm{H}), 4.78(\mathrm{~s}, 2 \mathrm{H}), 1.36-1.47$ $(\mathrm{m}, 4 \mathrm{H}) .{ }^{13} \mathrm{C}$ NMR (acetone- $\left.d_{6}, 100 \mathrm{MHz}\right): 199.35,74.15,30.35$, 12.56. The aldehyde $(1.1 \mathrm{~g}, 7.6 \mathrm{mmol})$ and 2-methyl-2-butene $(8.8$ $\mathrm{mL})$ were dissolved in $t$ - $\mathrm{BuOH}(50 \mathrm{~mL}) . \mathrm{NaH}_{2} \mathrm{PO}_{4} \cdot \mathrm{H}_{2} \mathrm{O}(10.0 \mathrm{~g})$ and $\mathrm{NaClO}_{2}(9.0 \mathrm{~g})$ were mixed with $\mathrm{H}_{2} \mathrm{O}(25 \mathrm{~mL})$, and then the mixture was added to the $t-\mathrm{BuOH}$ solution. The reaction mixture was stirred overnight. Solvent was removed under reduced pressure, and the residue was diluted with ethyl acetate $(200 \mathrm{~mL})$ and washed with aqueous $\mathrm{Na}_{2} \mathrm{~S}_{2} \mathrm{O}_{3}(25 \mathrm{~mL}), \mathrm{NaHCO}_{3}(25 \mathrm{~mL})$, and $\mathrm{H}_{2} \mathrm{O}(2 \times 40$ $\mathrm{mL})$. The organic phase was separated, dried over anhydrous $\mathrm{MgSO}_{4}$, and concentrated. Product was obtained as a white solid (1.1 g, 90\%). ${ }^{1} \mathrm{H}$ NMR (acetone- $\left.d_{6}, 400 \mathrm{MHz}\right): \delta 10.3(\mathrm{bs}, 1 \mathrm{H}), 4.73(\mathrm{~s}, 2 \mathrm{H}), 1.36-$ $1.40(\mathrm{~m}, 2 \mathrm{H}), 1.16-1.20(\mathrm{~m}, 2 \mathrm{H}) .{ }^{13} \mathrm{C}$ NMR (acetone- $\left.d_{6}, 100 \mathrm{MHz}\right)$ : 174.21, 76.96, 21.58, 14.48 .

[1-[(Nitrooxy)methyl]cyclopropanecarboxyl]-[(4-methyl-5thiazolyl)phenylmethyl] Ester (36). Compounds 2 (236 mg, 1.15 $\mathrm{mmol})$ and $35(222 \mathrm{mg}, 1.38 \mathrm{mmol})$ were dissolved in a mixture of DCM $(5 \mathrm{~mL})$ and DIPEA $(570 \mu \mathrm{L})$. EDCI $(330 \mathrm{mg}, 1.7 \mathrm{mmol})$, HOBt $(233 \mathrm{mg}, 1.7 \mathrm{mmol}$ ), and DMAP (15 mg, $0.13 \mathrm{mmol}$ ) were added. The reaction mixture was stirred overnight and then diluted with ethyl acetate $(50 \mathrm{~mL})$ and washed with water. The organic phase was separated and concentrated, and the crude product was purified by column chromatography $\left(\mathrm{SiO}_{2}\right.$, hexane/ethyl acetate, $2: 1,160 \mathrm{mg}$, 40\%). ${ }^{1} \mathrm{H}$ NMR $\left(\mathrm{CDCl}_{3}, 400 \mathrm{MHz}\right): \delta 8.66(\mathrm{~s}, 1 \mathrm{H}), 7.29-7.39(\mathrm{~m}$, $5 \mathrm{H}), 7.15(\mathrm{~s}, 1 \mathrm{H}), 4.62-4.68(\mathrm{~m}, 2 \mathrm{H}), 2.48(\mathrm{~s}, 3 \mathrm{H}), 1.45-1.52(\mathrm{~m}$, $2 \mathrm{H}), 1.06-1.10(\mathrm{~m}, 2 \mathrm{H}) .{ }^{13} \mathrm{C} \mathrm{NMR}\left(\mathrm{CDCl}_{3}, 100 \mathrm{MHz}\right): \delta 170.67$, $151.94,150.66,138.77,130.72,128.76,128.50,126.06,75.06,71.18$, $21.54,15.39,14.85,14.78$. HRMS calcd for $\mathrm{C}_{16} \mathrm{H}_{16} \mathrm{~N}_{2} \mathrm{O}_{5} \mathrm{~S}[\mathrm{M}+\mathrm{H}]^{+}$ 349.0858 , found 349.0854 .

[1-Methylcyclopropanecarboxyl]-[(4-methyl-5-thiazolyl)phenylmethyl] Ester (37). Compound 37 was prepared from 2 and 1-methylcyclopropane-1-carboxylic acid as described for $36(85 \%) .{ }^{1} \mathrm{H}$
$\operatorname{NMR}\left(\mathrm{CDCl}_{3}, 400 \mathrm{MHz}\right): \delta 8.65(\mathrm{~s}, 1 \mathrm{H}), 7.31-7.38(\mathrm{~m}, 5 \mathrm{H}), 7.12(\mathrm{~s}$, $1 \mathrm{H}), 2.49(\mathrm{~s}, 3 \mathrm{H}), 1.35(\mathrm{~s}, 3 \mathrm{H}), 1.28-1.32(\mathrm{~m}, 2 \mathrm{H}), 0.72-0.76(\mathrm{~m}$, $2 \mathrm{H}) .{ }^{13} \mathrm{C}$ NMR $\left(\mathrm{CDCl}_{3}, 100 \mathrm{MHz}\right): \delta 174.50,151.68,150.40,139.54$, $131.62,128.70,128.29,126.19,70.16,19.28,18.70,17.03,17.00$, 15.50. HRMS calcd for $\mathrm{C}_{16} \mathrm{H}_{17} \mathrm{NO}_{2} \mathrm{~S}[\mathrm{M}+\mathrm{H}]^{+}$288.1058, found 288.1070 .

5-(Methoxyphenylmethyl)-4-methylthiazole (38). To a solution of $2(200 \mathrm{mg}, 0.87 \mathrm{mmol})$ in DMF $(4 \mathrm{~mL})$ was added $\mathrm{NaH}(52$ $\mathrm{mg}, 60 \%, 0.87 \mathrm{mmol})$. The reaction mixture was stirred at room temperature for $15 \mathrm{~min} . \mathrm{CH}_{3} \mathrm{I}(65 \mu \mathrm{L}, 1 \mathrm{mmol})$ was added, and the reaction mixture was stirred for another $3 \mathrm{~h}$. The reaction was quenched with $\mathrm{MeOH}(1 \mathrm{~mL})$, and then most of the solvent was removed under vacuum. The residue was dissolved in ethyl acetate (50 $\mathrm{mL}$ ) and washed with water. The organic phase was separated and concentrated. The crude product was purified by column chromatography $\left(\mathrm{SiO}_{2}\right.$, hexane/ethyl acetate, $\left.2: 1,150 \mathrm{mg}, 70 \%\right) .{ }^{1} \mathrm{H}$ NMR (acetone- $\left.d_{6}, 400 \mathrm{MHz}\right): \delta 8.80(\mathrm{~s}, 1 \mathrm{H}), 7.42-7.44(\mathrm{~m}, 2 \mathrm{H}), 7.35-7.39$ $(\mathrm{m}, 2 \mathrm{H}), 7.27-7.31(\mathrm{~m}, 1 \mathrm{H}), 5.68(\mathrm{~s}, 1 \mathrm{H}), 3.34(\mathrm{~s}, 3 \mathrm{H}), 2.43(\mathrm{~s}, 3 \mathrm{H})$. HRMS calcd for $\mathrm{C}_{12} \mathrm{H}_{13} \mathrm{NOS}[\mathrm{M}+\mathrm{H}]^{+} 220.0796$, found 220.0792 .

5-[[2-(2-Bromoethoxy)ethoxy]phenylmethyl]-4-methylthiazole (39). To a solution of $2(500 \mathrm{mg}, 2.4 \mathrm{mmol})$ in DMF $(5 \mathrm{~mL})$ was added $\mathrm{NaH}(117 \mathrm{mg}, 2.92 \mathrm{mmol})$. The reaction mixture was stirred at room temperature for $15 \mathrm{~min}$. Bis(2-bromomethyl) ether $(2.2 \mathrm{~g}, 9.6$ $\mathrm{mmol}$ ) was added, and the reaction mixture was stirred for another 3 h. The reaction was quenched with $\mathrm{MeOH}(1 \mathrm{~mL})$, and then most of the solvent was removed. The residue was dissolved in ethyl acetate $(50 \mathrm{~mL})$ and washed with water. The organic phase was separated and concentrated. The crude product was purified by column chromatography $\left(\mathrm{SiO}_{2}\right.$, hexane/ethyl acetate, 2:1, $\left.740 \mathrm{mg}, 86 \%\right) .{ }^{1} \mathrm{H}$ NMR $\left(\mathrm{CDCl}_{3}, 300 \mathrm{MHz}\right): \delta 8.65(\mathrm{~s}, 1 \mathrm{H}), 7.26-7.39(\mathrm{~m}, 5 \mathrm{H}), 5.75(\mathrm{~s}, 1 \mathrm{H})$, $3.81(\mathrm{t}, 2 \mathrm{H}, J=6.1 \mathrm{~Hz}), 3.62-3.73(\mathrm{~m}, 4 \mathrm{H}), 3.46(\mathrm{t}, 2 \mathrm{H}, J=6.1 \mathrm{~Hz})$, $2.45(\mathrm{~s}, 3 \mathrm{H}) .{ }^{13} \mathrm{C} \mathrm{NMR}\left(\mathrm{CDCl}_{3}, 100 \mathrm{MHz}\right): \delta 151.50,149.60,140.83$ $133.74,128.60,128.09,126.58,77.31,71.25,70.65,68.36,30.45$, 15.57 .

1-Nitrooxy-2-[2-[(4-methyl-5-thiazolyl)phenylmethoxy]ethoxy]ethane (40). Silver nitrate $(2.0 \mathrm{~g}, 11.8 \mathrm{mmol})$ was added to a solution of $39(1.1 \mathrm{~g}, 3.1 \mathrm{mmol})$ in $\mathrm{CH}_{3} \mathrm{CN}(15 \mathrm{~mL})$. The reaction was refluxed for $2 \mathrm{~h}$ and then diluted with ethyl acetate $(50 \mathrm{~mL})$. After filtration and concentration, the crude product was purified by column chromatography $\left(\mathrm{SiO}_{2}\right.$, hexane/ethyl acetate, $\left.1.5: 1,720 \mathrm{mg}, 69 \%\right) .{ }^{1} \mathrm{H}$ $\operatorname{NMR}\left(\mathrm{CDCl}_{3}, 400 \mathrm{MHz}\right): \delta 8.62(\mathrm{~s}, 1 \mathrm{H}), 7.26-7.38(\mathrm{~m}, 5 \mathrm{H}), 4.59(\mathrm{t}$, $2 \mathrm{H}, J=4.4 \mathrm{~Hz}), 3.77(\mathrm{t}, 2 \mathrm{H}, J=4.4 \mathrm{~Hz}), 3.67-3.69(\mathrm{~m}, 2 \mathrm{H}), 3.62-$ $3.64(\mathrm{~m}, 2 \mathrm{H}), 2.45(\mathrm{~s}, 3 \mathrm{H}) .{ }^{13} \mathrm{C} \mathrm{NMR}\left(\mathrm{CDCl}_{3}, 100 \mathrm{MHz}\right): \delta 151.40$, $149.46,140.63,133.55,128.49,127.99,126.39,77.22,72.03,70.69$, 68.26, 67.15, 15.36. HRMS calcd for $\mathrm{C}_{15} \mathrm{H}_{18} \mathrm{~N}_{2} \mathrm{O}_{5} \mathrm{~S}[\mathrm{M}+\mathrm{H}]^{+}$ 339.1014 , found 339.1014.

[2-[(4-Methyl-5-thiazolyl)phenylmethoxy]ethoxy]ethanol (41). To a solution of $40(70 \mathrm{mg}, 0.21 \mathrm{mmol})$ in THF $(5 \mathrm{~mL})$ was added $\mathrm{LiAlH}_{4}(35 \mathrm{mg}, 0.85 \mathrm{mmol})$. The mixture was refluxed for $1 \mathrm{~h}$ and then quenched with methanol. Solvent was removed under reduced pressure, and the residue was diluted with ethyl acetate and washed with water. The crude product was purified by column chromatography $\left(\mathrm{SiO}_{2}\right.$, hexane/acetone, $\left.2: 1,25 \mathrm{mg}, 41 \%\right) .{ }^{1} \mathrm{H}$ NMR $\left(\mathrm{CDCl}_{3}, 400 \mathrm{MHz}\right): \delta 8.64(\mathrm{~s}, 1 \mathrm{H}), 7.29-7.38(\mathrm{~m}, 5 \mathrm{H}), 5.70(\mathrm{~s}, 1 \mathrm{H})$, $3.71-3.74(\mathrm{~m}, 4 \mathrm{H}), 3.60-3.66(\mathrm{~m}, 4 \mathrm{H}), 2.45(\mathrm{~s}, 3 \mathrm{H}) .{ }^{13} \mathrm{C} \mathrm{NMR}$ $\left(\mathrm{CDCl}_{3}, 100 \mathrm{MHz}\right): \delta 151.60,149.56,140.71,133.66,128.65,128.16$, 126.52, 72.38, 70.37, 68.49, 61.80, 15.52. HRMS calcd for $\mathrm{C}_{15} \mathrm{H}_{19} \mathrm{NO}_{3} \mathrm{~S}[\mathrm{M}+\mathrm{H}]^{+}$294.1164, found 294.1169.

$\mathrm{N}$-[(4-Methyl-5-thiazolyl)phenylmethyl]-[1-[(nitrooxy)methyl]cyclopropyl]methyl Carbamate (42). Compound 4 (160 $\mathrm{mg}, 0.78 \mathrm{mmol}$ ) and triphosgene $(297 \mathrm{mg}, 1.0 \mathrm{mmol})$ were dissolved in ethyl acetate $(10 \mathrm{~mL})$ and refluxed for $2 \mathrm{~h}$. Solvent was removed. The residue was redissolved in a mixture of THF $(5 \mathrm{~mL})$ and $\mathrm{NEt}_{3}$ $(0.25 \mathrm{~mL}, 1.8 \mathrm{mmol})$, and $34(147 \mathrm{mg}, 1 \mathrm{mmol})$ was added. The reaction mixture was stirred at $40{ }^{\circ} \mathrm{C}$ for $1 \mathrm{~h}$. Solvent was removed, and the product was purified by column chromatography $\left(\mathrm{SiO}_{2}\right.$, hexane/ethyl acetate, 2:1, $150 \mathrm{mg}, 51 \%) .{ }^{1} \mathrm{H} \mathrm{NMR}\left(\mathrm{CDCl}_{3}, 400\right.$ $\mathrm{MHz}): \delta 8.55(\mathrm{~s}, 1 \mathrm{H}), 7.27-7.36(\mathrm{~m}, 5 \mathrm{H}), 6.19(\mathrm{~s}, 1 \mathrm{H}), 5.98(\mathrm{~s}, 1 \mathrm{H})$, $4.35(\mathrm{~s}, 2 \mathrm{H}), 3.98(\mathrm{~s}, 2 \mathrm{H}), 2.39(\mathrm{~s}, 3 \mathrm{H}), 0.67-0.71(\mathrm{~m}, 4 \mathrm{H}) .{ }^{13} \mathrm{C}$ NMR $\left(\mathrm{CDCl}_{3}, 100 \mathrm{MHz}\right): \delta 155.21,150.51,149.68,140.32,133.53,128.69$, 
$127.93,126.39,77.06,68.31,51.97,30.68,18.33,15.08,9.41$. HRMS calcd for $\mathrm{C}_{17} \mathrm{H}_{19} \mathrm{~N}_{3} \mathrm{O}_{5} \mathrm{~S}[\mathrm{M}+\mathrm{H}]^{+} 378.1124$, found 378.1114 .

$\mathrm{N}$-[(4-Methyl-5-thiazolyl)phenylmethyl]-[4-(nitrooxy)butyl] Carbamate (43). Compound 43 was prepared from 4 and 4nitrooxybutan-1-ol ${ }^{90}$ using the same procedure described for $\mathbf{4 2}$. Product was purified by column chromatography $\left(\mathrm{SiO}_{2}\right.$, hexane/ethyl acetate, 2:1, 65\%). ${ }^{1} \mathrm{H}$ NMR $\left(\mathrm{CDCl}_{3}, 400 \mathrm{MHz}\right): \delta 8.60(\mathrm{~s}, 1 \mathrm{H})$, 7.27-7.38 (m, 5H), 6.19 (bs, $1 \mathrm{H}), 5.45$ (bs, $1 \mathrm{H}), 4.45$ (bs, $2 \mathrm{H}), 4.13$ $(\mathrm{t}, 2 \mathrm{H}, J=5.6 \mathrm{~Hz}), 2.41(\mathrm{~s}, 3 \mathrm{H}), 1.60-1.80(\mathrm{~m}, 4 \mathrm{H}) .{ }^{13} \mathrm{C}$ NMR $\left(\mathrm{CDCl}_{3}, 100 \mathrm{MHz}\right): \delta 155.35,150.46,149.51,140.31,133.60,128.60$, $127.83,126.35,72.40,64.10,51.81,25.01,23.18,14.98$. HRMS calcd for $\mathrm{C}_{16} \mathrm{H}_{19} \mathrm{~N}_{3} \mathrm{O}_{5} \mathrm{~S}[\mathrm{M}+\mathrm{H}]^{+} 366.1124$, found 366.1117.

$N$-[(4-Methyl-5-thiazolyl)phenylmethyl]-1-[(nitrooxy)methyl]cyclopropanecarboxamide (44). Compound 44 was prepared from 4 and 35 as described for 36 . The crude product was purified by column chromatography $\left(\mathrm{SiO}_{2}\right.$, hexane/ethyl acetate, 1:1, 49\%). ${ }^{1} \mathrm{H}$ NMR $\left(\mathrm{CDCl}_{3}, 300 \mathrm{MHz}\right): \delta 8.59(\mathrm{~s}, 1 \mathrm{H}), 7.23-7.38(\mathrm{~m}$, $5 \mathrm{H}), 6.61(\mathrm{~d}, 1 \mathrm{H}, J=7.2 \mathrm{~Hz}), 6.45(\mathrm{~d}, 1 \mathrm{H}, J=7.3 \mathrm{~Hz}), 4.58(\mathrm{~s}, 2 \mathrm{H})$, $2.39(\mathrm{~s}, 3 \mathrm{H}), 1.35-1.39(\mathrm{~m}, 2 \mathrm{H}), 0.94-0.97(\mathrm{~m}, 2 \mathrm{H}) .{ }^{13} \mathrm{C}$ NMR $\left(\mathrm{CDCl}_{3}, 100 \mathrm{MHz}\right): \delta 169.97,150.58,150.04,139.98,133.04,128.97$, $128.18,126.50,76.03,50.59,22.68,15.26,13.74,13.66$. HRMS calcd for $\mathrm{C}_{16} \mathrm{H}_{17} \mathrm{~N}_{3} \mathrm{O}_{4} \mathrm{~S}[\mathrm{M}+\mathrm{H}]^{+} 348.1018$, found 348.1008.

Stability of NO-Chimera in Neutral Phosphate Buffer. Stock solutions of 36,37 , and 42 were made in DMSO. 36 or $37(10 \mu \mathrm{M})$ and $5 \mathbf{i}$ (internal standard, $10 \mu \mathrm{M}$ ) were dissolved in phosphate buffer (100 mM, pH 7.4), and the final concentration of DMSO was $2 \%(\mathrm{v} /$ v). The solution was kept in the autosampler of the HPLC instrument at room temperature, and an aliquot $(50 \mu \mathrm{L})$ was injected into HPLC column. Injection occurred about every $7 \mathrm{~min}$ for 36 and $67 \mathrm{~min}$ for 37 because of the different stability of the two compounds. HPLC analysis was performed using a Shimadzu UFLC instrument with UV absorbance detection at $254 \mathrm{~nm}$. Separation of parent compound, hydrolysis product (compound 2), and internal standard (IS) was achieved using a Hypersil BDS C18 column $(2.1 \mathrm{~mm} \times 30 \mathrm{~mm}, 3$ $\mu \mathrm{m})$. The composition of the HPLC mobile phase was a mixture of water with $10 \%$ methanol, $0.1 \%$ formic acid (solution A), and acetonitrile with $0.1 \%$ formic acid (solution B). The mobile phase was initially composed of solvent A/solvent B (90:10), held for $1 \mathrm{~min}$, and then a linear gradient of solution B from $10 \%$ to $95 \%$ over the next 3 $\mathrm{min}$. The solvent was held at $95 \%$ of solution B over $1 \mathrm{~min}$, and the column was finally balanced using $10 \%$ solvent B for 1.5 min. Flow rate was $0.5 \mathrm{~mL} / \mathrm{min}$. Peak area ratio of parent compound vs internal standard was calculated at each time point and divided by the time zero value to give the percentage of compound remaining.

To detect the decomposition products of $\mathbf{4 2}$, the compound (100 $\mu \mathrm{M})$ was dissolved in phosphate buffer (100 mM, pH 7.4). The final concentration of DMSO was $2 \%(\mathrm{v} / \mathrm{v})$. The sample was placed in the dark at room temperature for $48 \mathrm{~h}$. An aliquot $(10 \mu \mathrm{L})$ of the sample was analyzed using an Agilent 6310 ion trap mass spectrometer (Agilent Technologies, Santa Clara, CA) equipped with Agilent 1100 HPLC system and electrospray ionization (ESI) source operated in positive mode. HPLC was performed using an Agilent Zorbax Bonus reverse phase C18 column $(3.0 \mathrm{~mm} \times 150 \mathrm{~mm}, 3.5 \mu \mathrm{m})$ with $\mathrm{UV}$ absorbance detection at $254 \mathrm{~nm}$. The composition of the HPLC mobile phase was a mixture of water with $10 \%$ methanol, $0.1 \%$ formic acid (solution A), and acetonitrile with $0.1 \%$ formic acid (solution B). The mobile phase was initially composed of solvent $\mathrm{A} /$ solvent $\mathrm{B}$ (90:10), held for $1 \mathrm{~min}$, and then a linear gradient of solution B from $10 \%$ to $80 \%$ over $17 \mathrm{~min}, 0.5 \mathrm{~min}$ gradient of solution B from $80 \%$ to $95 \%$ and held for $5 \mathrm{~min}$. Flow rate was set at $0.5 \mathrm{~mL} / \mathrm{min}$.

Animals. Male C57BL/ 6 mice aged $8-10$ weeks $(20-25$ g, Charles River Laboratories, IL) were used for step-through passive avoidance (STPA) task and brain bioavailability assay. Sprague-Dawley rat (gestational days 17-18, Charles River Laboratories, IL) were used for the primary neuronal cultures. Animals were housed at the BRL (biological resources laboratories) animal facility at the University of Illinois at Chicago (UIC). The animals were kept under standard laboratory conditions with free access to dry food and water but no nesting materials (Nestlets) supplied (not enriched environment). Regular light-dark cycle with at least $12 \mathrm{~h}$ of light was maintained throughout the housing in the facility. Animals were acclimated for at least 1 week in BRL before running any experiment. Also, $1-2 \mathrm{~h}$ prior to each testing, mice were habituated to the animal study room in the facility. All protocols using live animals were reviewed and approved by Institutional Animal Care and Use Committee (IACUC) at UIC (Animal Care Committee). Injection volumes were adjusted based on the animal weight $(0.1 \mathrm{~mL} / 25 \mathrm{~g}$ mouse $)$.

Double transgenic APP/PS1 mice expressing both the human APP (K670M:N671L) and PS1 (M146L) (line 6.2) mutations were used for the LTP study. They were obtained by crossing APP with PS1 animals. ${ }^{38}$ The animals were maintained on a $12 \mathrm{~h}$ light/dark cycle (with light onset at 6:00 a.m.) in temperature- and humidity-controlled rooms of the Columbia University Animal Facility. Food and water were available ad libitum.

Primary Neuronal Cultures. Primary cultures of rat cortical neurons were prepared as described. ${ }^{91}$ Briefly, brains were removed from embryonic day 17 Sprague-Dawley rat embryos, cortices were dissected, and meninges were removed. Neurons were mechanically dissociated in basal medium Eagle $1 \times$ containing glucose $(33 \mathrm{mM})$, glutamine $(2 \mathrm{mM}), 10 \%$ horse serum, and $10 \% \mathrm{FBS}$ and then plated at $3 \times 10^{5}$ cells $/ \mathrm{cm}^{2}$ in poly-L-lysine-precoated plates. The medium was replaced $24 \mathrm{~h}$ later with serum-free neurobasal medium (NBM) supplemented with $0.5 \mathrm{mmol} / \mathrm{L}$-glutamine and $2 \%$ complete B27 supplement. Four days later, $50 \%$ of the medium was replaced with fresh NBM. Neurons were used for OGD or NMDA cytotoxicity experiments after being grown for 8-10 days in NBM.

Primary Neurons Subject to Transient OGD Followed by Reoxygenation. Primary cortical cultured neurons were subjected to a transient OGD as described. ${ }^{92}$ On days $8-10$ of culture, cultured neurons were placed in a humidified $37{ }^{\circ} \mathrm{C}$ incubator $\left(95 \% \mathrm{~N}_{2}, 5 \%\right.$ $\mathrm{CO}_{2}$ ) and the culture medium was replaced with deoxygenated, glucose-free balanced salt solution, $\mathrm{pH} 7.4$, containing the following (in $\mathrm{mM}$ ): $\mathrm{NaCl} 116, \mathrm{CaCl}_{2} 1.8, \mathrm{MgSO}_{4} 0.8, \mathrm{KCl} 5.4, \mathrm{NaH}_{2} \mathrm{PO}_{4} 1$, $\mathrm{NaHCO}_{3}$ 14.7, and HEPES 10. Following $2 \mathrm{~h}$ of OGD incubation, OGD was ended by replacing OGD medium with testing compound conditioned fresh NBM (supplemented with $0.5 \mathrm{mmol} / \mathrm{L}$-glutamine and B27 without antioxidants). Cultures were returned to the normoxic $37{ }^{\circ} \mathrm{C}$ incubator $\left(5 \% \mathrm{CO}_{2}\right)$ for $24 \mathrm{~h}$ prior to evaluation of cell viability and neuronal death by MTT and LDH assays. The test compounds $(50 \mu \mathrm{M})$ were present during the $2 \mathrm{~h}$ OGD and $24 \mathrm{~h}$ reoxygenation.

NMDA and Glutamate Induced Cytotoxicity in Primary Neurons. Primary cortical cultured neurons were subjected to NMDA induced cytotoxicity as described. ${ }^{93,94}$ On day 11 of culture, primary neurons were preincubated with testing compounds $(50 \mu \mathrm{M})$ for 30 min in neurobasal culture mudium and were exposed to NMDA (100 $\mu \mathrm{M}$ ) in HEPES-buffered salt solution containing the following (in $\mathrm{mM}$ ): $\mathrm{NaCl} 20, \mathrm{KCl} 5.4, \mathrm{MgCl}_{2} 0.8, \mathrm{CaCl}_{2} 1.8$, glucose 15, and HEPES 20 ( $\mathrm{pH} 7.4)$. Twenty-four hours later, cell viability and neuronal death were evaluated by MTT and LDH assays. The testing compounds $(50 \mu \mathrm{M})$ were presented during the preincubation and 24 $\mathrm{h}$ chronic NMDA cytotoxicity. MTT assay for cell viability and LDH assay of cell death were performed as described previously. ${ }^{95}$

To probe the mechanism of neuroprotection elicited by MZ derivatives, after 10-11 DIV (days in vitro), picrotoxin $(100 \mu \mathrm{M})$ was added to primary neuronal cultures $1 \mathrm{~h}$ before glutamate $(100 \mu \mathrm{M})$ insult. One hour after glutamate addition, $\mathrm{MZ}$ derivatives or muscimol were supplied at a final concentration of $50 \mu \mathrm{M}$. After incubation for $24 \mathrm{~h}$, final cell survival was assayed using MTT. For comparison, picrotoxin treatment was omitted in another experiment.

LTP Measurement. Hippocampal slice preparation was performed as described. ${ }^{38}$ Briefly, APP/PS1 trangenic mice were decapitated and their hippocampi were quickly removed. Transverse hippocampal slices $(400 \mu \mathrm{m})$ were cut and transferred to an interface chamber, where they were maintained at $29^{\circ} \mathrm{C}$. They were perfused $(1-3 \mathrm{~mL} /$ min) with saline solution $(124.0 \mathrm{mM} \mathrm{NaCl} / 4.4 \mathrm{mM} \mathrm{KCl} / 1.0 \mathrm{mM}$ $\mathrm{Na}_{2} \mathrm{HPO}_{4} / 25.0 \mathrm{mM} \mathrm{NaHCO} / 2.0 \mathrm{mM} \mathrm{CaCl} / 2.0 \mathrm{mM} \mathrm{MgSO} / 10$ $\mathrm{mM}$ glucose) continuously bubbled with $95 \% \mathrm{O}_{2}$ and $5 \% \mathrm{CO}_{2}$. Slices were maintained at $29{ }^{\circ} \mathrm{C}$ for $90 \mathrm{~min}$ before recording. The CA1 region of the hippocampus field excitatory postsynaptic potentials 
(fEPSPs) were recorded by placing both the stimulating and the recording electrodes in CA1 stratum radiatum. A 15 min baseline was recorded every minute at an intensity that evokes a response of approximately $35 \%$ of the maximum evoked response. LTP was induced using $\theta$-burst stimulation at $20 \mathrm{~min}$. Responses were recorded for $1 \mathrm{~h}$ after tetanization.

Step-Through Passive Avoidance (STPA) Task. The STPA apparatus consists of a two-compartment acrylic box with an illuminated side $(15 \mathrm{~cm} \times 12 \mathrm{~cm} \times 12 \mathrm{~cm})$ connected to a dark side $(15 \mathrm{~cm} \times 12 \mathrm{~cm} \times 12 \mathrm{~cm})$ by a vertical door. The dark side is equipped with an electric grid floor. Animals was habituated to translocating to the dark from the light side until latency of entering the dark side for each animal is $<30 \mathrm{~s}$. During training, animals received an aversive electrical shock $(0.5 \mathrm{~mA}, 2 \mathrm{~s})$, triggered by entry to the dark compartment, until the latency of entering the dark side reaches $300 \mathrm{~s}$. To test procognitive activity of NO-chimeras, scopolamine $(1.0 \mathrm{mg} / \mathrm{kg}$, ip) was given $30 \mathrm{~min}$ before training and drug $(4.5 \mu \mathrm{mol} / \mathrm{kg}$, ip) was administered $20 \mathrm{~min}$ before training. At 24 $\mathrm{h}$ after training, the animals were again individually placed in the light compartment and the latency to enter the dark comparment, without shock stimulus, was recorded. Statistical analysis of the latency data was performed with one-way ANOVA followed by Bonferroni multiple comparison test.

Brain Bioavailability of NO-Chimeras. Mice were injected (ip) with drug at a dosage that was equimolar with $1(4.5 \mu \mathrm{mol} / \mathrm{kg}$, ip). Four mice were used for the injection of each drug. Brain tissues were collected $20 \mathrm{~min}$ after ip injection. Analytes were extracted as follows: to a mixture of blank brain tissue $(100 \mathrm{mg})$ and cold acetonitrile/ $\mathrm{MeOH}(1: 1,600 \mu \mathrm{L})$, internal standard $(400 \mathrm{ng} / \mathrm{mL}, 10 \mu \mathrm{L})$ in acetonitrile $/ \mathrm{MeOH}(1: 1)$ was added. Brain tissue was homogenized manually using a disposable pestle, vortexed, and then centrifuged at 4 ${ }^{\circ} \mathrm{C}, 13000 \mathrm{rpm}$ for $15 \mathrm{~min}$. The supernatant was transferred to another vial. The remaining pellet was washed and extracted with cold acetonitrile/ $\mathrm{MeOH}(300 \mu \mathrm{L}, 1: 1 \mathrm{v} / \mathrm{v})$ and centrifuged as described above. Supernatants were combined and stored at $-20{ }^{\circ} \mathrm{C}$ for $1 \mathrm{~h}$, allowing further protein precipitation. The clear supernatant from centrifugation was collected and concentrated using a flow of $\mathrm{N}_{2}$. The residue was reconstituted with solvent $\left(200 \mu \mathrm{L}, \mathrm{H}_{2} \mathrm{O} / \mathrm{MeOH} /\right.$ acetonitrile, 50/25/25, v/v), vortexed, centrifuged, and analyzed using LC-MS/MS. To construct standard curves, working solutions in $\mathrm{MeOH} /$ acetonitrile $/ \mathrm{H}_{2} \mathrm{O}$ (0.5:0.5:1) containing NO-chimera and corresponding hydroxyl compound at different concentrations were prepared. Concentrations of working solutions were 2000, 1000, 500, $200,80,40,20 \mathrm{ng} / \mathrm{mL}$. To a mixture of blank brain tissue $(100 \mathrm{mg})$ and cold acetonitrile/MeOH $(1: 1,600 \mu \mathrm{L})$ were added each analyte working solution $(10 \mu \mathrm{L})$ and internal standard $(400 \mathrm{ng} / \mathrm{mL}, 10 \mu \mathrm{L})$. Calibration samples were extracted as described above, and the final concentrations of analytes after reconstitution were 100, 50, 25, 10, 4, $2,1 \mathrm{ng} / \mathrm{mL}$. The final concentration of IS was $20 \mathrm{ng} / \mathrm{mL}$.

All LC-MS/MS measurements were carried out using the positive mode electrospray ionization method on an API 3000 (Applied Biosystem, Foster City, CA) triple quadrupole mass spectrometer attached to an Agilent 1200 HPLC (Agilent Technologies) instrument. MRM transitions for the detection of analytes and internal standards are described in Table 2. HPLC was performed with a Waters XBridge $\mathrm{C} 18$ column $(3.5 \mu \mathrm{m}, 3 \mathrm{~mm} \times 100 \mathrm{~mm})$. Flow rate was set at $0.35 \mathrm{~mL} / \mathrm{min}$. The composition of the HPLC mobile phase was a mixture of water with $10 \%$ methanol, $0.1 \%$ formic acid (solution A), and acetonitrile with $0.1 \%$ formic acid (solution B). To analyze 32a and 22a, the mobile phase was initially composed of solvent $A$ / solvent B (90:10), held for $1 \mathrm{~min}$, and a linear gradient of solution B from $10 \%$ to $60 \%$ over the next $1 \mathrm{~min}$. The composition of $\mathrm{B}$ was then increased to $99 \%$ in $13 \mathrm{~min}$. The solvent was held at $99 \%$ of solution B over $5 \mathrm{~min}$, and the column was finally balanced using $10 \%$ solvent B for $5 \mathrm{~min}$. To analyze 26 and 28 , the mobile phase was initially composed of solvent A/solvent B (95:5), held for $1 \mathrm{~min}$, and a linear gradient of solution B from $10 \%$ to $60 \%$ over next 1 min. Composition of B was then increased to $99 \%$ in $11 \mathrm{~min}$. The solvent was held at $99 \%$ of solution B over $5 \mathrm{~min}$, and the column was finally balanced using $5 \%$ solvent B for 5 min.
Statistical Analyses. For all experiments, data were expressed as the mean \pm SEM. LTP results were analyzed with two-way ANOVA. STPA results were analyzed with one-way ANOVA followed by Bonferroni multiple comparison test. The level of significance was set for $p<0.05$.

\section{ASSOCIATED CONTENT}

\section{Supporting Information}

HPLC chromatogram of the incubation of $\mathbf{4 2}$ in phosphate buffer $(100 \mathrm{mM}, \mathrm{pH} 7.4)$ at room temperature for $48 \mathrm{~h}$ and the proposed mechanism of decomposition (Figure S1); inhibition of excitotoxic cell death from treatment with NMDA $(100 \mu \mathrm{M})$ by CMZ and by a number of MZ derivatives (Table S1). This material is available free of charge via the Internet at http:// pubs.acs.org.

\section{AUTHOR INFORMATION}

\section{Corresponding Author}

*Phone: 312-355-5282. Fax: 312-996-7107. E-mail: thatcher@ uic.edu.

\section{Notes}

The authors declare the following competing financial interest(s): G.R.J.T. has a consulting relationship with sGC Pharma, an entity that currently licenses intellectual property associated with nomethiazoles from the University of Illinois.

\section{ACKNOWLEDGMENTS}

The work was supported by NIH Grant U01 AG031294. Hong Zhang and Ian J. Orozco are thanked for technical assistance.

\section{ABBREVIATIONS USED}

NO-GC, NO-sensitive or soluble guanylyl cyclase; cGK, cGMP-dependent protein kinase; CREB, cyclic adenosine 5'monophosphate response element binding protein; LTP, longterm potentiation; $\mathrm{A} \beta$, amyloid $\beta ; \mathrm{AD}$, Alzheimer's disease; BDNF, brain derived neurotropic growth factor; MAPK, mitogen activated protein kinase; ESI, electrospray ionization; MTT, 3-(4,5-dimethylthiazol-2-yl)-2,5-diphenyltetrazolium bromide; MZ, 4-methylthiazole; NMDA, $N$-methyl-D-aspartate; OGD, oxygen glucose deprivation; DIV, day in vitro; $\mathrm{NO}_{x}$, a nitrogen oxide (including $\mathrm{NO}, \mathrm{NO}_{2}{ }^{-}$, and $\mathrm{NO}_{3}{ }^{-}$); STPA, stepthrough passive avoidance; MRM, multiple reaction monitoring

\section{REFERENCES}

(1) Wimo, A.; Winblad, B.; Jonsson, L. The worldwide societal costs of dementia: estimates for 2009. Alzheimer's Dement 2010, 6, 98-103.

(2) Cummings, J. L. Alzheimer's disease. N. Engl. J. Med. 2004, 351, 56-67.

(3) Selkoe, D. J. Resolving controversies on the path to Alzheimer's therapeutics. Nat. Med. 2011, 17, 1060-1065.

(4) Mangialasche, F.; Solomon, A.; Winblad, B.; Mecocci, P.; Kivipelto, M. Alzheimer's disease: clinical trials and drug development. Lancet Neurol. 2010, 9, 702-716.

(5) Citron, M. Alzheimer's disease: strategies for disease modification. Nat. Rev. Drug Discovery 2010, 9, 387-398.

(6) Nelson, R. M.; Hainsworth, A. H.; Lambert, D. G.; Jones, J. A.; Murray, T. K.; Richards, D. A.; Gabrielsson, J.; Cross, A. J.; Green, A. R. Neuroprotective efficacy of AR-A008055, a clomethiazole analogue, in a global model of acute ischaemic stroke and its effect on ischaemiainduced glutamate and GABA efflux in vitro. Neuropharmacology 2001, 41, 159-166.

(7) Green, A. R.; Hainsworth, A. H.; Misra, A.; Debens, T. A.; Jackson, D. M.; Murray, T. K.; Nelson, R. M.; Cross, A. J. The interaction of AR-A008055 and its enantiomers with the GABA(A) 
receptor complex and their sedative, muscle relaxant and anticonvulsant activity. Neuropharmacology 2001, 41, 167-174.

(8) Colado, M. I.; O'Shea, E.; Esteban, B.; Green, A. R. Studies on the neuroprotective effect of the enantiomers of AR-A008055, a compound structurally related to clomethiazole, on MDMA ("ecstasy")-induced neurodegeneration in rat brain. Psychopharmacology 2001, 157, 82-88.

(9) Lechat, P.; Streichenberger, G.; Boime, A.; Lemeignan, M. Relation between chemical structure and physiological activity of certain thiazole derivatives. I. 4-Methyl-5-( $\beta$-hydroxyethyl)thiazole. Ann. Pharm. Fr. 1965, 23, 179-186.

(10) Lechat, P.; Streichenberger, G.; Boime, A.; Lemeignan, M. Relations between the chemical structure and physiological activity of certain thiazole derivatives. II. Effect of the length of the alkyl chain in 4-methyl-5-( $\omega$-chloroalkyl)thiazoles. Ann. Pharm. Fr. 1965, 23, 369576.

(11) Lechat, P.; van den Driessche, J.; Lemeignan, M.; Deleau, D. Pharmacological investigation of a quaternary ammonium compound with ganglion-exciting properties. Arch. Int. Pharmacodyn. Ther. 1965, 155, 262-272.

(12) Bengtsson, S.; Lindberg, U. H. Compounds related to clomethiazole. VI. Synthesis of some reference compounds in connection with biotransformation studies. Acta Pharm. Suec. 1982, $19,37-42$.

(13) Lindberg, U. H. Compounds related to clomethiazole. I. Oxazole and pyridine isosteres of clomethiazole. Acta Pharm. Suec. 1966, 3, 161-166.

(14) Lindberg, U. H.; Pedersen, J.; Ulff, B. Compounds related to clomethiazole. II. Haloalkyl and aminoalkyl analogs of clomethiazole. Acta Pharm. Suec. 1967, 4, 269-280.

(15) Lindberg, U. H. Hypnotic and anticonvulsant agents related to the thiazole part of thiamine. Acta Pharm. Suec. 1971, 8, 647-660.

(16) Lindberg, U. H. Compounds related to clomethiazole. IV. 4Methylthiazoles and oxazoles with polar side-chains and some other analogs of clomethiazole. Acta Pharm. Suec. 1971, 8, 39-48.

(17) Lindberg, U. H.; Bexell, G.; Ulff, B. Compounds related to clomethiazole. V. 4-(Alkyl or aryl) thiazoles and oxazoles with various substituents in the 2- and 5-positions. Acta Pharm. Suec. 1971, 8, 4958.

(18) Green, A. R. Clomethiazole (Zendra) in acute ischemic stroke: basic pharmacology and biochemistry and clinical efficacy. Pharmacol. Ther. 1998, 80, 123-147.

(19) Marshall, J. W.; Cross, A. J.; Ridley, R. M. Functional benefit from clomethiazole treatment after focal cerebral ischemia in a nonhuman primate species. Exp. Neurol. 1999, 156, 121-129.

(20) Farooque, M.; Isaksson, J.; Jackson, D. M.; Olsson, Y. Clomethiazole (ZENDRA, CMZ) improves hind limb motor function and reduces neuronal damage after severe spinal cord injury in rat. Acta Neuropathol. 1999, 98, 22-30.

(21) Wahlgren, N. G.; Diez-Tejedor, E.; Teitelbaum, J.; Arboix, A.; Leys, D.; Ashwood, T.; Grossman, E. Results in 95 hemorrhagic stroke patients included in CLASS, a controlled trial of clomethiazole versus placebo in acute stroke patients. Stroke 2000, 31, 82-85.

(22) Wahlgren, N. G.; Ranasinha, K. W.; Rosolacci, T.; Franke, C. L.; van Erven, P. M.; Ashwood, T.; Claesson, L. Clomethiazole acute stroke study (CLASS): results of a randomized, controlled trial of clomethiazole versus placebo in 1360 acute stroke patients. Stroke 1999, 30, 21-28.

(23) Mucke, H. Clomethiazole (Astra Arcus AB). IDrugs 1999, 2, 184-193.

(24) Lyden, P.; Jacoby, M.; Schim, J.; Albers, G.; Mazzeo, P.; Ashwood, T.; Nordlund, A.; Odergren, T. The clomethiazole acute stroke study in tissue-type plasminogen activator-treated stroke (CLASS-T): final results. Neurology 2001, 57, 1199-1205.

(25) Lyden, P.; Shuaib, A.; Ng, K.; Levin, K.; Atkinson, R. P.; Rajput, A.; Wechsler, L.; Ashwood, T.; Claesson, L.; Odergren, T.; SalazarGrueso, E. Clomethiazole acute stroke study in ischemic stroke (CLASS-I): final results. Stroke 2002, 33, 122-128.
(26) Wilby, M. J.; Hutchinson, P. J. The pharmacology of chlormethiazole: a potential neuroprotective agent? CNS Drug Rev. 2004, 10, 281-294.

(27) Harmon, D.; Coleman, E.; Marshall, C.; Lan, W.; Shorten, G. The effect of clomethiazole on plasma concentrations of interleukin-6, $-8,-1$ beta, tumor necrosis factor-alpha, and neutrophil adhesion molecule expression during experimental extracorporeal circulation. Anesth. Analg. 2003, 97, 13-18.

(28) Clarkson, A. N.; Liu, H.; Rahman, R.; Jackson, D. M.; Appleton, I.; Kerr, D. S. Clomethiazole: mechanisms underlying lasting neuroprotection following hypoxia-ischemia. FASEB J. 2005, 19, $1036-1038$

(29) Clarkson, A. N.; Clarkson, J.; Jackson, D. M.; Sammut, I. A. Mitochondrial involvement in transhemispheric diaschisis following hypoxia-ischemia: clomethiazole-mediated amelioration. Neuroscience 2007, 144, 547-561.

(30) Shi, J. Q.; Shen, W.; Chen, J.; Wang, B. R.; Zhong, L. L.; Zhu, Y. W.; Zhu, H. Q.; Zhang, Q. Q.; Zhang, Y. D.; Xu, J. Anti-TNF-alpha reduces amyloid plaques and tau phosphorylation and induces CD11cpositive dendritic-like cell in the APP/PS1 transgenic mouse brains. Brain Res. 2011, 1368, 239-247.

(31) Alvarez, A.; Cacabelos, R.; Sanpedro, C.; Garcia-Fantini, M.; Aleixandre, M. Serum TNF-alpha levels are increased and correlate negatively with free IGF-I in Alzheimer disease. Neurobiol. Aging 2007, $28,533-536$.

(32) McAlpine, F. E.; Lee, J. K.; Harms, A. S.; Ruhn, K. A.; BlurtonJones, M.; Hong, J.; Das, P.; Golde, T. E.; LaFerla, F. M.; Oddo, S.; Blesch, A.; Tansey, M. G. Inhibition of soluble TNF signaling in a mouse model of Alzheimer's disease prevents pre-plaque amyloidassociated neuropathology. Neurobiol. Dis. 2009, 34, 163-177.

(33) Strum, J. C.; Shehee, R.; Virley, D.; Richardson, J.; Mattie, M.; Selley, P.; Ghosh, S.; Nock, C.; Saunders, A.; Roses, A. Rosiglitazone induces mitochondrial biogenesis in mouse brain. J. Alzheimer's Dis. 2007, 11, 45-51

(34) Santos, R. X.; Correia, S. C.; Carvalho, C.; Cardoso, S.; Santos, M. S.; Moreira, P. I. Mitophagy in neurodegeneration: an opportunity for therapy? Curr. Drug Targets 2011, 12, 790-799.

(35) Selkoe, D. J. Alzheimer's disease is a synaptic failure. Science 2002, 298, 789-91.

(36) Thatcher, G. R. J.; Bennett, B. M.; Reynolds, J. N. NO chimeras as therapeutic agents in Alzheimer's disease. Curr. Alzheimer Res. 2006, $3,237-245$.

(37) Bennett, B. M.; Reynolds, J. N.; Prusky, G. T.; Douglas, R. M.; Sutherland, R. J.; Thatcher, G. R. J. Cognitive deficits in rats after forebrain cholinergic depletion are reversed by a novel NO mimetic nitrate ester. Neuropsychopharmacology 2007, 32, 505-513.

(38) Puzzo, D.; Staniszewski, A.; Deng, S. X.; Privitera, L.; Leznik, E.; Liu, S.; Zhang, H.; Feng, Y.; Palmeri, A.; Landry, D. W.; Arancio, O. Phosphodiesterase 5 inhibition improves synaptic function, memory, and amyloid-beta load in an Alzheimer's disease mouse model. $J$. Neurosci. 2009, 29, 8075-8086.

(39) Saura, C. A.; Valero, J. The role of CREB signaling in Alzheimer's disease and other cognitive disorders. Rev. Neurosci. 2011, $22,153-169$.

(40) Espana, J.; Valero, J.; Minano-Molina, A. J.; Masgrau, R.; Martin, E.; Guardia-Laguarta, C.; Lleo, A.; Gimenez-Llort, L.; RodriguezAlvarez, J.; Saura, C. A. beta-Amyloid disrupts activity-dependent gene transcription required for memory through the CREB coactivator CRTC1. J. Neurosci. 2010, 30, 9402-9410.

(41) Wang, A.; Bibb, J. A. Is CREB the angry bird that releases memory in alzheimer's? Neuropsychopharmacology 2011, 36, 21532154.

(42) Pugazhenthi, S.; Wang, M.; Pham, S.; Sze, C. I.; Eckman, C. B. Downregulation of CREB expression in Alzheimer's brain and in Abeta-treated rat hippocampal neurons. Mol. Neurodegener. 2011, 6, 60.

(43) Yiu, A. P.; Rashid, A. J.; Josselyn, S. A. Increasing CREB function in the CA1 region of dorsal hippocampus rescues the spatial 
memory deficits in a mouse model of Alzheimer's disease. Neuropsychopharmacology 2011, 36, 2169-2186.

(44) Lu, Y. F.; Kandel, E. R.; Hawkins, R. D. Nitric oxide signaling contributes to late-phase LTP and CREB phosphorylation in the hippocampus. J. Neurosci. 1999, 19, 10250-10261.

(45) Riccio, A.; Alvania, R. S.; Lonze, B. E.; Ramanan, N.; Kim, T.; Huang, Y.; Dawson, T. M.; Snyder, S. H.; Ginty, D. D. A nitric oxide signaling pathway controls CREB-mediated gene expression in neurons. Mol. Cell 2006, 21, 283-294.

(46) Zhuo, M.; Hu, Y.; Schultz, C.; Kandel, E. R.; Hawkins, R. D. Role of guanylyl cyclase and cGMP-dependent protein kinase in longterm potentiation. Nature 1994, 368, 635-639.

(47) Puzzo, D.; Vitolo, O.; Trinchese, F.; Jacob, J. P.; Palmeri, A.; Arancio, O. Amyloid-beta peptide inhibits activation of the nitric oxide/cGMP/cAMP-responsive element-binding protein pathway during hippocampal synaptic plasticity. J. Neurosci. 2005, 25, 68876897.

(48) Puzzo, D.; Palmeri, A.; Arancio, O. Involvement of the nitric oxide pathway in synaptic dysfunction following amyloid elevation in Alzheimer's disease. Rev. Neurosci. 2006, 17, 497-523.

(49) Paul, C.; Stratil, C.; Hofmann, F.; Kleppisch, T. cGMPdependent protein kinase type I promotes CREB/CRE-mediated gene expression in neurons of the lateral amygdala. Neurosci. Lett. 2010, 473, $82-86$.

(50) Thatcher, G. R. J.; Bennett, B. M.; Reynolds, J. N. Nitric oxide mimetic molecules as therapeutic agents in Alzheimer's disease. Curr. Alzheimer Res. 2005, 2, 171-182.

(51) Rostovtsev, V. V.; Green, L. G.; Fokin, V. V.; Sharpless, K. B. A stepwise Huisgen cycloaddition process: copper(I)-catalyzed regioselective "ligation" of azides and terminal alkynes. Angew. Chem., Int. Ed. 2002, 41, 2596-2599.

(52) Tornoe, C. W.; Christensen, C.; Meldal, M. Peptidotriazoles on solid phase: [1,2,3]-triazoles by regiospecific copper(I)-catalyzed 1,3dipolar cycloadditions of terminal alkynes to azides. J. Org. Chem. 2002, 67, 3057-3064.

(53) Moorhouse, A. D.; Moses, J. E. Click chemistry and medicinal chemistry: a case of "cyclo-addiction". ChemMedChem 2008, 3, 715723.

(54) Jones, R. W. Dimebon disappointment. Alzheimer's Res. Ther. 2010, 2, 25.

(55) Lizarzaburu, M. E.; Shuttleworth, S. J. 1,2,3,4-Tetrahydro-ccarbolinium salts: novel reactions with thiols, mediated by polymersupported reagents. Tetrahedron Lett. 2004, 45, 4781-4783.

(56) Charonnat, R.; Lechat, P.; Chareton, J. From a convulsive to an anticonvulsive product in the thiamine series. Therapie 1956, 11, 261264.

(57) Ogren, S. O. Chlormethiazole-mode of action. Acta Psychiatr. Scand., Suppl. 1986, 329, 13-27.

(58) Hedlund, B.; Ogren, S. O. Chlormethiazole acts on chloride channels in cultured spinal cord neurons. Neurosci. Lett. 1987, 78, 217-221.

(59) Nelson, R. M.; Green, A. R.; Hainsworth, A. H. Electrophysiological actions of $\gamma$-aminobutyric acid and clomethiazole on recombinant GABAA receptors. Eur. J. Pharmacol. 2002, 452, 255262.

(60) Marshall, J. W.; Cross, A. J.; Jackson, D. M.; Green, A. R.; Baker, H. F.; Ridley, R. M. Clomethiazole protects against hemineglect in a primate model of stroke. Brain Res. Bull. 2000, 52, 21-29.

(61) Gilby, K. L.; Sydserff, S. G.; Robertson, H. A. Differential neuroprotective effects for three GABA-potentiating compounds in a model of hypoxia-ischemia. Brain Res. 2005, 1035, 196-205.

(62) Wang, Q.; Walsh, D. M.; Rowan, M. J.; Selkoe, D. J.; Anwyl, R. Block of long-term potentiation by naturally secreted and synthetic amyloid beta-peptide in hippocampal slices is mediated via activation of the kinases c-Jun N-terminal kinase, cyclin-dependent kinase 5, and p38 mitogen-activated protein kinase as well as metabotropic glutamate receptor type 5. J. Neurosci. 2004, 24, 3370-3378.
(63) Rowan, M. J.; Klyubin, I.; Wang, Q.; Anwyl, R. Mechanisms of the inhibitory effects of amyloid beta-protein on synaptic plasticity. Exp. Gerontol. 2004, 39, 1661-1667.

(64) Green, A. R.; Murray, T. K.; Misra, A.; Snape, M. F.; Jones, J. A.; Cross, A. J. The metabolism of clomethiazole in gerbils and the neuroprotective and sedative activity of the metabolites. Br. J. Pharmacol. 2000, 129, 95-100.

(65) Ende, M.; Spiteller, G.; Remberg, G.; Heipertz, R. Urinary metabolites of clomethiazole. Detection and structural analysis by gas chromatography-mass spectrometry. Arzneim. Forsch. 1979, 29, 1655-8.

(66) Simi, A.; Ingelman-Sundberg, M.; Tindberg, N. Neuroprotective agent chlomethiazole attenuates c-fos, c-jun, and AP-1 activation through inhibition of p38 MAP kinase. J. Cereb. Blood Flow Metab 2000, 20, 1077-1088.

(67) Impey, S.; Goodman, R. H. CREB signaling-timing is everything. Sci. STKE 2001, 2001, PE1.

(68) Radley, E.; Akram, A.; Grubb, B. D.; Gibson, C. L. Investigation of the mechanisms of progesterone protection following oxygenglucose deprivation in organotypic hippocampal slice cultures. Neurosci. Lett. 2012, 506, 131-135.

(69) Whalley, B. J.; Stephens, G. J.; Constanti, A. Investigation of the effects of the novel anticonvulsant compound carisbamate (RWJ333369) on rat piriform cortical neurones in vitro. Br. J. Pharmacol. 2009, 156, 994-1008.

(70) Pond, B. B.; Berglund, K.; Kuner, T.; Feng, G.; Augustine, G. J.; Schwartz-Bloom, R. D. The chloride transporter $\mathrm{Na}(+)-\mathrm{K}(+)-\mathrm{Cl}-$ cotransporter isoform- 1 contributes to intracellular chloride increases after in vitro ischemia. J. Neurosci. 2006, 26, 1396-406.

(71) Gravielle, M. C.; Faris, R.; Russek, S. J.; Farb, D. H. GABA induces activity dependent delayed-onset uncoupling of GABA/ benzodiazepine site interactions in neocortical neurons. J. Biol. Chem. 2005, 280, 20954-60.

(72) Sedelnikova, A.; Erkkila, B. E.; Harris, H.; Zakharkin, S. O.; Weiss, D. S. Stoichiometry of a pore mutation that abolishes picrotoxin-mediated antagonism of the GABAA receptor. J. Physiol. 2006, 577, 569-577.

(73) Korshoej, A. R.; Holm, M. M.; Jensen, K.; Lambert, J. D. Kinetic analysis of evoked IPSCs discloses mechanism of antagonism of synaptic GABAA receptors by picrotoxin. Br. J. Pharmacol. 2010, 159, 636-649.

(74) Sceniak, M. P.; Maciver, M. B. Slow GABA(A) mediated synaptic transmission in rat visual cortex. BMC Neurosci. 2008, 9, 8.

(75) Han, S. M.; Youn, D. H. GABAA receptor-mediated tonic currents in substantia gelatinosa neurons of rat spinal trigeminal nucleus pars caudalis. Neurosci. Lett. 2008, 441, 296-301.

(76) Fletcher, J. T.; Walz, S. E.; Keeney, M. E. Monosubstituted 1,2,3-triazoles from two-step one-pot deprotection/click additions of trimethylsilylacetylene. Tetrahedron Lett. 2008, 49, 7030-7032.

(77) Bender, D. M.; Peterson, J. A.; McCarthy, J. R.; Gunaydin, H.; Takano, Y.; Houk, K. N. Cyclopropanecarboxylic acid esters as potential prodrugs with enhanced hydrolytic stability. Org. Lett. 2008, 10, 509-511.

(78) Buckell, F.; Hartry, J. D.; Rajalingam, U.; Bennett, B. M.; Whitney, R. A.; Thatcher, G. R. J. Hydrolysis of nitrite esters: putative intermediates in the biotransformation of organic nitrates. J. Chem. Soc., Perkin Trans. 2 1994, 401-403.

(79) Sant'Angelo, A.; Trinchese, F.; Arancio, O. Usefulness of behavioral and electrophysiological studies in transgenic models of Alzheimer's disease. Neurochem. Res. 2003, 28, 1009-1015.

(80) Bliss, T. V.; Collingridge, G. L. A synaptic model of memory: long-term potentiation in the hippocampus. Nature 1993, 361, 31-39.

(81) Trinchese, F.; Liu, S.; Battaglia, F.; Walter, S.; Mathews, P. M.; Arancio, O. Progressive age-related development of Alzheimer-like pathology in APP/PS1 mice. Ann. Neurol. 2004, 55, 801-814.

(82) Gong, B.; Vitolo, O. V.; Trinchese, F.; Liu, S.; Shelanski, M.; Arancio, O. Persistent improvement in synaptic and cognitive functions in an Alzheimer mouse model after rolipram treatment. $J$. Clin. Invest. 2004, 114, 1624-1634. 
(83) Schindler, U. Pre-clinical evaluation of cognition enhancing drugs. Prog. Neuro-Psychopharmacol. Biol. Psychiatry 1989, 13 (Suppl.), S99-S115.

(84) Abdul-Hay, S.; Schiefer, I. T.; Chandrasena, R. E.; Li, M.; Abdelhamid, R.; Wang, Y. T.; Tavassoli, E.; Michalsen, B.; Asghodom, R. T.; Luo, J.; Thatcher, G. R. NO-SSRIs: nitric oxide chimera drugs incorporating a selective serotonin reuptake inhibitor. ACS Med. Chem. Lett. 2011, 2, 656-661.

(85) Satoh, J.; Tabunoki, H.; Arima, K. Molecular network analysis suggests aberrant CREB-mediated gene regulation in the Alzheimer disease hippocampus. Dis. Markers 2009, 27, 239-252.

(86) Louzada, P. R.; Paula Lima, A. C.; Mendonca-Silva, D. L.; Noel, F.; De Mello, F. G.; Ferreira, S. T. Taurine prevents the neurotoxicity of beta-amyloid and glutamate receptor agonists: activation of GABA receptors and possible implications for Alzheimer's disease and other neurological disorders. FASEB J. 2004, 18, 511-518.

(87) Lin, X.; Jun-Tian, Z. Neuroprotection by D-securinine against neurotoxicity induced by beta-amyloid (25-35). Neurol. Res. 2004, 26, 792-796.

(88) Lee, B. Y.; Ban, J. Y.; Seong, Y. H. Chronic stimulation of GABAA receptor with muscimol reduces amyloid beta protein (2535 )-induced neurotoxicity in cultured rat cortical cells. Neurosci. Res. 2005, 52, 347-356.

(89) Marcade, M.; Bourdin, J.; Loiseau, N.; Peillon, H.; Rayer, A.; Drouin, D.; Schweighoffer, F.; Desire, L. Etazolate, a neuroprotective drug linking $\mathrm{GABA}(\mathrm{A})$ receptor pharmacology to amyloid precursor protein processing. J. Neurochem. 2008, 106, 392-404.

(90) Ziakas, G. N.; Rekka, E. A.; Gavalas, A. M.; Eleftheriou, P. T.; Tsiakitzis, K. C.; Kourounakis, P. N. Nitric oxide releasing derivatives of tolfenamic acid with anti-inflammatory activity and safe gastrointestinal profile. Bioorg. Med. Chem. 2005, 13, 6485-6492.

(91) Madrigal, J. L.; Feinstein, D. L.; Dello Russo, C. Norepinephrine protects cortical neurons against microglial-induced cell death. J. Neurosci. Res. 2005, 81, 390-396.

(92) Canas, P. T.; Velly, L. J.; Labrande, C. N.; Guillet, B. A.; SautouMiranda, V.; Masmejean, F. M.; Nieoullon, A. L.; Gouin, F. M.; Bruder, N. J.; Pisano, P. S. Sevoflurane protects rat mixed cerebrocortical neuronal-glial cell cultures against transient oxygenglucose deprivation: involvement of glutamate uptake and reactive oxygen species. Anesthesiology 2006, 105, 990-998.

(93) Schubert, D.; Piasecki, D. Oxidative glutamate toxicity can be a component of the excitotoxicity cascade. J. Neurosci. 2001, 21, 74557462 .

(94) Ha, J. S.; Lee, C. S.; Maeng, J. S.; Kwon, K. S.; Park, S. S. Chronic glutamate toxicity in mouse cortical neuron culture. Brain Res. 2009, 1273, 138-143.

(95) Abdelhamid, R.; Luo, J.; Vandevrede, L.; Kundu, I.; Michalsen, B.; Litosh, V. A.; Schiefer, I. T.; Gherezghiher, T.; Yao, P.; Qin, Z.; Thatcher, G. R. Benzothiophene selective estrogen receptor modulators provide neuroprotection by a novel GPR30-dependent mechanism. ACS Chem. Neurosci. 2011, 2, 256-268. 